\title{
Ecology and management of raccoons within an intensively managed forest in the central Appalachians
}

\author{
Sheldon F. Owen \\ West Virginia University
}

Follow this and additional works at: https://researchrepository.wvu.edu/etd

\section{Recommended Citation}

Owen, Sheldon F., "Ecology and management of raccoons within an intensively managed forest in the central Appalachians" (2003). Graduate Theses, Dissertations, and Problem Reports. 1931.

https://researchrepository.wvu.edu/etd/1931

This Dissertation is protected by copyright and/or related rights. It has been brought to you by the The Research Repository @ WVU with permission from the rights-holder(s). You are free to use this Dissertation in any way that is permitted by the copyright and related rights legislation that applies to your use. For other uses you must obtain permission from the rights-holder(s) directly, unless additional rights are indicated by a Creative Commons license in the record and/ or on the work itself. This Dissertation has been accepted for inclusion in WVU Graduate Theses, Dissertations, and Problem Reports collection by an authorized administrator of The Research Repository @ WVU.

For more information, please contact researchrepository@mail.wvu.edu. 


\title{
ECOLOGY AND MANAGEMENT OF RACCOONS WITHIN AN INTENSIVELY MANAGED FOREST IN THE CENTRAL APPALACHIANS
}

\author{
By
}

\author{
SHELDON F. OWEN
}

A Dissertation Submitted to the College of Agriculture, Forestry, and Consumer Sciences

at West Virginia University

in partial fulfillment of the requirements

for the Degree

\author{
Doctor of Philosophy \\ in \\ Forest Resource Science
}

\author{
John W. Edwards, Ph.D, Chair \\ James M. Crum, Ph.D. \\ W. Mark Ford, Ph.D. \\ David W. McGill, Ph.D. \\ Petra Bohall Wood, Ph.D.
}

\section{Morgantown, West Virginia 2003}

Keywords: Baylisascaris procyonis, compositional analysis, den selection, habitat use, homerange, Procyon lotor, rabies, raccoon, timber harvesting 


\section{ABSTRACT \\ Ecology and Management of Raccoons within an Intensively Managed Forest in the Central Appalachians}

\section{Sheldon F. Owen}

The raccoon (Procyon lotor), a generalist meso-predator, is commonly found throughout the eastern United States. Many researchers have examined the ecology and spatial requirements of raccoons in agricultural and wetland areas of the mid-western and southeastern United States. However, no studies have quantitatively examined raccoon habits in the forested central Appalachians and their response to forest management. During the fall of 2000 through the spring of 2003, I monitored the spatial movements and den site selection of raccoons within an intensively managed forest.

During this period, I radio-tagged and determined spatial requirements for 30 adult raccoons (13 female; 17 male) and compared them among three spatial scales. Homerange (95\% adaptive kernel method) and core-homerange (50\%) size differed by gender but not season. Males maintained larger homeranges (394 ha) than females (244 ha). I found no gender or season specific differences in habitat selection at the homerange level and homerange composition did not differ from available habitat composition. I also found no gender or season specific differences in habitat selection within core homeranges compared to the homerange level, however habitat composition did differ between the core-homerange and $95 \%$ homerange levels. Habitat composition, as determined by the actual locations did not differ by gender, however it did differ between seasons. Habitat composition associated with active-nocturnal locations was disproportionate to the $95 \%$ homerange selection. Raccoons selected riparian areas and regeneration harvests during summer, whereas intact and diameter- limit stands were selected during fall.

I tracked 32 raccoons to 175 diurnal den sites that included cavity trees, rock dens, log piles, slash piles, and various exposed limbs. Overall, den selection differed between genders, season and among den type used. Female raccoons selected tree cavities as maternal den sites. The 62 cavity trees observed consisted of 12 tree species; of those, the seven maternal dens were in five tree species. Although I found no difference in cavity tree diameter between genders, cavity trees had larger diameters during winter than in spring and summer for both genders. I also found no difference in cavity height between genders or among seasons. Because raccoons are very adaptable and capable of using a variety of den structures, den abundance may not be the primary limiting factor to raccoon populations within intensively managed forests, at present. Nonetheless, because female raccoons selected cavities as maternal sites, the continued loss of large diameter trees without replacement in forests with 40-60 year rotations may pose a future impact to raccoon recruitment and survival.

I investigated the occurrence of raccoon roundworm (Baylisascaris procyonis) in raccoons (Procyon lotor) within my study area. I found no evidence of $B$. procyonis infection in 25 raccoons sampled by fecal floatation and necropsy methodologies. On the basis of my 25 negative cases at a $95 \%$ confidence level the estimated non-detectable maximum constant 
prevalence rate is $8 \%$. Baylisascaris procyonis has been implicated in population declines of the Allegheny woodrat (Neotoma magister) in the northeastern United States. The low prevalence of B. procyonis in an area inhabited by what is believed to be a stable population of Allegheny woodrats supports conservation measures to monitor anthropogenic activities that may increase the prevalence of B. procyonis or raccoon interaction with Allegheny woodrats.

During my study, I found $13 \%$ of all active raccoon locations to be below $800 \mathrm{~m}$ elevation and 55\% and $92 \%$ of the active locations below $900 \mathrm{~m}$ and $1000 \mathrm{~m}$ respectively. According to the stream buffer analysis, I found $63 \%$ of all active locations to be within $200 \mathrm{~m}$ of a steam and $82 \%, 92 \%$, and $98 \%$ of all active locations to be within $300 \mathrm{~m}, 400 \mathrm{~m}$, and $500 \mathrm{~m}$ respectively. Restructuring the rabies vaccination bait-drop area on my study site to include an elevational ceiling of $1000 \mathrm{~m}$ and focusing the drop zone to within $400 \mathrm{~m}$ on either stream bank to target $92 \%$ of the nocturnal activity, would effectively reduce the bait-drop area by $36 \%$, while maintaining $>70 \%$ contact with all animals. Applying these same parameters of $1000 \mathrm{~m}$ elevation and within $400 \mathrm{~m}$ of a stream would reduce the bait drop area at the county (Randolph) level by $22 \%$. 


\section{ACKNOWLEDGMENTS}

I thank USDA Forest Service Northeastern Research Station, West Virginia University, Division of Forestry, West Virginia Cooperative Fish and Wildlife Research Unit US Geological Survey, MeadWestvaco Corporation, USDA/APHIS Wildlife Services, and West Virginia Division of Natural Resources who provided financial support and equipment for this project.

I thank my major advisor, Dr. John Edwards for this opportunity and for his assistance, support, guidance, and friendship throughout this project. I would also like to thank my committee Dr. Jim Crum, Dr. Mark Ford, Dr. Dave McGill, and Dr. Petra Bohall Wood for their invaluable advice and input into this project. Thanks to Dr. Crum for additional field and laboratory assistance, advice, and ideas. I am particularly thankful to Dr. Ford and his wife, Jane Rodrigue, for field assistance and bringing back the laughter in a dark raccoon world.

I would like to thank my field technicians, Heather Brace and Justin Adams for their hard work and long hours. Without their hard work in the field, this project would not have happened. I also thank Josh Johnson, Brent Sparks, and T.J. Teter who also helped out with fieldwork.

The love, support, and prayers of my family are unending, I love and appreciate them beyond words. I also thank Sarah Cross, who edited earlier versions of these manuscripts, her constant love, support, and motivation were beyond belief and inspired me to reach this goal. 


\section{TABLE OF CONTENTS}

ABSTRACT

ACKNOWLEDGMENTS

iii

LIST OF TABLES

vii

LIST OF FIGURES

viii

INTRODUCTION, RESEARCH JUSTIFICATION, AND OBJECTIVES .............. 1

LITERATURE CITED

CHAPTER 1 -- HOMERANGE SIZE AND HABITAT SELECTED BY RACCOONS (PROCYON LOTOR) WITHIN AN INTENSIVELY MANAGED FOREST IN CENTRAL WEST VIRGINIA

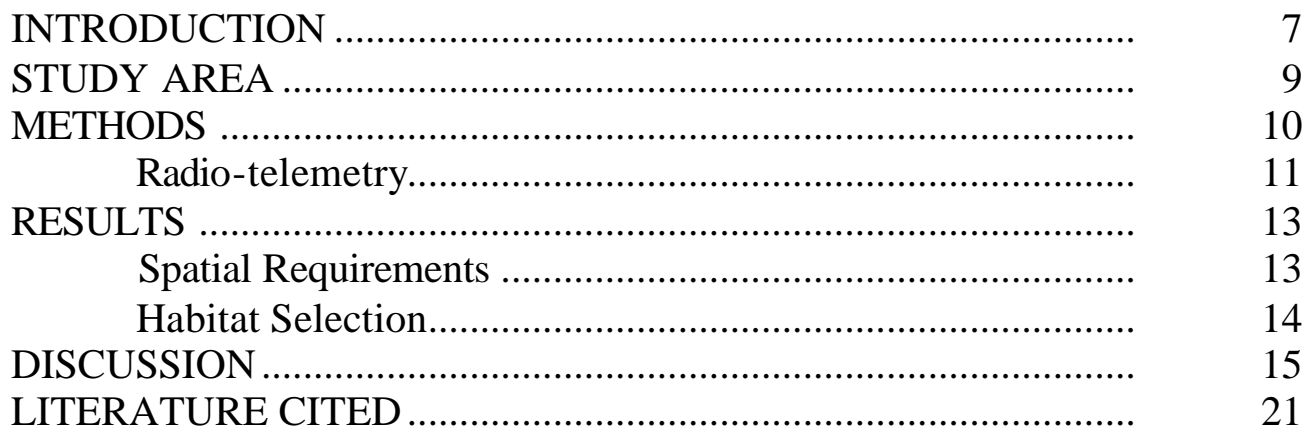

CHAPTER 2 - DEN-SITE SELECTION OF RACCOONS (PROCYON LOTOR) WITHIN AN INTENSIVELY MANAGED FOREST IN CENTRAL WEST VIRGINIA

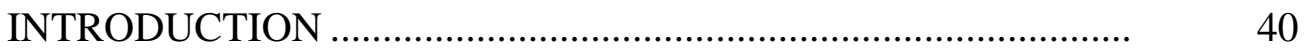

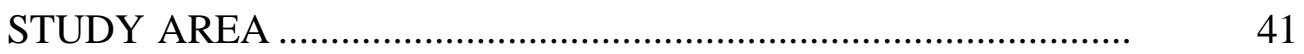

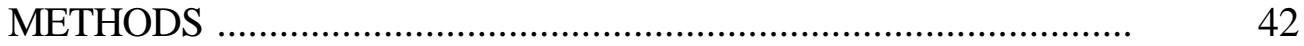

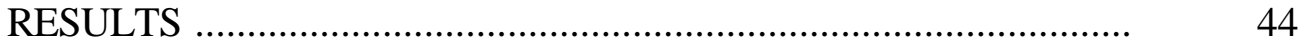

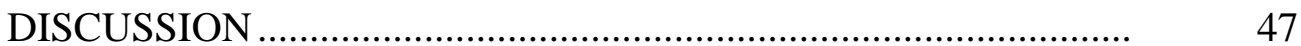

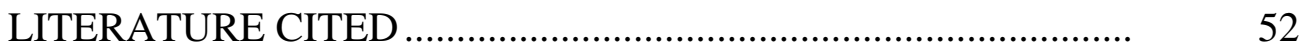

CHAPTER 3 -- OCCURRENCE OF RACCOON ROUNDWORM IN RACCOONS IN CENTRAL WEST VIRGINIA: IMPLICATIONS FOR ALLEGHENY WOODRAT CONSERVATION

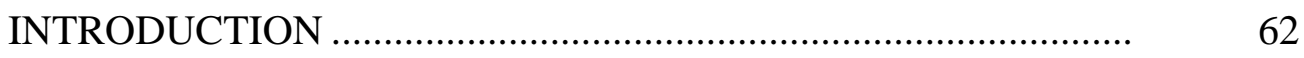

Parasite Life Cycle .......................................................... 63

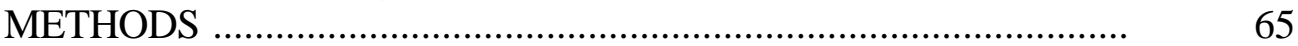




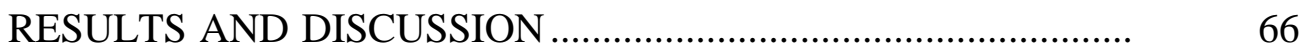

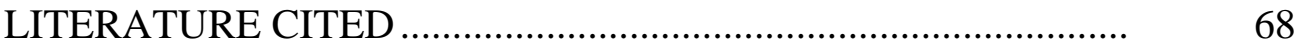

CHAPTER 4 -- RACCOON SPATIAL REQUIREMENTS AND THEIR IMPLICATIONS FOR THE APPALACHIAN RIDGE ORAL RABIES VACCINATION PROGRAM

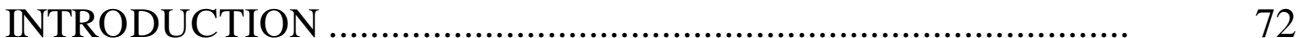

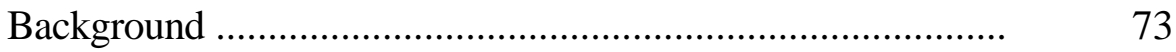

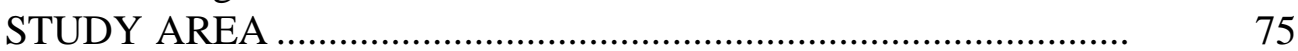

METHODS ………………………………………...........

Radio-telemetry................................................................ 76

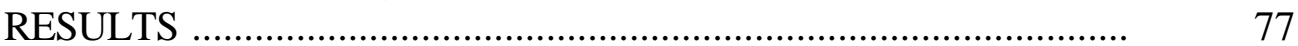

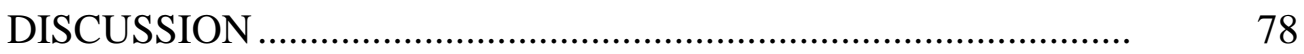

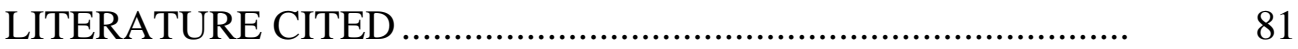

CHAPTER 5 -- CONCLUSIONS AND MANAGEMENT IMPLICATIONS.......... 88

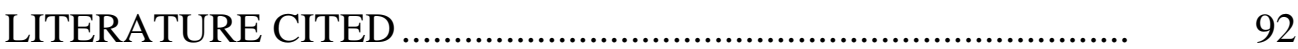




\section{LIST OF TABLES}

Table

Page

1.1 Rank ( 5 = most selected; 1 = least selected) for raccoon (Procyon lotor) habitat selection based on the comparison of the percentage of habitat associated with: 1) core homerange (50\% adaptive kernel method) and the $95 \%$ adaptive kernel method homerange estimate; 2) active raccoon locations with the $95 \%$ adaptive kernel method homerange estimate on the MeadWestvaco Wildlife and Ecosystem Research Forest, Randolph County, West Virginia, during August 2000 - March 2003.

1.2 Rank (5 = most selected; $1=$ least selected) for raccoon (Procyon lotor) habitat selection during summer and fall based on the comparison of the percentage of habitat associated with active raccoon locations with the $95 \%$ adaptive kernel method homerange estimate on the MeadWestvaco Wildlife and Ecosystem Research Forest, Randolph County, West Virginia, during August 2000 March 2003.

A.1. Summary of raccoon telemetry data on the MeadWestvaco Wildlife and Ecosystem Research Forest, Randolph County, West Virginia, during August 2000 - March 2003.

2.1. Relative frequency of diurnal den use by raccoons (Procyon lotor) among seasons on the MeadWestvaco Wildlife and Ecosystem Research Forest, Randolph County, West Virginia, during 2001 to 2002 


\section{LIST OF FIGURES}

Figure

Page

1.1. Habitat selection at three spatial scales: (1) composition of each $95 \%$ adaptive kernel method homerange to the composition of random homeranges (equal to the average homerange size) within a composite homerange derived from all locations combined; (2) corehomerange (50\% adaptive kernel method) composition to composition of the $95 \%$ adaptive kernel method homerange; (3) composition associated with the actual locations to the composition of the $95 \%$ adaptive kernel method homerange.

1.2. Percent use $( \pm \mathrm{SE})$ in the core-homerange (50\% adaptive kernel method homerange estimate) and percent available $( \pm \mathrm{SE})$ in $95 \%$ adaptive kernel method home range in each habitat type for raccoon (Procyon lotor) on the MeadWestvaco Wildlife and Ecosystem Research Forest, Randolph County, West Virginia, during August 2000 - March 2003

1.3. Percent used $( \pm \mathrm{SE})$ associated with the actual locations and percent available $( \pm \mathrm{SE})$ in $95 \%$ adaptive kernel method home range in each habitat type for raccoon (Procyon lotor) on the MeadWestvaco Wildlife and Ecosystem Research Forest, Randolph County, West Virginia, during August 2000 - March 2003.

1.4. Summer estimates for percent used $( \pm \mathrm{SE})$ associated with the actual locations and percent available $( \pm \mathrm{SE})$ in $95 \%$ adaptive kernel method home range in each habitat type for raccoon (Procyon lotor) on the MeadWestvaco Wildlife and Ecosystem Research Forest, Randolph County, West Virginia, during August 2000 - March 2003.

1.5. Fall estimates for percent used $( \pm \mathrm{SE})$ associated with the actual locations and percent available $( \pm \mathrm{SE})$ in $95 \%$ adaptive kernel method home range in each habitat type for raccoon (Procyon lotor) on the MeadWestvaco Wildlife and Ecosystem Research Forest, Randolph County, West Virginia, during August 2000 - March 2003.

1.6. Individual variation in the difference of percent use and percent available for the core-homerange and $95 \%$ adaptive kernel method for raccoon (Procyon lotor) on the MeadWestvaco Wildlife and Ecosystem Research Forest, Randolph County, West Virginia, during August 2000 - March 2003.

1.7. Individual variation in the difference of percent use and percent available for the habitat associated with the actual locations and 95\% 
adaptive kernel method for raccoon (Procyon lotor) on the MeadWestvaco Wildlife and Ecosystem Research Forest, Randolph County, West Virginia, during August 2000 - March 2003.

1.8. Summer individual variation in the difference of percent use and percent available for the habitat associated with the actual locations and $95 \%$ adaptive kernel method for raccoon (Procyon lotor) on the MeadWestvaco Wildlife and Ecosystem Research Forest, Randolph County, West Virginia, during August 2000 - March 2003.

1.9. Fall individual variation in the difference of percent use and percent available for the habitat associated with the actual locations and 95\% adaptive kernel method for raccoon (Procyon lotor) on the MeadWestvaco Wildlife and Ecosystem Research Forest, Randolph County, West Virginia, during August 2000 - March 2003.

2.1. Relative frequency of den type use of raccoons (Procyon lotor) on the MeadWestvaco Wildlife and Ecosystem Research Forest, Randolph County, West Virginia, during 2001 to 2002.

2.2. Mean diameter $( \pm \mathrm{SE})$ of cavity trees used by raccoons (Procyon lotor) on the MeadWestvaco Wildlife and Ecosystem Research Forest, Randolph County, West Virginia, during 2001 to 2002.

2.3. Mean cavity height $( \pm \mathrm{SE})$ of cavity trees used by raccoons (Procyon lotor) on the MeadWestvaco Wildlife and Ecosystem Research Forest, Randolph County, West Virginia, during 2001 to 2002.

4.1. Percentage of nocturnal activity below elevational buffers of 800 , 900, and $1000 \mathrm{~m}$ on the MeadWestvaco Wildlife and Ecosystem Research Forest, Randolph County, West Virginia, during 2001 to 2002.

4.2. Percentage of nocturnal activity within stream buffers of 200, 300, 400, and $500 \mathrm{~m}$ on the MeadWestvaco Wildlife and Ecosystem Research Forest, Randolph County, West Virginia, during 2001 to 2002

4.3. Targeted bait drop area within $300 \mathrm{~m}$ and $400 \mathrm{~m}$ of a stream and below $1000 \mathrm{~m}$ elevation on the MeadWestvaco Wildlife and Ecosystem Research Forest, Randolph County, West Virginia.

4.4. Targeted bait drop area within $400 \mathrm{~m}$ of a stream and below $1000 \mathrm{~m}$ elevation, Randolph county, West Virginia.

4.5. Area within the Allegheny Mountains greater than 1000 m elevation. 


\section{INTRODUCTION, RESEARCH JUSTIFICATION, AND OBJECTIVES}

Forest management can create habitat modifications that impact vertebrate species assemblages and interspecific interactions. Increased fragmentation and edge, along with other structural changes brought about by forestry practices, may enhance the abundance and predatory efficiency of medium-sized mammalian predators (Heske et al. 2001). Greater availability of suitable habitat coupled with the extirpation of large mammalian predators [mountain lions (Puma concolor) and gray wolves (Canis lupus)] has led to an increase in medium-sized predators such as opossums (Didelphis virginianus), raccoons (Procyon lotor), red foxes (Vulpes vulpes), gray foxes (Urocyon cineroargenteus), and coyotes (Canis latrans). In fact, increased depredation has been implicated for declines in avian nesting success and productivity in agricultural or mixed agriculture-forested landscapes in eastern North America (Heske et al. 2001, Rollins and Carroll 2001). However, in the heavily forested central and southern Appalachians, relations between meso-predators and their habitat remain poorly documented and are incompletely understood. Our understanding of predator spatial ecology as modified by altered landscapes has been based on data from largely agricultural areas of the Midwest or Southeast, which may be disparate from relations observed in the Appalachians. Raccoons, because of their known nest-predating habits (Heske et al. 2001, Rollins and Carroll 2001), can be viewed as a general model for medium-sized predators and therefore can serve as subjects for improving our comprehension of spatial ecology as it is affected by habitat modifications.

The raccoon is commonly found throughout the continental United States (Lotze and Anderson 1979) in habitats that include farmlands, wetlands, forested environment s, parks, suburban housing districts, and cities (Johnson 1970, Lotze and Anderson 1979). Prized by 
hunters and trappers for sport hunting, pelts, and even food, raccoons have also been the focus of many ecological studies regarding their habits, habitats, and diseases (Johnson 1970, Lotze and Anderson 1979, Kaufmann 1982). Most research, however, has been conducted in wetlands and agricultural areas in the Southeast and Midwest where raccoon populations are reaching nuisance status. This raccoon research has come in response to problems created by raccoon overabundance such as crop damage, disease outbreaks, nest depredation, and wildlife-human interactions in urban settings where animals destroy property, prey on songbirds, and pose the threat of disease transmission to other wildlife and humans. There is, however, little information on raccoon ecology in the rural forested habitats of the central Appalachian Region and virtually none in regard to forest management.

The Appalachian Cooperative Grouse Research Project initiated in 1996 has sought to investigate the population dynamics and ecology of ruffed grouse (Bonasa umbellus) in the southern and central Appalachian Mountains. One limiting factor to ruffed grouse reproductive success is the threat of depredation on the nests and chicks of these ground-nesting birds. As omnivorous predators that opportunistically prey on ground-nesting birds (Hewitt et al. 2001), raccoons, where abundant, could potentially impact not only grouse populations but also many ground or shrub layer nesting songbirds.

Increased rates of nest depredation and reduced breeding success have been related to habitat fragmentation (Faaborg et al. 1995). However, the evidence for adverse effects of habitat fragmentation and edge is decidedly mixed (Heske et al. 2001). Depredation rates are more common along forest-agriculture edges than forest-forest mosaics (Faaborg et al. 1995, Heske et al. 2001). Highly fragmented landscapes with little forest cover have greater nest depredation rates along edges than in interior habitat, whereas mostly forested landscapes have lesser rates of 
nest depredation in general (Heske et al. 2001). Rates of depredation also may be altered by compounding effects of forest fragmentation and over-browsing impacts of white-tailed deer (Odocoileus virginianus). Local habitat fragmentation coupled with the landscape mosaic may further impact depredation rates via the movements of medium-sized predators. Thus, nest depredation rates can be a product of factors acting at various spatial scales, from microhabitat to landscape (Tewksbury et al. 1998, Heske et al. 2001).

Raccoon habitat data combined with on-going songbird, ruffed grouse, northern flying squirrel (Glaucomys sabrinus), and recently completed Allegheny woodrat (Neotoma magister) research on my study area will give insight to predator-prey relations and aid in adaptive management for prey species. Further investigation also can be applied to the ongoing edge effect and nest depredation debate associated with fragmented landscapes.

Raccoons are vectors for rabies and a major public health concern because of increased interaction with humans and domestic pets. A raccoon rabies epizootic began in the midAtlantic states in 1977 and positive rabies cases peaked in 1983 (Hubbard 1985, Torrence et al. 1992). The number of reported cases declined thereafter; however, the geographic distribution of positive rabies cases has increased (Torrence et al. 1992). The first rabies case in West Virginia of this epizootic was reported in 1977 (Hubbard 1985). Since that time the epizootic has spread westward across West Virginia; though, the rate of spread has slowed somewhat crossing the Allegheny Mountains. Raccoon movements as related to the spread of rabies are of considerable concern and therefore knowledge of raccoon population densities and spatial requirements will influence rabies management.

There is little information of the densities and habits of raccoons in the central Appalachians. With the demons trated need for increased knowledge to properly manage these 
populations, I undertook a study of raccoon ecology in the central Appalachian Mountain Region. Information gathered will help predict threats, such as nest depredation and den displacement, to the ruffed grouse, songbird, Allegheny woodrat, and northern flying squirrel populations, and increase the understanding of raccoon populations and their potential disease threats in the central Appalachians. My study objectives were to:

(1) determine the spatial requirements of raccoons in an intensively managed Appalachian forest;

(2) monitor the den-site selection of raccoons within this intensively managed Appalachian forest;

(3) test fecal samples to identify raccoon parasites and determine their ecological and management implications; and

(4) relate spatial movements to the ongoing oral rabies vaccination program along with contact and rabies virus spread potential within the Allegheny Mountains.

\section{LITERATURE CITED}

Faaborg, J., M. C. Brittingham, T. M. Donovan, and J. Blake. 1995. Habitat fragmentation in the temperate zone. Pages 357-380 in T. E. Martin and D. M. Finch, editors. Ecology and management of Neotropical migratory birds. Oxford University, New York, New York, USA.

Heske, E. J., S. K. Robinson, and J. D. Brawn. 2001. Nest predation and neotropical migrant songbirds: piecing together the fragments. Wildlife Society Bulletin. 29:52-61.

Hewitt, D. G., D. M. Keppie, and D. F. Stauffer. 2001. Predation effects on forest grouse recruitment. Wildlife Society Bulletin. 29:16-23. 
Hubbard, D. R. 1985. A descriptive epidemiological study of raccoon rabies in a rural environment. Journal of Wildlife Diseases. 21:105-110.

Johnson, S. A. 1970. Biology of the raccoon (Procyon lotor) in Alabama. Agricultural Experiment Station Auburn University Bulletin 402. 148 pp.

Kaufmann, J. H. 1982. Raccoon and Allies. Pages 567-585 in J. A. Chapman and G. A. Feldhamer, editors. Wild mammals of North America. John Hopkins University Press, Baltimore, Maryland. 1147pp.

Lotze, J. H., and S. Anderson. 1979. Procyon lotor. Mammalian Species. 119:1-8.

Rollins, D., and J. P. Carroll. 2001. Impacts of predation on northern bobwhite and scaled quail. Wildlife Society Bulletin. 29:39-51.

Tewksbury, J. J., S. J. Hejl, and T. E. Martin. 1998. Breeding productivity does not decline with increasing fragmentation in a western landscape. Ecology. 79:2890-2903.

Torrence, M. E., S. R. Jenkins, and L. T. Glickman. 1992. Epidemiology of raccoon rabies in Virginia, 1984 to 1989. Journal of Wildlife Diseases. 28:369-376. 


\title{
Chapter 1
}

\section{Homerange size and habitat selection by raccoons (Procyon lotor) within an intensively managed forest in central West Virginia}

Sheldon F. Owen, Wildlife and Fisheries Resources Program, Division of Forestry, Box 6125, West Virginia University, Morgantown, WV 26506-6125, USA

John W. Edwards, Wildlife and Fisheries Resources Program, Division of Forestry, Box 6125, West Virginia University, Morgantown, WV 26506-6125, USA

W. Mark Ford, USDA Forest Service, Northeastern Forest Experiment Station, Fernow Experimental Forest, Box 404, Parsons, WV 26287, USA

Petra Bohall Wood, West Virginia Cooperative Fish and Wildlife Research Unit US Geological Survey and West Virginia University, Box 6125, Morgantown, WV 26506-6125, USA

\begin{abstract}
As part of a raccoon (Procyon lotor) ecology study in intensively managed hardwood forest in the Allegheny Mountains of central West Virginia, we radio-tagged and determined spatial requirements for 30 adult raccoons (13 female; 17 male). Homerange (95\% adaptive kernel method) and core-homerange (50\%) size differed between genders with males $(95 \%=$ 394 ha; $50 \%=69.9$ ha) maintaining larger homeranges than females $(95 \%=244$ ha; $50 \%=26.6$ ha). Homerange and core-homerange size did not differ between seasons. We found no gender or season specific differences in habitat selection at the homerange level and homerange composition did not differ from available habitat composition. We also found no gender or season specific differences in habitat selection within core homeranges compared to the homerange level, however habitat composition did differ between the core-homerange and $95 \%$
\end{abstract}


homerange levels. Habitat composition, as determined by the estimated active locations did not differ by gender, however it did differ between seasons. Habitat composition associated with active locations was disproportionate to the $95 \%$ homerange selection. Raccoons selected riparian areas and regeneration harvests during summer, whereas intact and diameter-limit stands were selected during fall.

\section{INTRODUCTION}

Forest management can modify habitats, resulting in altered vertebrate species assemblages and interspecific interactions. Increased fragmentation and edge, along with other structural changes brought about by forestry practices, may enhance the abundance and predatory efficiency of medium-sized mammalian predators (Heske et al. 2001). The increase in available habitat coupled with the extirpation of large mammalian predators such as mountain lions (Puma concolor) and wolves (Canis lupus and C. rufus) has led to an increase in opossums (Didelphis virginianus), raccoons (Procyon lotor), red foxes (Vulpes vulpes), gray foxes (Urocyon cineroargenteus), and coyotes (Canis latrans). Increased depredation has been implicated for declines in avian nesting success and productivity in agricultural or mixed agriculture-forested landscapes in eastern North America (Heske et al. 2001, Rollins and Carroll 2001). Our understanding of predators and habitat associations as modified by altered landscapes has been based on data from largely agricultural areas of the Midwest or Southeast, which may be disparate from relations observed in other areas. In the heavily forested central and southern Appalachians, the relations between meso-predators and their associated habitats remain poorly documented and are incompletely understood. Raccoons, because of their known nest-predating habits (Heske et al. 2001, Rollins and Carroll 2001) and ability to respond to habitat disturbance at multiple spatial scales (Pedlar et al. 1997, Chamberlain et al. 2003), can be 
viewed as a general model for medium-sized predators and therefore can serve as subjects for improving our comprehension of habitat associations as they are affected by forest management.

In the central Appalachians, extensive timber harvesting in the early 1900's and again since the early 1980's has produced a complex landscape of stands $\leq 80$ years old (McGarigal and Fraser, 1984; Rosenberg et al., 1988; DiGiovanni, 1990), with virtually no remaining oldgrowth. An average of 5.4 million $\mathrm{m}^{3}$ of hardwood lumber is harvested annually from West Virginia (DiGiovanni, 1990), nearly half of the 1910 peak when West Virginia led the nation in harvest. Unlike the turn of the $20^{\text {th }}$ Century pulse, the current harvest level occurs annually and over an extended time-period, so ecological data on forest dwelling species such as the raccoon is critical to assess the impact of this continuing landscape event on spatial- and ecological requirements of meso-predators.

Raccoons are considered a generalist species, occupying a range of habitats including farmlands, wetlands, forested environments, parks, suburban housing districts, and cities (Johnson 1970, Lotze and Anderson 1979). Raccoons have been the focus of many ecological studies regarding their habits, habitats, and disease associations (Johnson 1970, Lotze and Anderson 1979, Kaufmann 1982). Most research, however, has been conducted in wetlands and agricultural areas in the Southeast and Midwest where raccoon populations are reaching nuisance status. There is, however, little information on raccoon ecology and spatial requirements in the rural forested habitats of the central Appalachian Region and virtually none dealing with raccoons and forest management within this system.

With the demonstrated need for increased knowledge detailing the impacts of forest management on meso-predator populations, we undertook a raccoon ecology study in the central Appalachian Mountain Region. Information gathered will increase the understanding of raccoon 
spatial requirements and habitat associations in respect to intensive forest management within the mostly forested central Appalachians. Our objective was to describe the spatial requirements and habitat selection of raccoons at three spatial scales within an intensively managed hardwood forest. Second, we examined if gender and seasonal differences existed in spatial requirements and habitat selection.

\section{STUDY AREA}

Our study was conducted on the 3630 ha MeadWestvaco Wildlife and Ecosystem Research Forest (MWERF) located in the Allegheny Mountain and Plateau physiographic subprovince in Randolph County, West Virginia. The MWERF is an intensively managed forest dedicated to the study of the interaction of industrial forestry with Appalachian ecosystems. Elevations range from $700 \mathrm{~m}$ to $1200 \mathrm{~m}$ with steep side-slope mountains, broad ridge tops, and narrow valleys. The underlying geologic material is primarily Pottsville series shale and sandstone, along with limestone (Fenneman 1938). Emergent rock outcrops formed along mountain ridgelines as shale eroded and the more resistant sandstone remained. The climate is cool and moist, with a growing season of 150 days (Smith 1995). The MWERF is a second- and third-growth Allegheny-northern hardwood forest dominated by black cherry (Prunus serotina), sugar maple (Acer saccharum), red maple (A. rubrum), yellow birch (Betula alleghaniensis), American beech (Fagus grandifolia), and northern red oak (Quercus rubra) except high elevations that are characterized by red spruce (Picea rubens) and Eastern hemlock (Tsuga canadensis) communities. Riparian areas are characterized by the aforementioned tree species and thickets of rosebay rhododendron (Rhododendron maximum).

We delineated six vegetation types on the forest: (1) intact second- and third-growth forest, (2) riparian areas, (3) diameter- limit harvests, (4) regeneration harvests (including 
deferment harvests and clearcuts), (5) roads, and (6) open/nonforest areas. Intact forests were 70-80 year old second- and third-growth stands with no mechanical disturbance since stand initiation, whereas diameter- limit stands had approximately $50 \%$ of the basal area removed during repeated harvests over the past two decades. Riparian areas were intact-forested areas found along perennial and intermittent streams. Locally, deferment and clearcut harvests regenerate shade intolerant forest communities and therefore we grouped them into a regeneration harvest category. Deferment and clearcut harvests were similar in silvicultural function, however, approximately $10 \%$ of the initial basal area was left on site in deferment cuts whereas all trees $>2.5 \mathrm{~cm}$ diameter at breast height $(\mathrm{dbh})$ were removed in clearcuts. Most deferment and clearcut stands were $0-10$ years of age.

\section{METHODS}

We used $38 \times 38 \times 105 \mathrm{~cm}$ and $25 \times 25 \times 80 \mathrm{~cm}$ cage traps $\left(\right.$ Havahart ${ }^{\circledR}{ }^{1}$, Woodstream Corporation, Lititz, PA) baited with sardines, marshmallows, and forms of rancid meats to livetrap raccoons. We chemically immobilized trapped raccoons with $30 \mathrm{mg} / \mathrm{kg}$ Ketamine plus 4 $\mathrm{mg} / \mathrm{kg}$ Xylazine (Kreeger 1999). Yohimbine $(0.15 \mathrm{mg} / \mathrm{kg})$ was used as an antagonist to Xylazine. Once immobilized, age (juvenile or adult) and gender were determined based on external characteristics (Johnson 1970, Kramer et al. 1999). Each individual was ear-tagged with a uniquely numbered Jiffy size 3 aluminum tag (National Band and Tag Co., Newport, KY) and weighed. We also recorded total length, ear length, and hind-foot length measurements. Adult males and females were equipped with mortality sensitive radio collars (Advanced Telemetry Systems, Asanti, MN; AVM Instrument Company, Ltd., Colfax, CA). Radio collars weighed

\footnotetext{
${ }^{1}$ Use of trade names does not imply endorsement by the federal government.
} 
approximately 70 grams and had a battery life of 18 months. We only tagged adults to minimize the chance of dispersing sub-adults leaving the study area.

\section{Radio Telemetry}

To determine spatial movements and habitat selection, we monitored radio-tagged individuals with Wildlife Materials TRX-2000S receivers (Wildlife Materials Inc., Carbondale, IL), and 3-element Yagi antennas to determine spatial locations. Animals were monitored $=3$ nights a week during summer (May - August) and fall (September - December). We conducted nocturnal triangulation (simultaneous and individual observer) from approximately 1 hour after sunset until 1 hour after sunrise. Based on expected homerange size and speed of travel by raccoons, bearings were taken every 3 hours to reduce possible autocorrelation among telemetry locations (White and Garrott 1990). To reduce telemetry error, we recorded telemetry bearings from as near the animal as possible, and minimized the temporal interval ( $<5 \mathrm{~min})$ between bearings. We estimated the error associated with our animal locations following the protocol outlined by White and Garrott (1990). We estimated the average bearing error by determining the difference between bearings taken on transmitters hidden in the field and the true bearings from the telemetry station to the location of the transmitter. We calculated the average error polygon as the average size of the polygon created by the error arcs of 2 bearings taken on a transmitter from 2 telemetry stations (Hurst and Lacki 1999). Only raccoons with >30 locations were retained in our data to determine homerange and habitat selection.

To determine UTM coordinates of the estimated locations, we entered the UTM coordinates of known telemetry stations and locational bearings into program LOCATE. The LOCATE UTM coordinates then were entered into the Animal Movement Analysis Extension (Hooge and Eichenlaub 1997) in ArcView® (Environmental Systems Research Institute, 
Redlands, California) where we determined core homerange size using 50\% Adaptive Kernel Method (AKM) and the 95\% AKM homerange estimates. We compared homerange size and habitat selection estimates for spring/summer (April-August) and fall/winter (SeptemberJanuary) time-periods, and for male versus female use patterns. We compared homerange size to determine season- and gender-specific differences using a three-way ANOVA.

We developed GIS vegetation types based on existing forest inventory stand information provided by MeadWestvaco. Spatial Analyst was used to determine proportions of vegetation types associated with locations, core-homerange, and $95 \%$ homerange polygons. The proportions of vegetation types were calculated as the amount of each vegetation type found within each homerange estimate. Proportions of vegetation types associated with the active locations were determined by identifying the vegetation type in which the location was found for each active location used in generating the homerange estimates. We investigated habitat use at three spatial scales, approximately based on the spatial scales defined by Johnson (1980) (Fig. 1). First, we compared the composition of each 95\% AKM homerange to the composition of random homeranges (equal to the average homerange size) within a composite homerange derived from pooled locations. We then compared core-homerange (50\% AKM) composition to the composition of the 95\% AKM homerange. Finally, we compared the composition associated with the actual locations to the composition of the 95\% AKM homerange.

We compared habitat selection using compositional analysis (Aebischer et al., 1993). Within compositional analysis, if a particular vegetation type was considered available but unused, we replaced the missing value with 0.0001 (Aebischer et al., 1993). Habitat composition estimates were compared using MANOVA to determine season- and gender-specific differences. If significant differences were detected then a ranking matrix of $t$-tests was performed to 
examine habitat preference (Aebischer et al. 1993). We constructed a residual matrix from the matrix of log-ratio differences and computed Wilks' $\lambda$ to test for randomization among habitat use. We then constructed a matrix ranking vegetation types and assigned ranks to each vegetation type in order of use. We used $t$-tests to assess differences among ve getation type ranks (Aebischer et al., 1993). To determine importance of vegetation associations used based on variability among individuals within each vegetation type, we subtracted the proportion of vegetation type available from the proportion of vegetation type selected according to Thomas and Taylor (1990).

\section{RESULTS}

\section{Spatial requirements}

We radio-tagged and monitored 42 adult raccoons from fall 2000 through spring 2002. We obtained sufficient locations (>30 locations) from 13 female (5 fall; 8 summer) and 17 male (6 fall; 11 summer) individuals to compare homerange size and habitat use differences (Appendix A). Mean female homerange size was 244 ha (range 104.9-581.8, SE = 38.0). Mean male homerange size was 394 ha (range 140.1-701.5, SE =40.7). Mean homerange size differed among years $(F=5.66, d f=1, P=0.025)$ however, there were no significant interactions between year and any other variable so we blocked by year. Mean homerange size differed between gender $(F=8.76, \mathrm{df}=1, P=0.007)$ but not seasons $(F=0.05, d f=1, P=0.826)$ and there was no interaction between gender and season $(F=0.07, d f=1, P=0.797)$. After testing all individuals who recorded telemetry bearings, we calculated the telemetry bearing error to be $\pm 2.3^{\circ}$ and the error polygon to be 0.18 ha.

Female core-homerange (mean 26.6 ha; range 6.5-63.4; $\mathrm{SE}=4.8)$ was smaller than $(F=$ 5.72, $d f=1, P=0.025$ ) male core-homerange (mean 65.9 ha; range 16.6-183.38; $\mathrm{SE}=13.8$ ). 
We found no difference between seasons $(F=0.05, d f=1, P=0.830)$, years $(F=0.56, d f=1, P$ $=0.468)$, and no interaction between gender and season $(F=0.23, d f=1, P=0.638)$.

\section{Habitat selection}

We found no gender- or season-specific differences in habitat composition between the 95\% homerange and random homeranges $(P>0.10)$. Also, habitat composition of $95 \%$ homeranges did not differ from habitat composition of random homeranges $(F=1.56, d f=5, P=$ 0.207). Although not significant, habitat selection (ranked in order of selection) was diameterlimit harvest $>$ regeneration harvests $>$ open areas $>$ roads $>$ riparian areas $>$ intact forest.

We found no gender- or season-specific differences in habitat composition between core homeranges and 95\% homeranges $(P>0.10)$. However, habitat composition of core homeranges differed from that of $95 \%$ homeranges $(F=2.94, d f=5, P=0.032)$. Habitat selection ranked: riparian areas $>$ intact forest $>$ roads $>$ diameter-limit harvests $>$ open areas $>$ regeneration harvests (Table 1; Fig. 2).

We found no gender-specific difference in vegetation types associated with active locations and habitat composition of the $95 \%$ homerange $(F=2.02, d f=6, P=0.118)$. However, we detected a seasonal difference in vegetation associated with active locations and 95\% homerange composition $(F=4.07, d f=5, P=0.010)$. Summer habitat selection ranked: riparian areas $>$ regeneration harvests $>$ intact forest $>$ diameter-limit harvests $>$ open areas $>$ roads (Table 2; Fig. 4), whereas fall habitat selection ranked: intact forest > diameter-limit harvests $>$ regeneration harvests $>$ riparian areas $>$ open areas $>$ roads (Table 2; Fig. 5). Overall habitat composition differed between active locations and composition of the $95 \%$ homerange $(F$ $=8.53, d f=5, P<0.0001)$. Raccoon habitat composition between active locations and $95 \%$ 
homerange ranked in order of selection was intact forest $>$ regeneration harvests > riparian areas > diameter-limit harvests > open areas > roads (Table 1; Fig. 3).

Comparison of proportion of habitat used verses proportion available between the core and 95\% homeranges (Fig. 6) indicated minimal habitat preference based on variation among individuals. Furthermore, comparison of proportion of vegetation types associated with the active locations and $95 \%$ homerange indicated minimal habitat selection based on variation among individuals (Fig. 7). Also, the proportion of vegetation types associated with active locations and 95\% homerange compared between seasons [summer (Fig. 8) and fall (Fig. 9)] indicated minimal habitat preference.

\section{DISCUSSION}

Our homerange estimates are somewhat larger than estimates reported for raccoons from the southeastern and mid-western United States (Johnson 1970, Lotze and Anderson 1979, Gehrt and Fritzell 1997). The majority of these studies have been conducted in agricultural, bottomland hardwood, and wetland habitats. The central Appalachian region is a mostly forested (80\%) upland ecosystem that is topographically, structurally, and vegetatively different from the bottomland hardwoods and wetland areas of the Southeast. Habitat quality for raccoons in the high Allegheny Mountain region of West Virginia is rated poor to fair (Rogers 2000). Moreover, the raccoon rabies epizootic advance west of the Allegheny Mountains in the past five years may have depressed raccoon populations. Poor quality habitats and the patchy distribution of resources may cause, in part, the increase in homerange area required to meet energetic demands. Raccoons also may increase homerange size in the presence of low raccoon densities as suggested by Ellis (1964). Raccoon homerange estimates vary from 5.6 ha in urban Ohio (Hoffman and Gottschang 1977) to 4500 ha in the prairies of North Dakota (Fritzell 1978). 
Recent homerange estimates in managed pine systems in Mississippi reported homerange estimates of 153 ha for females and 244 ha for males (Chamberlain et al. 2003). Typical homerange estimates reported in the literature range from 20 to 300 ha (Stuewer 1943, Ellis 1954, Johnson 1970, Urban 1970, Pedlar et al. 1997).

Estimates of raccoon homerange also differ according to season (Fritzell 1978), gender (Ghert and Fritzell 1997), habitat (Fritzell 1978), and harvest pressure (Glueck et al. 1988). Similar to other studies, we found male homeranges to be larger than females. This difference is often attributed to the male raccoon's promiscuous or polygamous mating system whereby males travel greater distances in search of receptive females (Stuewer 1943, Johnson 1970, Fritzell 1978). Low raccoon densities within the high elevations of the central Allegheny Mountains may further exaggerate this increase in male homerange. Sexual dimorphism in body size also may provide causation for larger male homeranges. Similar to other findings, male raccoons on our study area were $10-20 \%$ larger than females, which may require them to cover greater area to meet energetic demands. Generally, males maintain larger homeranges than females as reported by Gehrt and Fritzell (1997) in southern Texas and Chamberlain et al. (2001) in central Mississippi. Females probably must maintain smaller homeranges, particularly during and after the parturition period, to remain close to their maternal den and offspring. Moreover, we found female raccoons without litters still maintained smaller homeranges than males. Once the young are old enough to travel greater distances, the female and young expand their homerange; therefore late summer and fall spatial requirements may differ from the maternal period movements as indicated by Chamberlain et al. (2003).

Core-homerange areas represent concentrated use within homeranges that frequently contain sites critical to survival including dens or selected foraging resources (Ewer 1973, 
Chamberlain et al. 2003). Observed core-homerange size was larger for males than females. Generally, female core-homeranges were centered on the maternal cavity tree particularly during the summer period (Chapter 2). Although male core homeranges included some frequently used den sites, these sites were not used more than expected based on den sites within the larger homerange. Within core-homeranges, raccoons selected riparian habitats and intact forests. Proximity to water has long been considered a limiting factor to raccoon abundance. During the summer, intact forests along riparian areas provide cooler environments for denning and moist areas for food resources such as amphibians, fish, and invertebrates (Johnson 1970, Lotze and Anderson 1979). Away from streams, intact forest canopies provide cover and cooler temperatures for amphibians and invertebrates within the litter layer along with cool, moist environs for hypogeal fungi, all of which account for significant proportions of the raccoon diet (Johnson 1970, Lotze and Anderson 1979). Black cherry, oaks, and American beech are common tree species within both the riparian and intact forests; cherry provides valuable soft mast during late summer; whereas, oaks and beech, provide valuable hard mast during fall. Johnson (1980) suggests four spatial scales at which habitats are selected. Although ultimately the scale at which raccoons select habitats is unknown (Chamberlain et al. 2002), raccoons do select habitat variables at multiple spatial scales (Pedler et al. 1997, Dijak and Thompson 2000). At the finer/smaller scales (locations and core homerange), we found raccoons selected intact forest, regeneration harvested stands, and riparian areas; whereas at the 95\% homerange scale riparian and intact forests were least selected (although not significant). Furthermore, the most selected vegetation types within core areas were riparian and intact forests while regeneration harvest was least selected. Intact forest and regeneration harvests were the most selected habitats associated with active locations. These selections, at the mid- and micro- 
scale, indicate valuable habitat resources that may have been underestimated by broad spatial scale analysis alone.

As generalists, raccoons exhibit a diverse diet and show an ability to quickly respond to temporal and spatial changes in food resources. Because of these capabilities, raccoons can use a variety of habitat conditions and types. The current and past forest management practices conducted on the MWERF have produced a shifting mosaic of vegetation types, all of which provide foraging resources used by raccoons on a seasonal basis. Intact forest stands consist of hard mast producing species including red oak and American beech, both of which are valuable fall producers. Black cherry is also abundant within these forest stands producing soft mast in summer. Regeneration harvests ( $>3$ years old) provide patches of soft mast producing Rubus spp, particularly during summer. Pin cherry (Prunus pennsylvanica) can be readily found along roadways and within regeneration harvests providing abundant soft mast in summer.

Overall, the top four selected habitats associated with active locations were intact forests, regeneration harvests, riparian areas, and diameter- limit harvest. However, these rankings changed by season. During the summer, the most selected habitats were riparian areas and regeneration harvests. The riparian areas are intact forests where logging has been excluded, often termed riparian management zones (RMZ), resulting in larger diameter trees, many with large cavities. Cavity tree use, particularly by female raccoons, may help explain the selection of this vegetation type. Likewise, these riparian areas provide access to free water required by raccoons. Raccoons are commonly associated with water and their movements are considered to be restricted by proximity to free water (Johnson 1970, Lotze and Anderson 1979, Kaufman 1982). Accordingly, we found $63 \%$ of all foraging locations to be within $200 \mathrm{~m}$ of a stream, $82 \%$ to be within $300 \mathrm{~m}$, and $92 \%$ to be within $400 \mathrm{~m}$ of a stream. Although the $300 \mathrm{~m}$ and 400 
m buffers contained $82 \%$ and $92 \%$ of all active locations respectively, all transmittered animals used these areas at some point. Current MWERF forest management practices include leaving uncut riparian management zones (RMZ) along streams. These RMZ's not only provide potential for future large-diameter cavity trees for maternal raccoon den sites, but also provide habitat for various other vertebrate and invertebrate species.

Raccoons also selected regeneration areas that contained soft mast produced by Rubus spp. and Vaccinium during the summer months. However, raccoons shifted to upland intact and diameter-limit stands in fall, where hard mast was produced. Intensive forest management within the central Appalachians ultimately creates a conundrum for raccoon management. The MWERF is managed on 20-80 year cutting intensity levels where mature forests eventually will comprise only a small portion of the area. Increased reductions in large diameter trees may impact raccoon recruitment due to loss of suitable maternal cavities (Chapter 2) especially in stands on 20-40 year rotations. However, early successional stands in association with mature second- or third-growth forests provide a mosaic of habitats resulting in a spatial and temporal dynamic of foraging resources. Coincidently, regeneration harvests can produce seasonal foods on a temporary basis (3-10 years) while ensuring the regeneration of soft mast producing, shade intolerant tree species that have the potential to develop future large-diameter cavity trees. Similarly, intact upland forest stands with larger diameter trees while potentially providing cavity trees and hard mast during fall months, may be of limited quality in summer. Forest management that combines the retention of large diameter overstory trees with intermediate thinnings to release the understory may meet foraging requirements during the summer while also providing suitable cavity trees. 
Among the harvest strategies used in West Virginia forests, approximately $80 \%$ are diameter-limit harvests (Fajvan et al. 1998). Although the diameter-limit harvest is a common technique used on the MWERF and throughout the central Appalachians on private lands, the quality of the residual stand and provisions for its adequate regeneration are rarely considered. Repeated diameter-limit harvests, without regard to species composition, will shift forest composition to shade-tolerant species as well as degrade stand quality (Nyland 1996). Reduction in hard mast producing species (i.e., Quercus spp.) resulting from diameter-limit harvests will eliminate a significant food source during fall and winter, further limiting food resources and raccoon abundance. Alternative treatments such as commercial crown thinning or improvement cuttings could produce similar solid wood production while maintaining quality habitat for raccoons and other wildlife species. An uneven-aged regeneration method, such as single-tree selection (Smith 1995), that leaves certain stocking levels in all size classes also may produce quality timber while providing cavity trees and promoting mast producing tree species. However, there are concerns over difficulty of application and its delayed tendency to result in a shade-tolerant, mast-poor forest with less favorable wildlife attributes (Smith 1995).

Because raccoons are a generalist species and capable of adapting to both wide ranges in natural and anthropogenic changes within the environment, raccoons have been successful in expanding their range and increasing numbers in some areas to nuisance status. Factors such as food availability, vegetative structure, proximity to water, and mate distribution may impact seasonal movements of raccoons (Johnson 1970, Edres and Smith 1993). Habitat quality changes throughout the year with respect to food, cover, and presence of water, and thus may influence spatial activity. Raccoons are known nest predators and during the spring and early summer may alter their movements and use habitats that provide optimal prey exposure or 
abundance. Urban (1970) noted that raccoons shift habitat use patterns during the waterfowl nesting period in northern Ohio. This indicates that raccoons alter movements within their homerange, but will not expand existing territories for a specific prey source. Likewise, as the waterfowl nesting season ends and that particular food source disappears, raccoons may reallocate foraging efforts to different areas within their homerange. Therefore, as other food items such as hard and soft mast become available/abundant, movements may indicate a shift to different food resources. However, seasonal changes in movement patterns within a mostly forested system may not be easily explained due to the dispersion of available resources.

\section{Acknowledgments}

Funding was provided by USDA Forest Service Northeastern Research Station, Division of Forestry, West Virginia University, WV Cooperative Fish and Wildlife Research Unit US Geological Survey, MeadWestvaco Corporation, USDA/APHIS Wildlife Services, and West Virginia Division of Natural Resources. We would like to thank our field technicians, H. Brace and J. Adams for their hard work and long hours. We also thank J. Johnson, J. Rodrique, and J. Crum for field and laboratory assistance and G. Seidel for statistical guidance.

\section{Literature Cited}

Aebiescher, N. J., P. A. Robertson, and R. E. Kenward. 1993. Compositional analysis of habitat use from animal radio-tracking data. Ecology. 74:1313-1325.

Chamberlain, M. J., M. L. Conner, and B. D. Leopold. 2002. Seasonal habitat selection by raccoons (Procyon lotor) in intensively managed pine forests of central Mississippi. American Midland Naturalist. 147:102-108.

Chamberlain, M. J., M. L. Conner, B. D. Leopold, and K. M. Hodges. 2003. Space use and 
multi-scale habitat selection of adult raccoons in central Mississippi. Journal of Wildlife Management. 67:334-340.

DiGiovanni, D. M. 1990. Forest Statistics for West Virginia - 1975-1980. Northeastern Forest Experiment Station. Resource Bulletin NE-114.

Dijak, W. D., and F. R. Thompson, III. 2000. Landscape and edge effects on the distribution of mammalian predators in Missouri. Journal of Wildlife Management. 64:209-216.

Dorney, R. S. 1954. Ecology of marsh raccoons. Journal of Wildlife Management. 18:217225.

Ellis, R. J. 1964. Tracking raccoons by radio. Journal of Wildlife Management. 28:363-368.

Endres, K. M., and W. P. Smith. 1993. Influence of age, sex, season, and availability on den selection by raccoons within the central basin of Tennessee. American Midland Naturalist. 129:116-131.

Ewer, R. F. 1973. The Carnivores. Cornell University Press, Ithaca, New York. 494 p.

Fenneman, N. M. 1938. Physiography of the eastern United States. First edition. McGraw-Hill, New York, New York, USA. 714 pp.

Fritzell, E. K. 1978. Habitat use by prairie raccoons during the waterfowl breeding period. Journal of Wildlife Management. 42:118-127.

Gehrt, S. D., and E. K. Fritzell. 1997. Sexual differences in home ranges of raccoons. Journal of Wildlife Management. 78:921-931.

Gluek, T. F., W. R. Clark, R. D. Andrews. 1988. Raccoon movement and habitat use during the fur harvest season. Wildlife Society Bulletin. 16:6-11. 
Heske, E. J., S. K. Robinson, and J. D. Brawn. 2001. Nest predation and neotropical migrant songbirds: piecing together the fragments. Wildlife Society Bulletin. 29:52-61.

Hewitt, D. G., D. M. Keppie, and D. F. Stauffer. 2001. Predation effects on forest grouse recruitment. Wildlife Society Bulletin. 29:16-23.

Hoffmann, C. O., and J. L. Gottschang. 1977. Numbers, distribution, and movements of raccoon population in a suburban residential community. Journal of Mammalogy. $58: 623-636$.

Hooge, P. N., and B. Eichenlaub. 1997. Animal movement extension to ArcView. Version 1.1. U. S. Geological Survey, Alaska Biological Science Center, Anchorage, AK.

Hurst, T. E., and M. J. Lacki. 1999. Roost selection, population size, and habitat use by a colony of Rafinesque's big-eared bats (Corynorhinus rafinesquii). American Midland Naturalist. 142:363-371.

Johnson, D. A. 1980. The comparison of usage and availability measurements for evaluating resource preference. Ecology. 61:65-71.

Johnson, S. A. 1970. Biology of the raccoon (Procyon lotor) in Alabama. Agricultural Experiment Station Auburn University Bulletin 402. 148 pp.

Kaufmann, J. H. 1982. Raccoon and Allies. Pages 567-585 in J. A. Chapman and G. A. Feldhamer, editors. Wild mammals of North America. John Hopkins University Press, Baltimore, Maryland. 1147 pp.

Kramer, M. T., R. J. Warren, M. J. Ratnaswamy, and B. T. Bond. 1999. Determining sexual maturity of raccoons by external versus internal aging criteria. Wildlife Society Bulletin. 27:231-234.

Kreeger, T. J. 1996. Handbook of wildlife chemical immobilization. Wildlife Pharmaceuticals, 
Inc., Fort Collins, Colorado. 342 pp.

Lotze, J. H., and S. Anderson. 1979. Procyon lotor. Mammalian Species. 119:1-8.

Rogers, R. 2000. West Virginia raccoon field trial survey 1999-2000. West Virginia Division of Natural Resources, Romney, West Virginia. $11 \mathrm{pp.}$

Rollins, D., and J. P. Carroll. 2001. Impacts of predation on northern bobwhite and scaled quail. Wildlife Society Bulletin. 29:39-51.

Smith, D. W. 1995. The southern Appalachian hardwood region. in Regional Silviculture of the United States. J. W. Barrett editor. John Wiley \& Sons, Inc. New York, New York. $643 \mathrm{pp}$.

Smith, D. M., B. C. Larson, M. J. Kelty and P. M. S. Ashton. 1997. The practice of silviculture: applied forest ecology. John Wiley \& Sons, Inc. New York, New York. $537 \mathrm{pp}$.

Stuewer, F. W. 1943. Raccoons: their habits and management in Michigan. Ecological Monographs. 13:204-257.

Thomas, D. L. and E. J. Taylor. 1990. Study designs and tests for comparing resource use and availability. Journal of Wildlife Management. 54:322-330.

Urban. D. 1970. Raccoon populations, movement patterns, and predation on managed waterfowl marsh. Journal of Wildlife Mana gement. 34:372-382.

White, G. C. and R. A. Garrott. 1990. Analysis of wildlife radio-tracking data. Academic Press Inc., New York. 383 pp. 
Table 1. Rank (5 = most selected; 1 = least selected) for raccoon (Procyon lotor $)$ habitat selection based on the comparison of the percentage of habitat associated with: 1) core homerange (50\% adaptive kernel method) and the $95 \%$ adaptive kernel method homerange estimate; 2) active raccoon locations with the $95 \%$ adaptive kernel method homerange estimate on the MeadWestvaco Wildlife and Ecosystem Research Forest, Randolph County, West Virginia, during August 2000 - March 2003.

\begin{tabular}{lcc}
\hline & \multicolumn{2}{c}{ Rank } \\
\cline { 2 - 3 } Habitat type & Core $v .95 \%$ Homerange & $\begin{array}{c}\text { Active location } v .95 \% \\
\text { Homerange }\end{array}$ \\
\hline Riparian & 5 & 3 \\
Intact & 4 & 5 \\
Regeneration & 0 & 4 \\
Diameter-limit & 2 & 2 \\
Open & 1 & 1 \\
Road & 3 & 0 \\
\hline
\end{tabular}


Table 2. Rank $(5=$ most selected; $1=$ least selected) for raccoon (Procyon lotor) habitat selection during summer and fall based on the comparison of the percentage of habitat associated with active raccoon locations with the $95 \%$ adaptive kernel method homerange estimate on the MeadWestvaco Wildlife and Ecosystem Research Forest, Randolph County, West Virginia, during August 2000 - March 2003.

\begin{tabular}{lcc}
\hline & & Rank \\
\cline { 2 - 3 } Habitat type & Summer & Fall \\
\hline Riparian & 5 & 2 \\
Intact & 3 & 5 \\
Regeneration & 4 & 3 \\
Diameter-limit & 2 & 4 \\
Open & 1 & 1 \\
Road & 0 & 0 \\
\hline
\end{tabular}




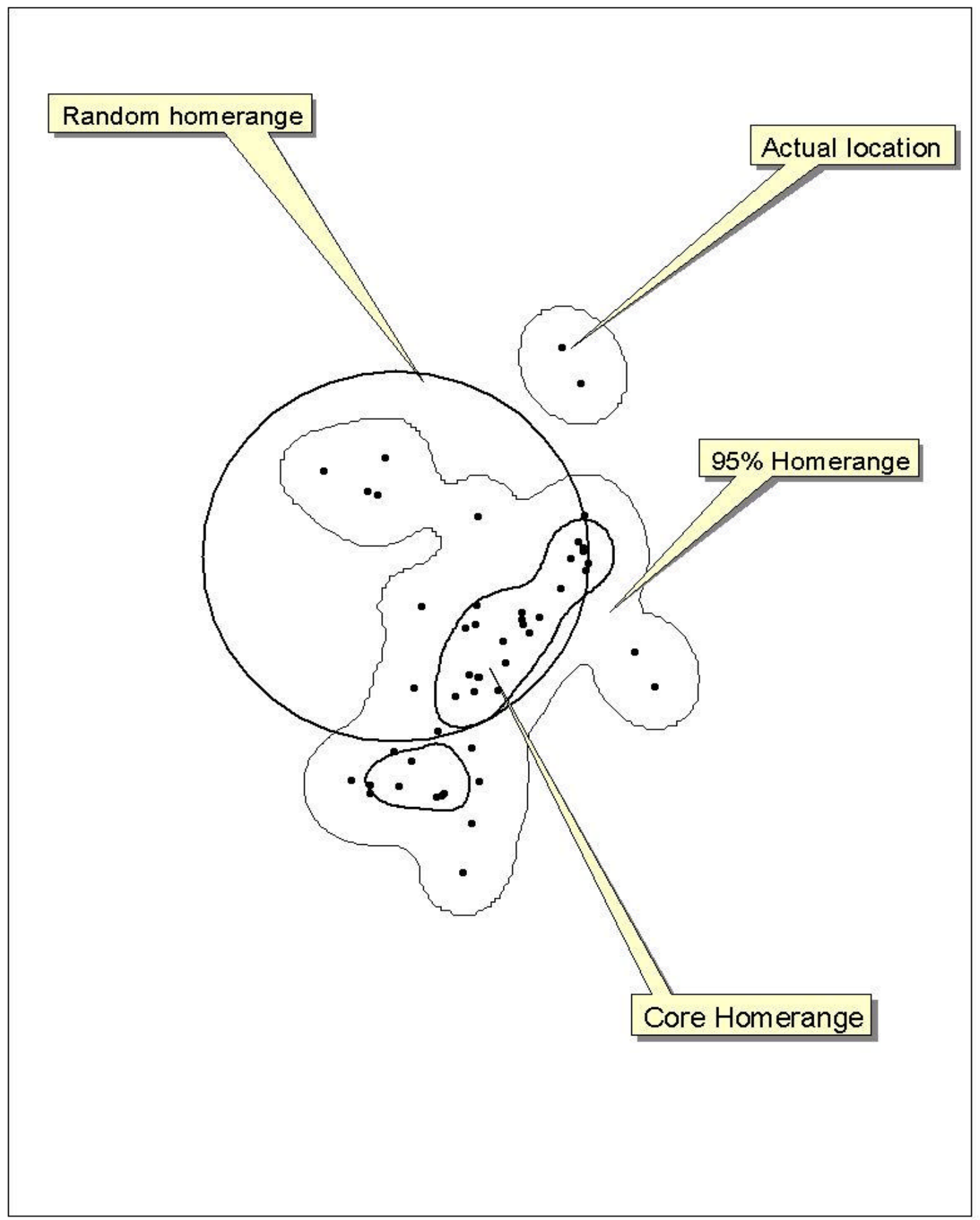

Figure 1. Habitat selection at three spatial scales: (1) composition of each $95 \%$ adaptive kernel method homerange to the composition of random homeranges (equal to the average $95 \%$ homerange size) within a composite homerange derived from all locations combined; (2) corehomerange (50\% adaptive kernel method) composition to composition of the $95 \%$ adaptive kernel method homerange; (3) composition associated with the actual locations to the composition of the $95 \%$ adaptive kernel method homerange. 


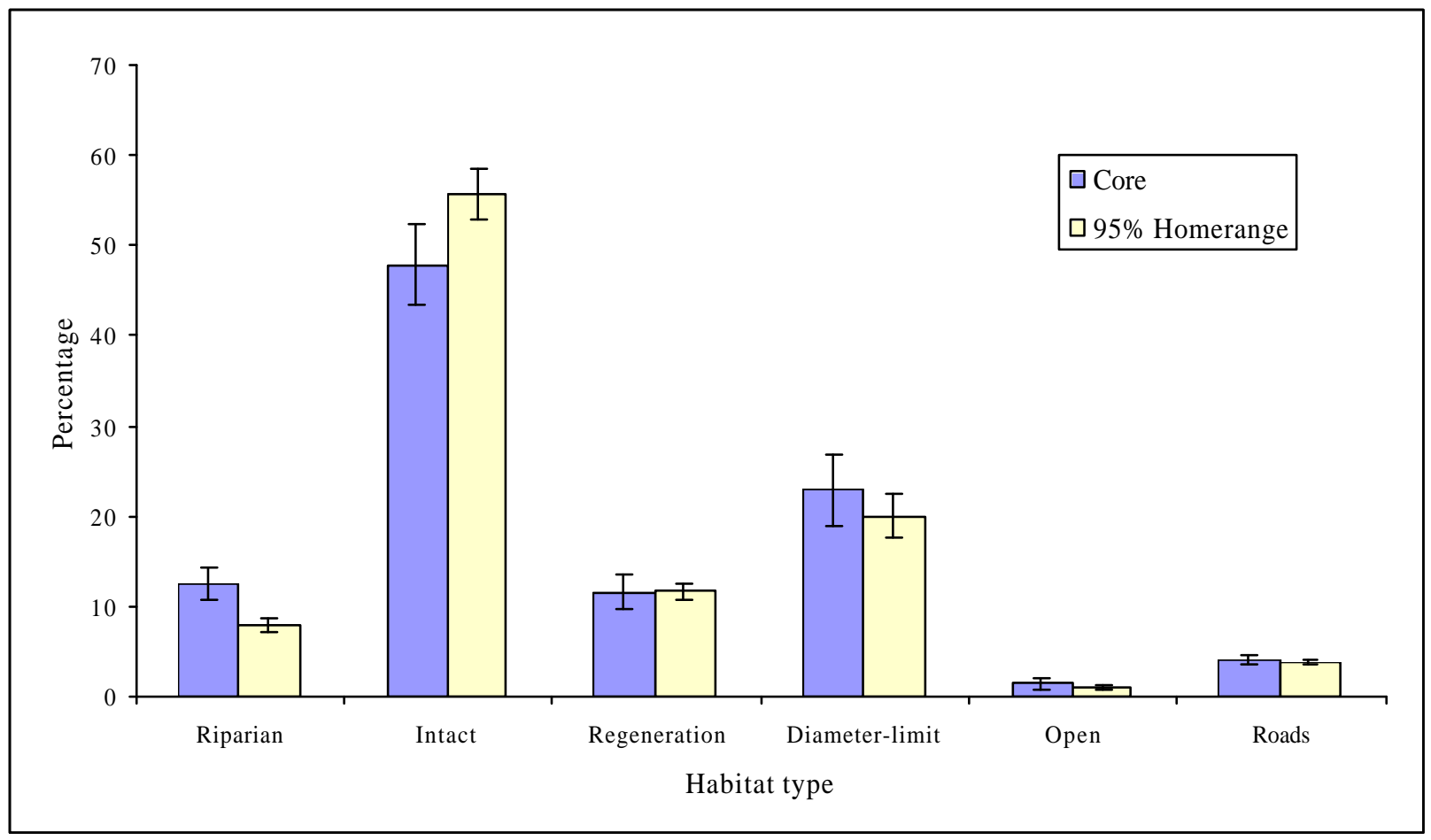

Figure 2. Percent use $( \pm \mathrm{SE})$ in the core-homerange (50\% adaptive kernel method homerange estimate) and percent used $( \pm \mathrm{SE})$ in $95 \%$ adaptive kernel method home range in each habitat type for raccoon (Procyon lotor) on the MeadWestvaco Wildlife and Ecosystem Research Forest, Randolph County, West Virginia, during August 2000 - March 2003. 


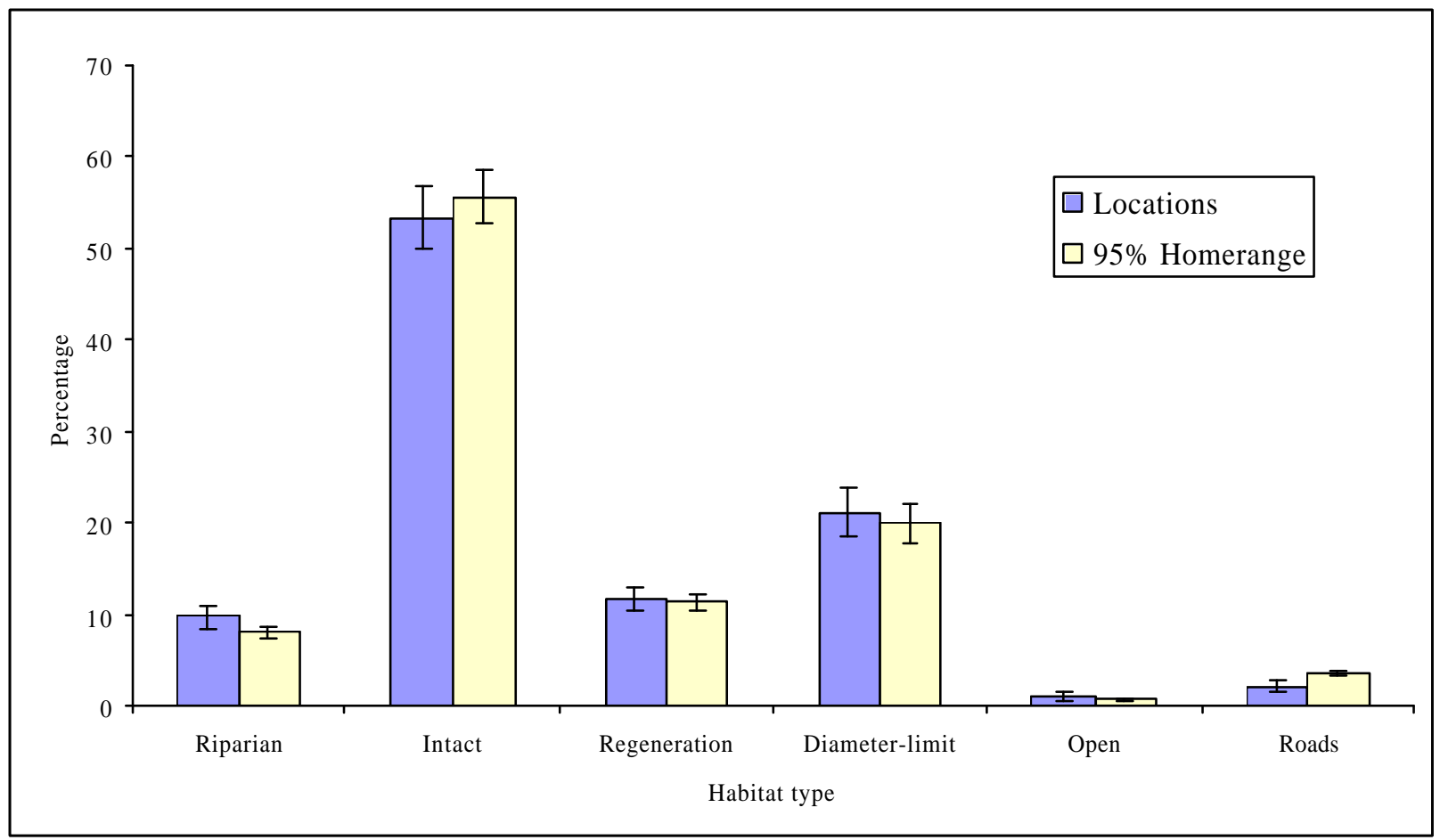

Figure 3. Percent used $( \pm \mathrm{SE})$ associated with the actual locations and percent available $( \pm \mathrm{SE})$ in 95\% adaptive kernel method home range in each habitat type for raccoon (Procyon lotor) on the MeadWestvaco Wildlife and Ecosystem Research Forest, Randolph County, West Virginia, during August 2000 - March 2003. 


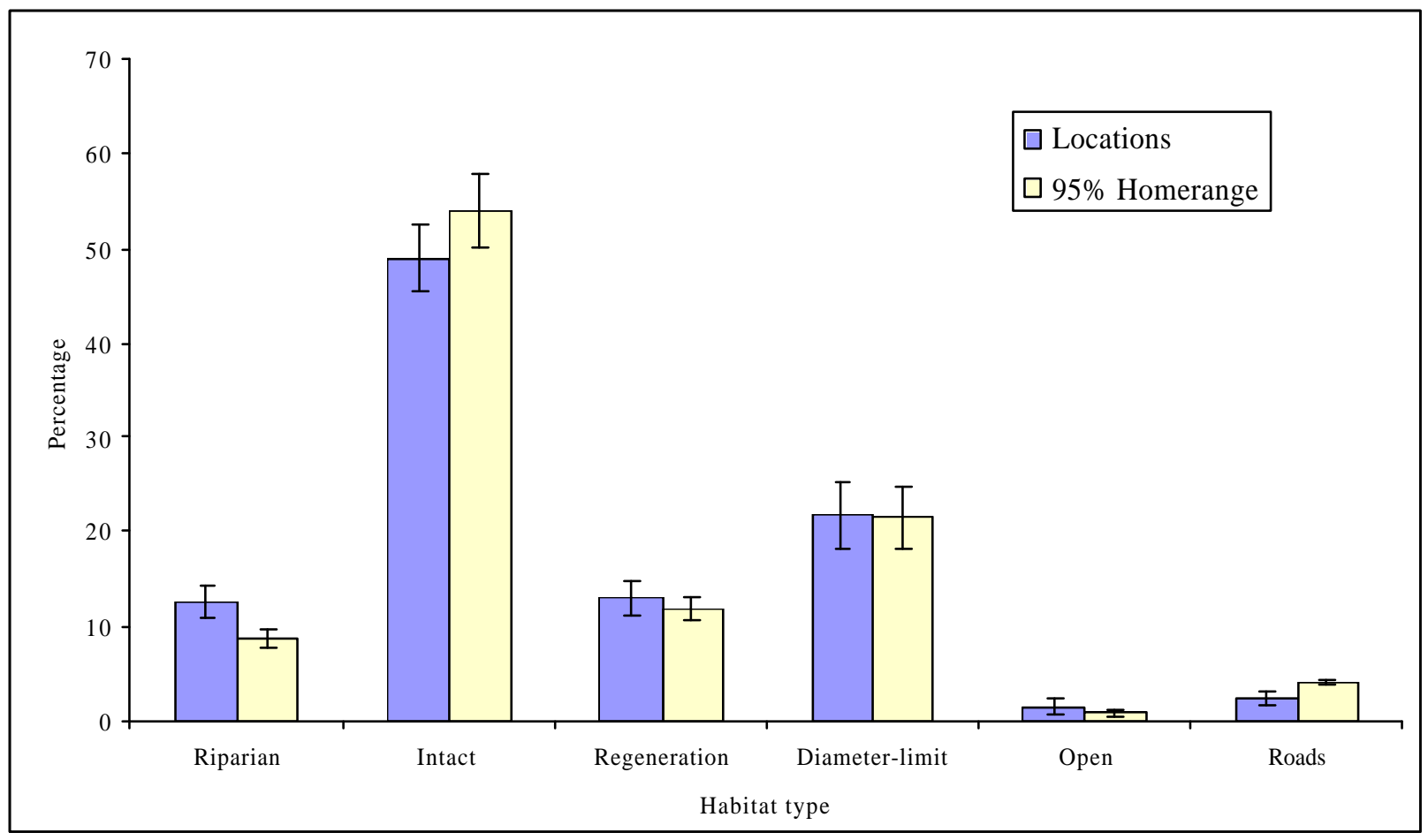

Figure 4. Summer estimates for percent used $( \pm \mathrm{SE})$ associated with the actual locations and percent available $( \pm \mathrm{SE})$ in $95 \%$ adaptive kernel method home range in each habitat type for raccoon (Procyon lotor) on the MeadWestvaco Wildlife and Ecosystem Research Forest, Randolph County, West Virginia, during August 2000 - March 2003. 


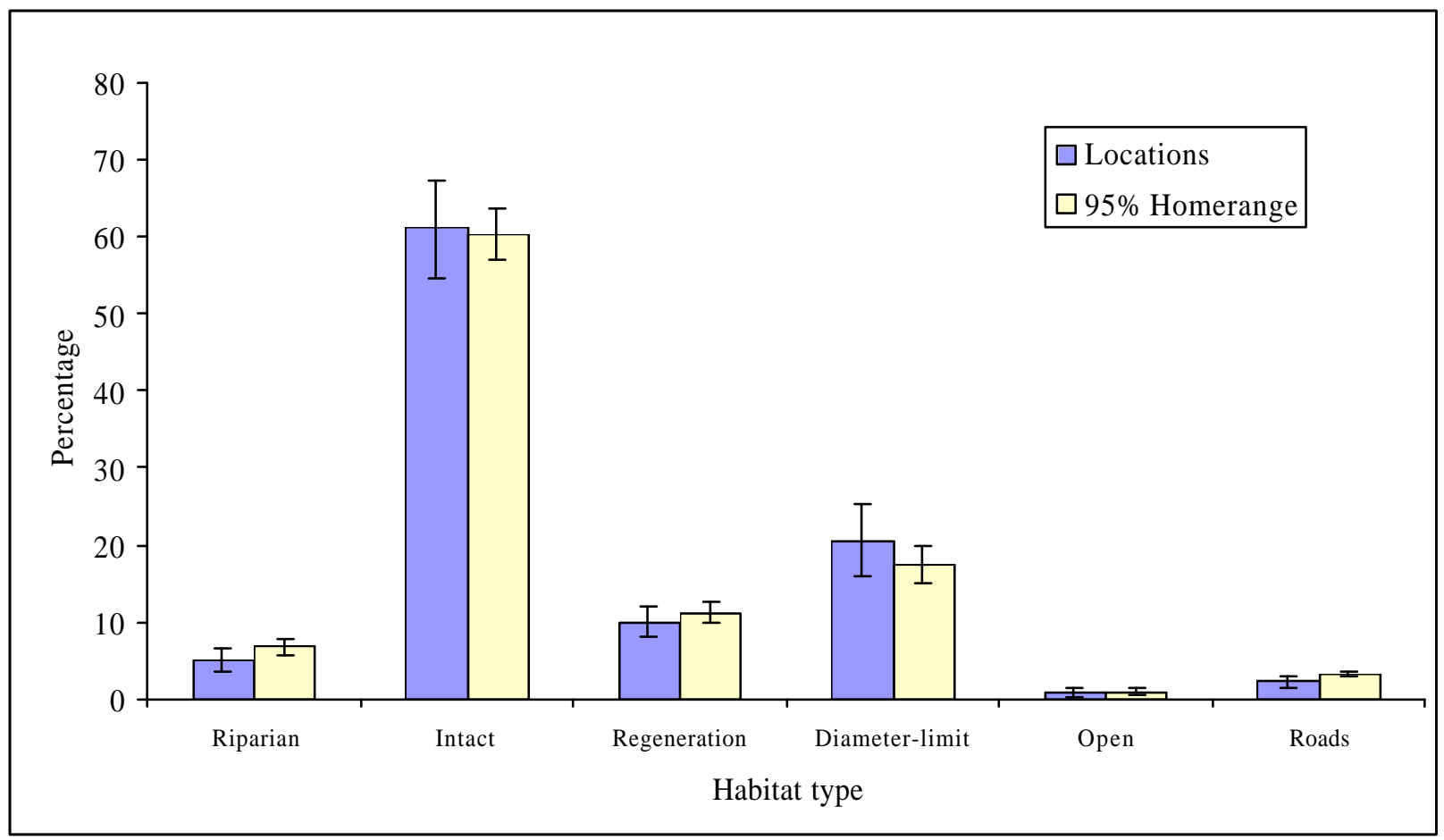

Figure 5. Fall estimates for percent used $( \pm \mathrm{SE})$ associated with the actual locations and percent available $( \pm \mathrm{SE})$ in $95 \%$ adaptive kernel method home range in each habitat type for raccoon (Procyon lotor) on the MeadWestvaco Wildlife and Ecosystem Research Forest, Randolph County, West Virginia, during August 2000 - March 2003. 


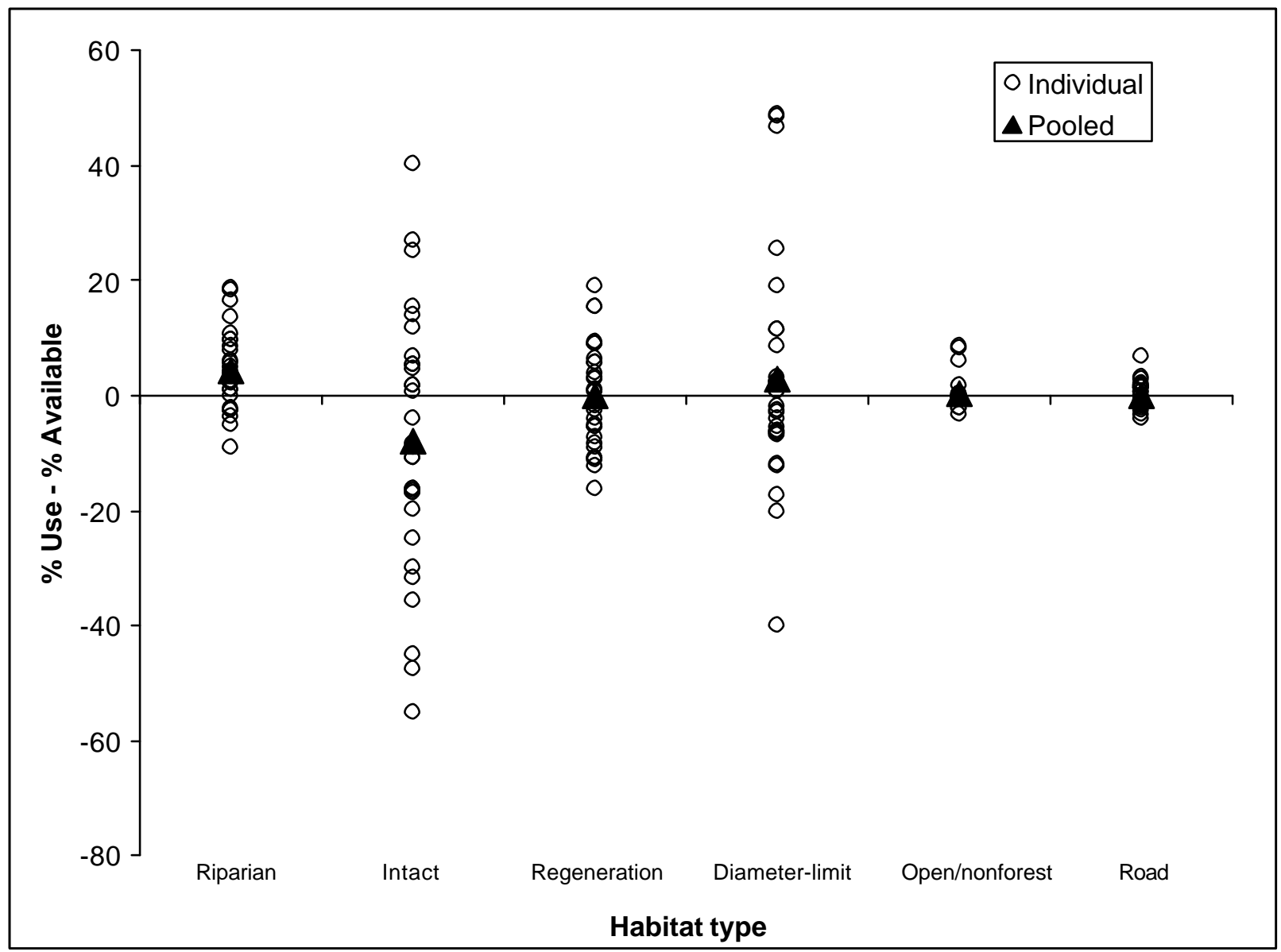

Figure 6. Individual variation in the difference of percent use and percent available for the corehomerange and 95\% adaptive kernel method for raccoon (Procyon lotor) on the MeadWestvaco Wildlife and Ecosystem Research Forest, Randolph County, West Virginia, during August 2000 - March 2003. 


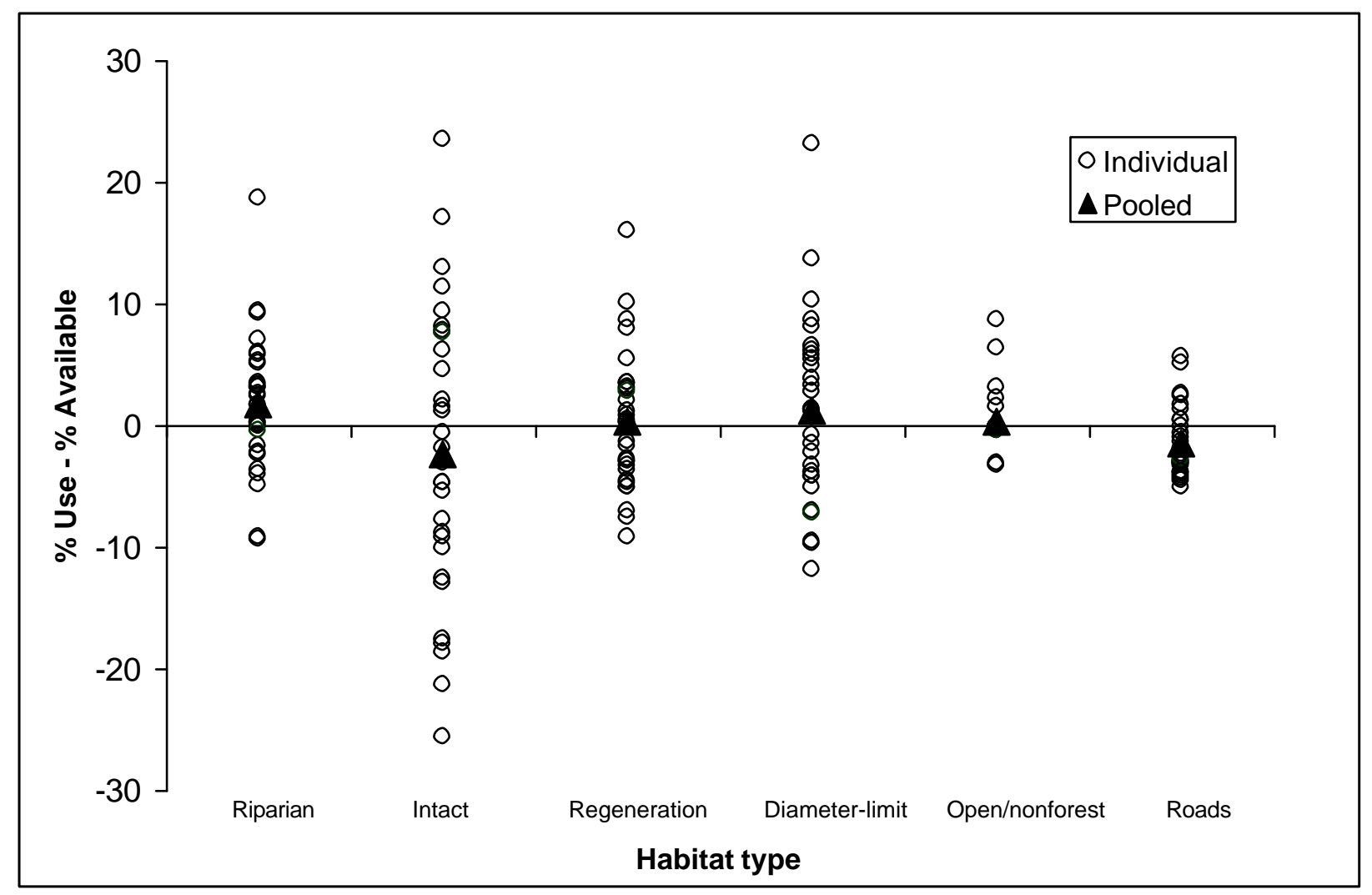

Figure 7. Individual variation in the difference of percent use and percent available for the habitat associated with the actual locations and 95\% adaptive kernel method for raccoon (Procyon lotor) on the MeadWestvaco Wildlife and Ecosystem Research Forest, Randolph County, West Virginia, during August 2000 - March 2003. 


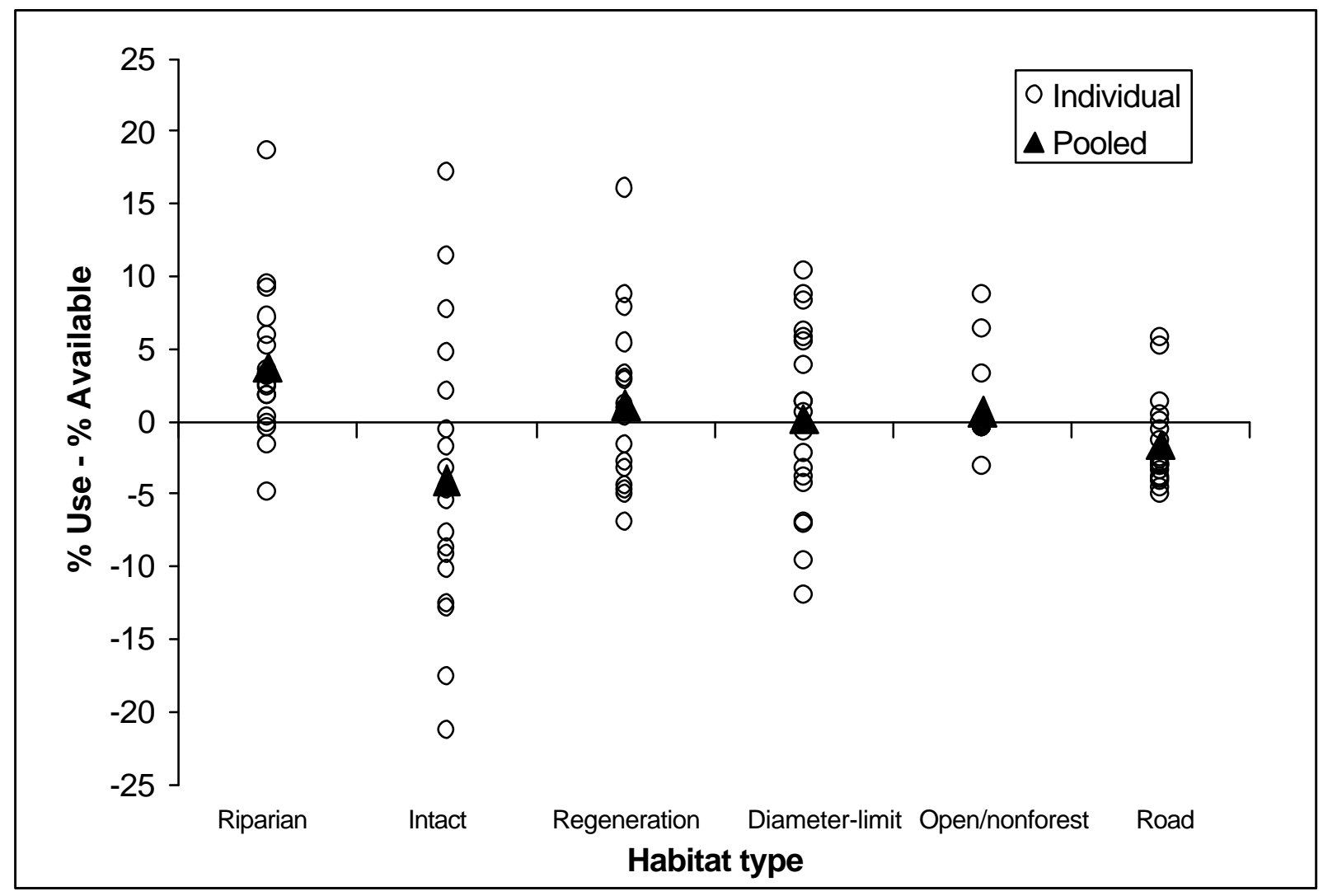

Figure 8. Summer individual variation in the difference of percent use and percent available for the habitat associated with the actual locations and 95\% adaptive kernel method for raccoon (Procyon lotor) on the MeadWestvaco Wildlife and Ecosystem Research Forest, Randolph County, West Virginia, during August 2000 - 2003. 


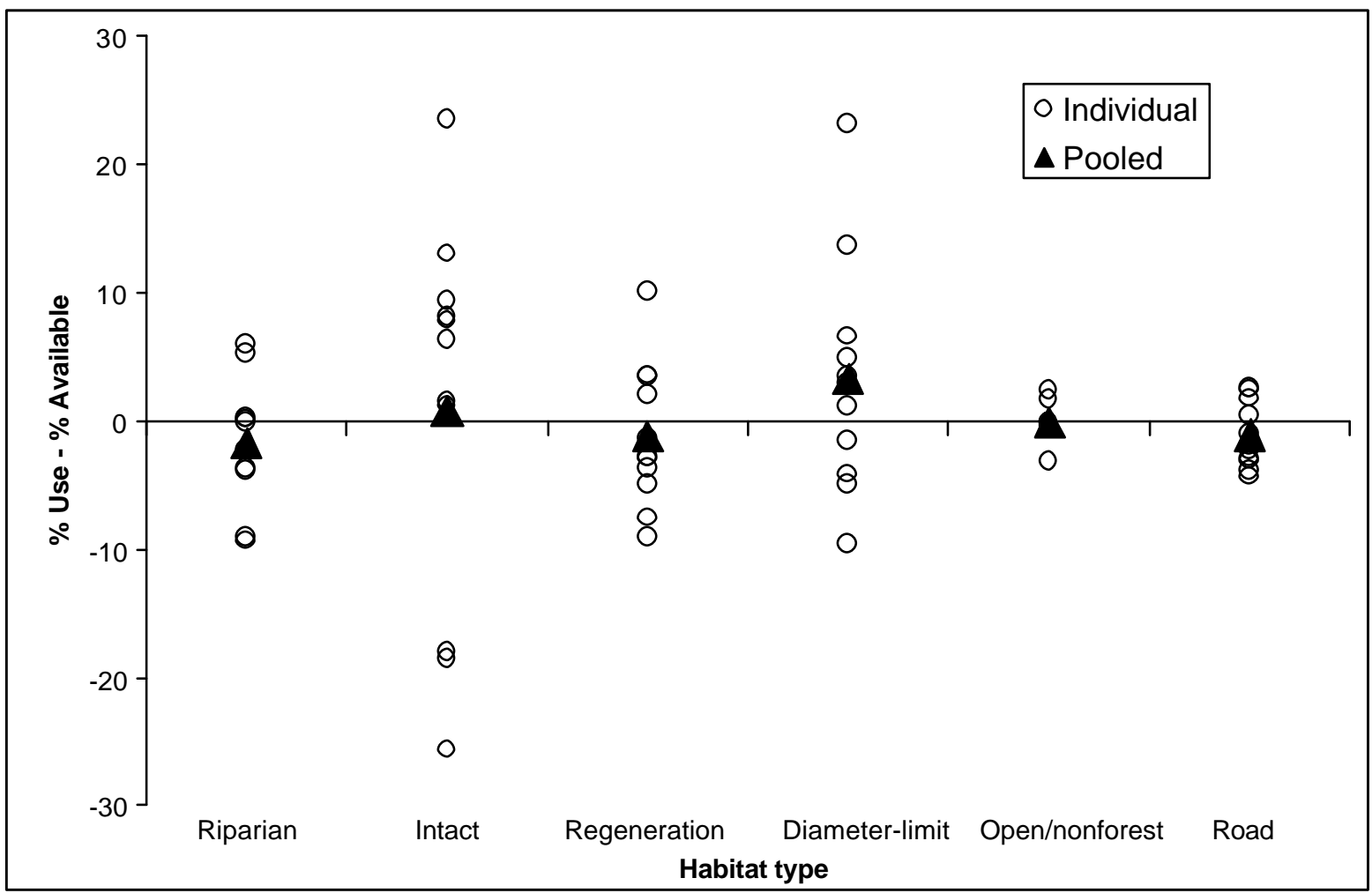

Figure 9. Fall individual variation in the difference of percent use and percent available for the habitat associated with the actual locations and 95\% adaptive kernel method for raccoon (Procyon lotor) on the MeadWestvaco Wildlife and Ecosystem Research Forest, Randolph County, West Virginia, during August 2000 - March 2003. 
Appendix A. Summary of raccoon telemetry data on the MeadWestvaco Wildlife and Ecosystem Research Forest, Randolph County, West Virginia, during August 2000 - March 2003.

\begin{tabular}{|c|c|c|c|c|c|c|c|}
\hline \multirow[b]{2}{*}{ Raccoon ID } & \multirow[b]{2}{*}{ Season } & \multirow[b]{2}{*}{ Year } & \multirow[b]{2}{*}{ Tracking period } & \multirow[b]{2}{*}{ Sex } & \multirow[b]{2}{*}{ \#Locations } & \multicolumn{2}{|c|}{ Homerange } \\
\hline & & & & & & Core & $95 \%$ AKM \\
\hline 638 & summer & 2001 & May - August & female & 30 & 40.9 & 429.1 \\
\hline 098 & summer & 2001 & April - August & male & 48 & 183.4 & 701.5 \\
\hline 484 & summer & 2001 & June - August & female & 50 & 40.1 & 207.7 \\
\hline 184 & summer & 2001 & May - August & male & 44 & 29.1 & 361.3 \\
\hline 220 & summer & 2001 & May - August & male & 46 & 29.7 & 343.0 \\
\hline 381 & summer & 2001 & May - August & male & 36 & 96.2 & 642.8 \\
\hline 718 & summer & 2001 & May - August & female & 49 & 63.3 & 343.2 \\
\hline 718 & fall & 2001 & September-December & female & 43 & 21.3 & 227.7 \\
\hline 184 & fall & 2001 & September-December & male & 52 & 24.2 & 311.3 \\
\hline 638 & fall & 2001 & September-December & female & 36 & 6.5 & 581.8 \\
\hline 484 & fall & 2001 & September - December & female & 51 & 48.9 & 249.2 \\
\hline 381 & fall & 2001 & September - December & male & 30 & 55.2 & 381.3 \\
\hline
\end{tabular}


Appendix A. cont.

\begin{tabular}{|c|c|c|c|c|c|c|c|}
\hline \multirow[b]{2}{*}{ Raccoon ID } & \multirow[b]{2}{*}{ Season } & \multirow[b]{2}{*}{ Year } & \multirow[b]{2}{*}{ Tracking period } & \multirow[b]{2}{*}{ Sex } & \multirow[b]{2}{*}{ \#Locations } & \multicolumn{2}{|c|}{ Homerange } \\
\hline & & & & & & Core & $95 \%$ AKM \\
\hline 034 & summer & 2002 & May - August & male & 61 & 169.7 & 630.0 \\
\hline 214 & summer & 2002 & May - August & female & 59 & 15.6 & 148.4 \\
\hline 432 & summer & 2002 & May - August & male & 46 & 30.8 & 491.4 \\
\hline 424 & summer & 2002 & April - August & male & 46 & 34.1 & 330.5 \\
\hline 203 & summer & 2002 & April - August & female & 46 & 13.4 & 204.9 \\
\hline 133 & summer & 2002 & April - August & female & 49 & 10.1 & 120.0 \\
\hline 685 & summer & 2002 & May - August & male & 31 & 51.4 & 254.9 \\
\hline 572 & summer & 2002 & May - July & male & 30 & 32.2 & 140.6 \\
\hline 193 & summer & 2002 & May- August & male & 54 & 16.5 & 141.2 \\
\hline 114 & summer & 2002 & May - August & female & 49 & 31.1 & 269.9 \\
\hline 163 & summer & 2002 & May - August & male & 36 & 34.7 & 206.7 \\
\hline 545 & summer & 2002 & May - July & female & 46 & 27.1 & 145.1 \\
\hline 613 & fall & 2002 & September - November & male & 32 & 28.2 & 394.4 \\
\hline
\end{tabular}


Appendix A. cont.

\begin{tabular}{llllllll}
\hline & & & & & \multicolumn{2}{c}{ Homerange } \\
\cline { 5 - 7 } Raccoon ID & Season & Year & Tracking period & Sex & \#Locations & Core & $95 \%$ AKM \\
\hline 214 & fall & 2002 & September - November & female & 35 & 7.7 & 105.0 \\
034 & fall & 2002 & September - November & male & 34 & 41.9 & 416.6 \\
133 & fall & 2002 & September - November & female & 35 & 19.5 & 144.1 \\
424 & fall & 2002 & September - November & male & 31 & 84.4 & 380.9 \\
432 & fall & 2002 & September - November & male & 39 & 177.6 & 570.4
\end{tabular}




\title{
Chapter 2
}

\section{Den-site selection of raccoons (Procyon lotor) within an intensively managed forest in central West Virginia.}

Sheldon F. Owen, Wildlife and Fisheries Resources Program, Division of Forestry, Box 6125, West Virginia University, Morgantown, WV 26506-6125, USA

John W. Edwards, Wildlife and Fisheries Resources Program, Division of Forestry, Box 6125, West Virginia University, Morgantown, WV 26506-6125, USA

W. Mark Ford, USDA Forest Service, Northeastern Forest Experiment Station, Fernow Experimental Forest, Box 404, Parsons, WV 26287, USA

Petra Bohall Wood, West Virginia Cooperative Fish and Wildlife Research Unit, USGS-BRD, Box 6125, Morgantown, WV 26505-6125, USA

\begin{abstract}
As part of a raccoon ecology study in intensively managed forests in the Allegheny Mountains of central West Virginia, we tracked 32 raccoons to 175 diurnal den sites that included cavity trees, rock dens, $\log$ piles, slash piles, and various exposed limbs. Overall, den selection differed between genders, seasons and among den types used. Female raccoons selected tree cavities as maternal den sites. Overall, 62 cavity dens were recorded in 12 tree species; seven maternal dens were found in five tree species. Although we found no difference in cavity tree diameter between genders, cavity trees had larger diameters during winter than in spring and summer for both genders. We also found no difference in cavity height between genders or among seasons. Because raccoons are very adaptable and capable of using a variety of den structures, den abundance may not be the primary limiting factor to raccoon populations
\end{abstract}


within intensively managed forests. However, because female raccoons selected cavities as maternal sites, the continued loss of large diameter trees without replacement in 40-60 year rotations may impact future raccoon recruitment.

\section{INTRODUCTION}

Cavity tree abundance was once thought to be a limiting factor to raccoon abundance across their range in the Southeast, but research has found raccoons to use a variety of den sites (Johnson 1970, Endres and Smith 1993) including tree cavities, underground burrows, rock outcrops, and human-made shelters (Rabinowitz and Pelton 1986, Endres and Smith 1993, Robb et al. 1996). Dorney (1954) reported raccoons in marsh areas using ground vegetation, ground burrows, and muskrat houses even though trees were available. Researchers have reported significant use of tree dens during spring and summer by raccoons in the southern Appalachians of Tennessee (Rabinowitz and Pelton 1986, Endres and Smith 1993). Investigations of the denning habits of raccoons have primarily occurred in regions of the country (Johnson 1970, Rabinowitz and Pelton 1986, Endres and Smith 1993) other than in the heavily forested central Appalachian Mountains.

In the central Appalachian Mountains, large diameter trees with den cavities may be of limited quantity and quality because of past timber harvests and present forest management (Rosenberg et al. 1988). Female raccoons have been found to select cavities as maternal den sites, and therefore a lack of suitable sites may affect recruitment. Moreover, an absence of tree cavities may force raccoons to use alternative den sites, which may displace other den-seeking animals such as the Allegheny woodrat (Neotoma magister), disrupt predator-prey associations, and alter disease contact parameters. 
Possible increased interactions also are important because the Allegheny woodrat can be adversely affected by larvae of the raccoon roundworm. Allegheny woodrat declines in the Northeast are due in part to fatal infection of raccoon roundworm (Balcom and Yahner 1996).

Limited information is available on how changes in forest structure and species composition impact tree cavity suitability and use. Consequently, our objective was to determine seasonal and gender-specific den site selection of raccoons in an intensively managed forest.

\section{STUDY AREA}

Our study was centered on the 3630 ha MeadWestvaco Wildlife and Ecosystem Research Forest (MWERF) located in the Allegheny Mountain and Plateau physiographic sub-province in Randolph County, West Virginia. The MWERF is an intensively managed forest dedicated to the study of the interaction of industrial forestry with Appalachian ecosystems. Elevations range from $700 \mathrm{~m}$ to $1200 \mathrm{~m}$ with steep side-slope mountains, broad ridge tops, and narrow valleys. The underlying geologic material is primarily Pottsville series shale and sandstone, along with limestone (Fenneman 1938). Emergent rock outcrops formed along mountain ridgelines as shale eroded and the more resistant sandstone remained. The climate is cool and moist, with a growing season of approximately 150 days (Smith 1995). The MWERF is a second- and third-growth Allegheny-northern hardwood forest dominated by black cherry (Prunus serotina), sugar maple (Acer saccharum), red maple (A. rubrum), yellow birch (Betula alleghaniensis), American beech (Fagus grandifolia), and northern red oak (Quercus rubra) except for higher elevations that are characterized by red spruce (Picea rubens) and Eastern 
hemlock (Tsuga canadensis) communities. Riparian areas are characterized by the aforementioned tree species and rosebay rhododendron (Rhododendron maximum).

Five vegetation types are located on the forest: (1) intact mid-aged to mature forest, (2) diameter-limit harvests, (3) deferment harvests, (4) clearcuts, and (5) open/roads or nonforest areas. Intact forests are second-growth stands with no mechanical disturbance since stand initiation whereas diameter-limit stands had approximately $50 \%$ of the basal area removed during repeated harvests over the past two decades. Deferment and clearcut harvests are similar in silvicultural function, however, approximately $10 \%$ of the initial basal area was left on site in deferment cuts whereas all trees $>2.5 \mathrm{~cm}$ diameter at breast height (dbh) were removed in the clearcuts. Most deferment and clearcut stands were 0-10 years of age. As part of the long-term Appalachian Landscape Ecology project, harvest intensities are increasing to disturbance levels that mimic 20- and 40-year rotations in addition to the standard 80-year rotation on nine 530 ha compartments on the MWERF and surrounding tracts.

\section{METHODS}

We used $38 \times 38 \times 107 \mathrm{~cm}$ and $25 \times 25 \times 81 \mathrm{~cm}$ cage traps $\left(\right.$ Havahart ${ }^{\circledR}$, Woodstream Corporation, Lititz, PA) baited with sardines, other forms of rancid meats, and marshmallows to live-catch raccoons. We chemically immobilized raccoons with 30 $\mathrm{mg} / \mathrm{kg}$ Ketamine plus $4 \mathrm{mg} / \mathrm{kg}$ Xylazine (Kreeger 1999). Yohimbine $(0.15 \mathrm{mg} / \mathrm{kg})$ was used as an antagonist to Xylazine. Immobilized raccoons were aged as juvenile or adult (Johnson 1970, Kramer et al. 1999) and gender was determined according to external characteristics. Each individual was ear-tagged with a uniquely numbered Jiffy size 3

aluminum tag (National Band and Tag Co., Newport, KY) and weighed. Measurements 
were taken for total length, ear length, and hind-foot length. Adult males and females were equipped with mortality sensitive radio collars (Advanced Telemetry Systems, Asanti, MN; AVM Instrument Company, Ltd., Colfax, CA). Radio collars weighed approximately 70 grams and had a battery life of 18 months. We only tagged adults to avoid the chance of dispersing sub-adults leaving the study area.

We used Wildlife Materials TRX-2000S receivers (Wildlife Materials Inc., Carbondale, IL, and 3-element Yagi antennas to locate den sites of transmittered raccoons. Using homing techniques during diurnal periods of inactivity, we approached dens on foot and confirmed actual locations visually. We located den sites of transmittered animals approximately 2 to 3 times weekly. We considered each location as independent and calculated relative frequency of use for each den type among seasons, and between gender and year. We defined seasons as spring (March-May), summer (June-September), and winter (October-February).

We conducted cavity tree surveys to determine availability and distribution across the MWERF. We searched the study area for available tree cavities by randomly establishing $4,0.25$ ha plots in each of 2 replicates within 4 vegetation types (upland and riparian intact forest and diameter-limit stands) across the study area (Robb et al. 1996). Cavity trees were considered available if diameter at breast height (dbh) was $>30 \mathrm{~cm}$ (based on our findings of minimal size cavity used). We did not include deferment harvest or clearcuts in cavity tree searches because we found no raccoons using cavities within deferment harvests and cavity trees were absent within clearcuts.

We used loglinear regression (PROC CATMOD; SAS 1999) to determine differences in percentage used among years, seasons, types, and between genders. We 
then used multiple contingency table analyses to compare differences within season, type, and gender based on significant findings from loglinear regression. We compared cavity characteristics using a three-way ANOVA testing for differences in dbh and height among seasons and between years and gender. We set significance levels for all statistical tests at $\mathrm{a}=0.05$.

\section{RESULTS}

We radio-collared and monitored den site selection of 32 adult raccoons (19 male; 13 female) from October 2000 through March 2003. From those 32 individuals, we located 175 individual diurnal resting sites including tree cavities $(n=58)$, rock dens $(n=$ 47), exposed limbs $(n=34), \log$ piles $(n=19)$, slash piles $(n=12)$, and other structures $(n=5)$. For statistical comparisons we classified diurnal-den sites into 5 categories: tree cavities, log piles, rock dens, exposed limbs, and other (slash piles, stump holes, downedhollow logs, and a shed). Relative frequency of den use (including initial location and revisits) was distributed among den types as follows: cavity $=104(38 \%)$; rock dens 70 (25\%); log piles 45 (16\%); exposed limbs 40 (15\%); and other structures $16(6 \%)$.

Using relative frequency of use, the overall loglinear model was significant for year, gender, season, and type $\left(?^{2}=60.62, d f=28, P=0.0003\right)$. We found significant differences among years $\left(?^{2}=30.06, d f=2, P<0.0001\right)$, however, there were no significant interactions between year and any other variable. Therefore, we blocked by year and tested for den use differences among seasons, gender, and type. Relative frequency of use was not different between genders $\left(?^{2}=0.01, d f=1, P=0.9201\right)$ or among seasons $\left(?^{2}=5.77, d f=2, P=0.0559\right)$; however, it was different among den type $\left(?^{2}=16.22, d f=4, P=0.0027\right)$. We did not find a significant interaction between gender 
and season $\left(?^{2}=1.38, d f=2, P=0.5010\right)$. However, we found significant interactions among gender and type $\left(?^{2}=19.17, d f=4, P=0.0007\right)$, season and type $\left(?^{2}=26.62, d f=\right.$ $8, P=0.0008)$, and a three-way interaction among gender, season and type $\left(?^{2}=15.61, d f\right.$ $=8, P=0.0483)$.

Male and female raccoons used tree cavities more often in summer $(59 \%)\left(?^{2}=\right.$ 7.89, $d f=2, P=0.0194)$ than in spring $(27 \%)$ or in winter $(14 \%)$. Log piles were used equally across seasons (spring 27\%; summer $35 \%$; winter $38 \%$ ) but were used less than expected based on other den types used $\left(?^{2}=7.77, d f=2, P=0.0205\right)$. Rock dens were used more often $\left(?^{2}=23.99, d f=2, P<0.0001\right)$ in winter $(44 \%)$ than in spring $(23 \%)$ or summer $(33 \%)$.

Among seasons, females (67\%) used tree cavities more often than males $(33 \%)$ $\left(?^{2}=23.11, d f=1, P<0.0001\right)$. Males used log piles $(64 \%)$ slightly more than females $(36 \%)\left(?^{2}=3.74, d f=1, P=0.0532\right)$, and males used rock dens $(66 \%)$ more often than females $(34 \%)\left(?^{2}=7.84, d f=1, P=0.0051\right)$.

In spring and summer, tree cavity use by females (57\% and 64\%, respectively) was higher than any other cavity type. Tree cavity use by females was also higher $\left(?^{2}=\right.$ $13.49, d f=2, P=0.0012)$ in summer $(62 \%)$ than in both spring $(24 \%)$ and winter $(14 \%)$. Log pile use by females was higher $\left(?^{2}=26.68, d f=2, P<0.0001\right)$ in winter $(81 \%)$ than in both summer $(6 \%)$ and spring $(13 \%)$. Rock den use by females was higher $\left(?^{2}=7.88\right.$, $d f=2, P=0.0195)$ in winter $(50 \%)$ than in both spring $(21 \%)$ and summer $(29 \%)$.

Tree cavity use by males was evenly distributed $\left(?^{2}=1.66, d f=2, P=0.4343\right)$ among seasons and also equally distributed among other den types used. However, the relative frequency of rock dens used by males was higher $\left(?^{2}=21.04, d f=2, P<0.0001\right)$ 
in winter $(41 \%)$ than in spring (24\%) and summer (35\%). Relative frequency of log piles used by males was evenly distributed among seasons $\left(?^{2}=2.13, d f=2, P=0.3440\right)$.

We found tree cavities in 12 different species including: yellow-poplar (Liriodendron tulipifera) $(n=19)$, eastern hemlock $(n=6)$, Fraser magnolia (Magnolia fraseri) $(n=6)$, American beech $(n=5)$, sugar maple $(n=4)$, basswood (Tilia americana) $(n=4)$, black cherry $(n=4)$, chestnut oak $(Q$. prinus $)(n=4)$, northern red oak $(n=2)$, white ash (Fraxinus americana) $(n=1)$, cucumber magnolia (Magnolia acuminata $)(n=1)$, sourwood $($ Oxydendrum arboreum $)(n=1)$, and unknown spp. $(n=$ 5). We found no difference in mean cavity tree diameter between genders $(F=1.03, d f=$ $1, P=0.3160)$. However, we did find that diameters of cavity trees were larger in 2001 than $2002(F=8.75, d f=1, P<0.0047)$, and significantly larger in winter than spring or summer $(F=15.88, d f=3, P<0.0001)$ (Fig. 2). We also found no difference in mean cavity height between genders $(F=0.96, d f=1, P=0.7241)$, nor among seasons $(\mathrm{F}=$ 1.49, $d f=3, P=0.2347$ ) (Fig. 3). Although not significant at 0.05 , we found cavity heights to be slightly greater in 2002 than $2001(F=3.93, d f=1, P=0.0530)$.

We found that 7 of 8 maternal dens occurred in cavity trees with a mean diameter of $58 \mathrm{~cm}(\mathrm{SE}=5.8$; range 39.4 - 71.1). Maternal cavities were found in 5 species including yellow-poplar $(n=3)$, basswood $(n=1)$, Fraser magnolia $(n=1)$, American beech $(n=1)$, and black cherry $(n=1)$. We also found one maternal den in an abandoned shed.

Based on cavity availability surveys, we estimated cavity tree density to be 1.3 cavity trees per hectare. Average cavity tree dbh was $50 \mathrm{~cm}$ (range 39 - 57). Available 
cavity trees included sugar maple $(n=3)$, red maple $(n=2)$, yellow-poplar $(n=1)$, Fraser magnolia $(n=1)$, red oak $(n=1)$, black cherry $(n=1)$, and American beech $(n=1)$.

\section{DISCUSSION}

The relative importance of dens within the hierarchy of resources required by raccoons is uncertain, but it varies among seasons and among raccoon age and sex classes within seasons (Rabinowitz and Pelton 1986, Endres and Smith 1993). Because of their generalist habits and opportunistic behavior, raccoons use a variety of den sites including unused squirrel nests, tree roosts, barns, underground burrows, rock outcrops, tree cavities (Rabinowitz and Pelton 1986, Endres and Smith 1993, Robb et al. 1996), and Wood Duck (Aix sponsa) nest boxes (J. Henneker, pers communication). Raccoons on the MWERF also used a variety of structures including tree cavities, log piles, rock dens, exposed limbs, slash piles, downed hollow logs, and even an abandoned shed. Similar to other studies, our results indicate the greatest variation in den types used occurred during the warmer seasons of spring and summer. The three most commonly used structures on the MWERF were tree cavities, rock dens, and log piles.

Johnson (1970) found that seasonal variation in raccoon den selection was influenced by resource patchiness or proximity to food or water resources. Whereas, Berner and Gysel (1976) and Endres and Smith (1993) found raccoons using dens in proportion to their availability. These studies were conducted in areas containing clearly defined agricultural crops, marshes, or wetland areas in Alabama (Johnson 1970) and the central basin of Tennessee (Endres and Smith 1996). In contrast, our study area was an intensively managed forest within the heavily (85\%) forested central Appalachians where such habitat types virtually are absent. Because clearly defined foraging resources are 
less evident in mostly forested habitat, den selection may appear more random and not based on juxtaposition to foraging areas. However, during late summer we found increased use of slash piles in newly regenerating clearcuts coinciding with the ripening of blackberry (Rubus spp.). Such increased use may indicate the opportunistic use of den sites in close proximity to seasonally available food resources.

Raccoons on the MWERF showed a high level of den site fidelity, reusing den sites within and across seasons. Whereas, other researchers have found little fidelity of den sites with respect to continued use among seasons (Endres and Smith 1993). Female raccoons selected tree cavities during parturition, but they did not reuse the previous year's maternal cavity tree. We also found male and female raccoons returning to rock dens and $\log$ piles in winter that were used in the previous year. This may indicate winter site fidelity or a limited number of quality winter dens. Because raccoons remain inactive throughout much of the winter, individual raccoons rarely switched dens during this season.

Tree cavities are commonly reported as preferred den sites of raccoons (Johnson 1970, Lotze and Anderson 1979, Kaufmann 1982). Johnson (1970) found that tree cavities were the most often selected den sites in Alabama, whereas, Endres and Smith (1993) found raccoons using other den types more than tree cavities even though cavity trees were the most abundant den type in central Tennessee. Dorney (1954) reported raccoons in marsh areas using ground vegetation, ground burrows, and muskrat houses even though tree cavities were available. We found raccoons using tree cavities most often in spring and summer and the importance of tree cavities can somewhat be attributed to female selection of cavities as maternal den sites during these periods. We 
found female raccoons selecting tree cavities during the maternal period of mid-May to late-June, often remaining in the same tree for the entire maternal period. We also found female raccoons without litters using tree cavities during late spring and early summer. Other researchers have also indicated that female raccoons select tree cavities during the maternal period (Berner and Gysel 1967, Stuewer et al. 1971, Rabinowitz and Pelton 1986, Endres and Smith 1993). Although advantages of tree cavities as maternal dens are uncertain and often explained as inherent behavioral aspects of pregnancy and parturition (Endres and Smith 1993), tree cavities can provide reduced conflict from interspecific competition, suitable microenvironment, and protection from predators (Berner and Gysel 1967, Endres and Smith 1993).

Our findings of female raccoons selecting tree cavities as maternal den sites suggests a potential limiting factor in recruitment. In the central Appalachians, extensive timber harvesting in the early 1900's and again since the early 1980's has produced a complex landscape of stands $\leq 80$ years old (McGarigal and Fraser, 1984; Rosenberg et al., 1988; DiGiovanni, 1990) with virtually no remaining old-growth. Our study area was an intensively managed 40-80-year-old, second-growth or newly regenerating Alleghenynorthern hardwood forest. Continued reductions in large diameter trees may negatively impact future raccoon recruitment, especially in stands on 20-40-year rotations. Current forest management practices include leaving uncut riparian management zones (RMZ) along streams. These RMZs provide the potential for future large-diameter trees for maternal raccoon den sites. Intermediate silvicultural treatments and harvests can provide potential cavity trees via stem damage due to increased stand entry, skid trail construction, and general damage to standing trees through the tree felling process. 
Alternative treatments such as crown thinning or improvement cuttings would maintain stand quality and produce cavity trees for raccoons and other wildlife species. An uneven-aged harvest strategy, such as single-tree selection (Smith 1995), leaving certain stocking levels in all size classes also should produce quality timber while providing tree cavities. However, there are concerns over difficulty of application and its tendency, though delayed, to result in a shade-tolerant, mast-poor forest with less favorable wildlife attributes (Smith 1995). Reduction in hard mast producing species (i.e., Quercus spp.) will eliminate a significant food source during autumn and winter, further limiting habitat quality and raccoon abundance.

Species composition has not been reported as a significant factor in den tree selection (Stuewar 1943, Johnson 1970, Robb et al. 1996). Based on our results, tree cavity used was in proportion to availability; therefore, it appears that availability of tree cavities is more important than choosing a particular tree species. However, certain tree species are more prone to cavity development and therefore should be considered in forest management strategies. We found 30\% $(n=19)$ of all cavity trees used and $42 \%$ $(n=3)$ of all maternal dens were in yellow-poplar. Yellow-poplar was a common tree on the study area and is prevalent within forests throughout central West Virginia. Yellowpoplar is a fast-growing species and capable of producing large tree cavities because of its size and decay resistance. It is exceedingly common below $1000 \mathrm{~m}$ elevation based primarily on past disturbance events that favored it over other species.

During periods of adverse weather conditions raccoons will use dens that provide the best thermal microclimate to conserve energy. Rabinowitz and Pelton (1986) found warmer and more stable air temperatures in rock dens during the winter months 
compared to cavity trees. This may help explain an increase in rock den use during winter compared to spring and summer. Although not previously reported, log piles may provide similar thermal conditions to rock dens. In addition to warmer and more stable temperatures, rock dens and log piles may also allow for communal denning. Several researchers have reported the occurrence of communal denning during winter months for increased thermoregulation (Mech and Turkowski 1966, Endres and Smith 1993). We also found communal denning of 2 and 3 radio-collared individuals on four separate occasions in log piles and rock dens during winter and early spring. We also captured females with young during brief warm-periods in winter, suggesting a continued over winter familial bond and possible communal denning with young.

Intensive forest management on the MWERF reduced large cavity trees, and may increase raccoon use of rock dens. However, forest management practices can produce alternate den structures such as scrap log piles. On the MWERF, large log piles are formed during a timber harvest when stems are bucked and limbed and excess slash is piled next to log landings and often pushed over the side, covered with soil, and reseeded. Although covered, these log piles contain numerous available chambers, crevices, and potential den sites. Many of these log piles can measure up to several meters in length, width, and height. Although we were unable to fully quantify den size and number within each log pile, raccoons used these structures throughout the year on the MWERF. We speculate that log piles may support similar thermal microclimates as rock dens. The relative importance of $\log$ piles is uncertain. In forests where tree cavities are being reduced and rock den abundance is limited, log piles could serve as important, although temporary, alternate den sites. Log piles also may provide den sites for a variety of small 
and meso-mammals including opossums (Didelphis virginianus), striped skunks (Mephitis mephitis), red fox (Vulpes vulpes), gray fox (Urocyon cineroargenteus), and coyotes (Canis latrans), and even large mammals such as the black bear (Ursus americanus).

\section{Acknowledgments}

Funding was provided by USDA Forest Service Northeastern Research Station, Division of Forestry, West Virginia University, WV Cooperative Fish and Wildlife Research Unit US Geological Survey, MeadWestvaco Corporation, USDA/APHIS Wildlife Services, and West Virginia Division of Natural Resources. We would like to

thank our field technicians, H. Brace and J. Adams for their hard work and long hours. We also thank J. Johnson, J. Rodrigue, and J. Crum for field assistance and G. Seidel for statistical guidance.

\section{LITERATURE CITED}

Balcom, B. J., and R. H. Yahner. 1996. Microhabitat and landscape characteristics associated with the threatened Allegheny woodrat. Conservation Biology. 10:515-525.

Berner, A., and L. W. Gysel. 1967. Raccoon use of large tree cavities and ground burrows. Journal of Wildlife Management. 31:706-714.

Birch, G. L., G.A. Feldhamer, and W. G. Dyer. 1994. Helminths of the gastrointestinal tract of raccoons in Southern Illinois with management implications of Baylisascaris procyonis occurrence. Transactions of the Illinois State Academy of Science. 83:165-170.

Castleberry, S. B. 2000. Conservation and management of the Allegheny woodrat 
in the central Appalachians. Ph.D. Dissertation, West Virginia University, Morgantown. $166 \mathrm{pp}$.

DiGiovanni, D. M. 1990. Forest Statistics for West Virginia - 1975-1980. Northeastern Forest Experiment Station. Resource Bulletin NE-114.

Dorney, R. S. 1954. Ecology of marsh raccoons. Journal of Wildlife Management. $18: 217-225$.

Endres, K. M., and W. P. Smith. 1993. Influence of age, sex, season, and availability on den selection by raccoons within the central basin of Tennessee. American Midland Naturalist. 129:116-131.

Fajvan, M. A., S. T. Grushecky, and C. C. Hassler. 1998. The effects of harvesting practices on West Virginia's wood supply. Journal of Forestry. 96:33-39.

Fenneman, N. M. 1938. Physiography of the eastern United States. First edition. McGraw-Hill, New York, New York, USA. 714 pp.

Fritzell, E. K. 1978. Habitat use by prairie raccoons during the waterfowl breeding season. Journal of Wildlife Management. 42:118-127.

Johnson, S. A. 1970. Biology of the raccoon (Procyon lotor) in Alabama. Agricultural Experiment Station Auburn University Bulletin 402. 148 pp.

Kaufmann, J. H. 1982. Raccoon and Allies. Pages 567-585 in J. A. Chapman and G. A. Feldhamer, editors. Wild mammals of North America. John Hopkins University Press, Baltimore, Maryland. 1147 pp.

Kramer, M. T., R. J. Warren, M. J. Ratnaswamy, and B. T. Bond. 1999. Determining sexual maturity of raccoons by external versus internal aging criteria. Wildlife Society Bulletin. 27:231-234. 
Kreeger, T. J. 1996. Handbook of wildlife chemical immobilization. Wildlife Pharmaceuticals, Inc., Fort Collins, Colorado. 342 pp.

Lotze, J. H., and S. Anderson. 1979. Procyon lotor. Mammalian Species. 119:1-8.

McGarigal, K. and J. D. Fraser. 1984. The effect of forest stand age on owl distribution in southwestern Virginia. Journal of Wildlife Management. 44:1393-1398.

Mech, L. D., and F. Turkowski. 1966. Twenty-three raccoons in one winter den. Journal of Mammalogy. 47:529-530.

Nyland, R. D. 1996. Silviculture: Concepts and Applications. McGraw-Hill Series, Boston, Massachusetts. 633 pp.

Rabinowitz, A. R., and M. R. Pelton. 1986. Day-bed use by raccoons. Journal of Mammalogy. 67:766-769.

Robb, J. R., M. S. Cramer, A. R. Parker, and R. P. Urbanek. 1996. Use of tree cavities by fox squirrels and raccoons in Indiana. Journal of Mammalogy. 77:1017-1027.

Rosenberg, D. K., J. D. Fraser and D. F. Stauffer. 1988. Use and characteristics of snags in young and old forest stands in southwest Virginia. Forest Science. $34: 224-228$.

SAS Institute. 1999. SAS Institute, Cary, North Carolina.

Smith, D. Wm. 1995. The southern Appalachian hardwood region. in Regional Silviculture of the United States. J. W. Barrett editor. John Wiley \& Sons, Inc. New York, New York. 643 pp.

Stuewer, F. W. 1943. Raccoons: their habits and management in Michigan. Ecological Monographs. 13:203-257. 


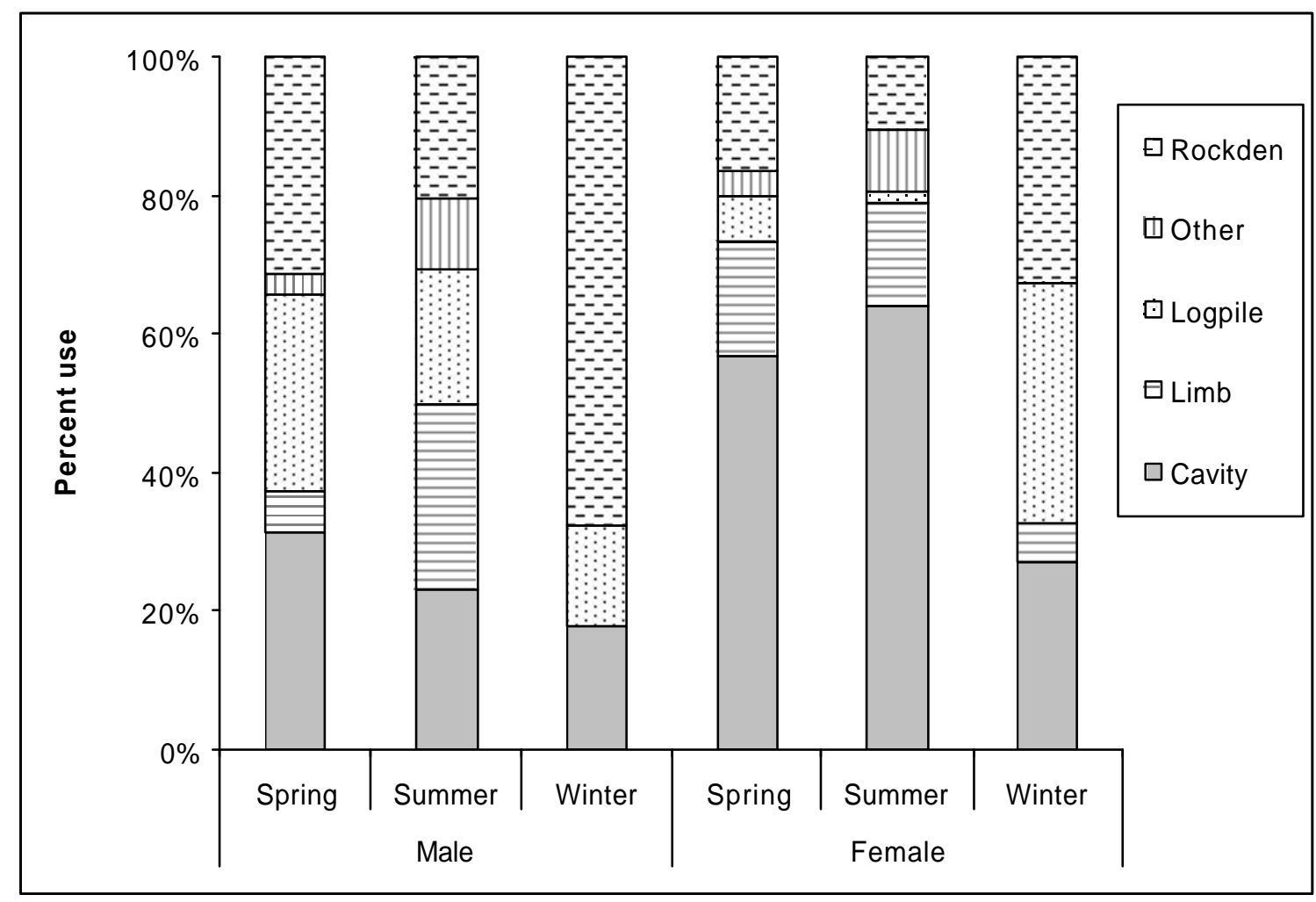

Figure 1. Relative frequency (\%) of den type use of raccoons (Procyon lotor) on the MeadWestvaco Wildlife and Ecosystem Research Forest, Randolph County, West Virginia, during 2001 to 2002. 


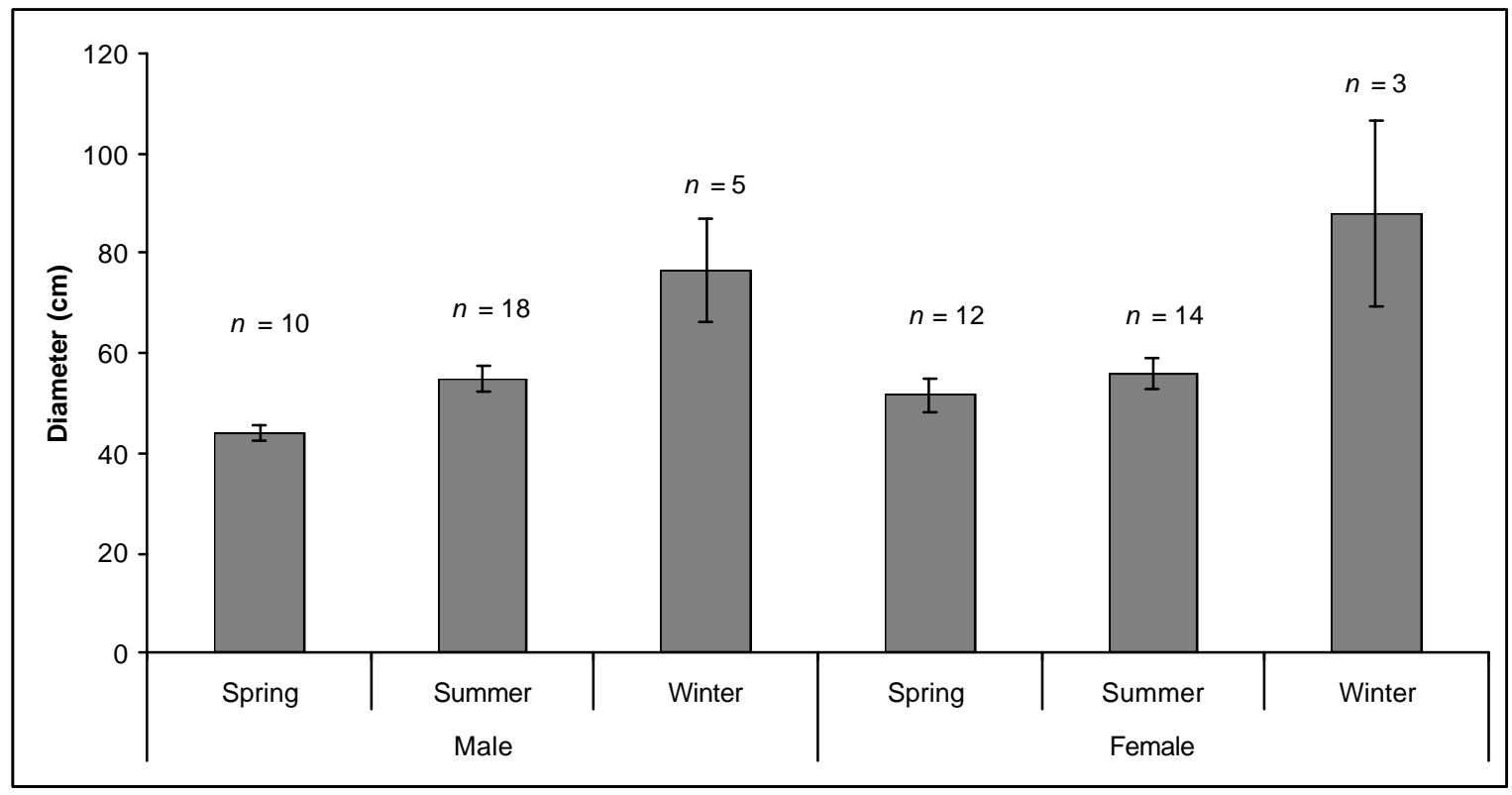

Figure 2. Mean diameter $( \pm \mathrm{SE})$ of cavity trees used by raccoons (Procyon lotor) on the MeadWestvaco Wildlife and Ecosystem Research Forest, Randolph County, West Virginia, during 2001 to 2002. 


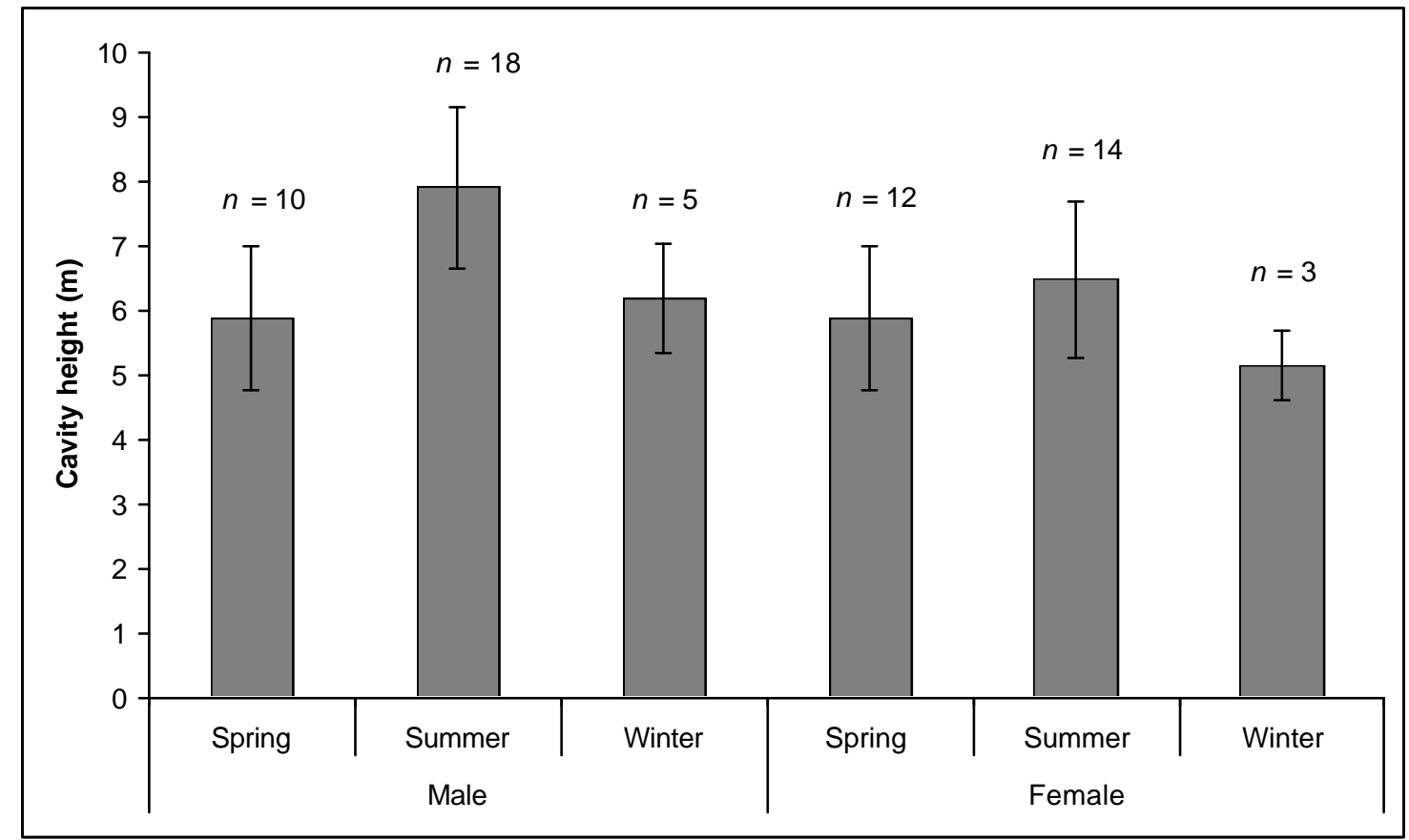

Figure 3. Mean cavity height ( $\pm \mathrm{SE}$ ) of cavity trees used by raccoons (Procyon lotor) on the MeadWestvaco Wildlife and Ecosystem Research Forest, Randolph County, West Virginia, during 2001 to 2002. 
Table 1. Relative frequency (total number) of diurnal den use by raccoons (Procyon lotor) among seasons on the MeadWestvaco Wildlife and Ecosystem Research Forest, Randolph County, West Virginia, during 2001 to 2002.

\begin{tabular}{|c|c|c|c|c|c|c|}
\hline \multirow[b]{2}{*}{ Den type } & \multirow[b]{2}{*}{ Spring } & \multicolumn{3}{|c|}{ Male $(n=19)$} & \multicolumn{2}{|c|}{ Female $(n=13)$} \\
\hline & & Summer & Winter & Spring & Summer & Winter \\
\hline Cavity & 11 & 18 & 5 & 17 & 43 & 10 \\
\hline Rock den & 11 & 16 & 19 & 5 & 7 & 12 \\
\hline Log pile & 10 & 15 & 4 & 2 & 1 & 13 \\
\hline Exposed limbs & 2 & 21 & 0 & 5 & 10 & 2 \\
\hline Other & 1 & 8 & 0 & 1 & 6 & 0 \\
\hline Total & 35 & 78 & 28 & 30 & 67 & 37 \\
\hline
\end{tabular}


Appendix A. Summary Statistics for raccoon den comparisons.

Table 1. Three-way ANOVA for cavity diameter at breast height.

\begin{tabular}{|l|c|c|c|}
\hline & $d f$ & $F$ value & Pr $>F$ \\
\hline Year & 1 & 8.48 & 0.0054 \\
\hline Gender & 1 & 1.03 & 0.3160 \\
\hline Season & 3 & 10.53 & $<0.0001$ \\
\hline Year*Gender & 1 & 0.48 & 0.4918 \\
\hline Year*Season & 2 & 0.01 & 0.9856 \\
\hline Gender*Season & 2 & 0.52 & 0.5970 \\
\hline Year*Gender*Season & 1 & 0.60 & 0.4438 \\
\hline
\end{tabular}

Table 2. Three- way ANOVA for cavity height.

\begin{tabular}{|l|c|c|c|}
\hline & $d f$ & $F$ value & Pr $>F$ \\
\hline Year & 1 & 3.93 & 0.0530 \\
\hline Gender & 1 & 0.96 & 0.7241 \\
\hline Season & 3 & 1.49 & 0.2347 \\
\hline Year*Gender & 1 & 0.42 & 0.5222 \\
\hline Year*Season & 2 & 2.76 & 0.0732 \\
\hline Gender*Season & 2 & 0.44 & 0.6467 \\
\hline Year*Gender*Season & 1 & 0.30 & 0.5874 \\
\hline
\end{tabular}


Table 3. Loglinear regression for diurnal den site selection.

\begin{tabular}{|l|c|c|c|}
\hline Source & $d f$ & Chi-Square & Pr > ChiSQ \\
\hline Year & 2 & 30.06 & $<0.0001$ \\
\hline Gender & 1 & 0.01 & 0.9201 \\
\hline Season & 2 & 5.77 & 0.0559 \\
\hline Gender*Season & 2 & 1.38 & 0.5010 \\
\hline Type & 4 & 16.22 & 0.0027 \\
\hline Gender*Type & 4 & 19.17 & 0.0007 \\
\hline Season*Type & 8 & 26.62 & 0.0008 \\
\hline Gender*Season*Type & 8 & 15.61 & 0.0483 \\
\hline Likelihood Ratio & 28 & 60.62 & 0.0003 \\
\hline
\end{tabular}




\section{Chapter 3}

Occurrence of raccoon roundworm in raccoons in central West Virginia: implications for Allegheny woodrat conservation

SHELDON F. OWEN, Wildlife and Fisheries Resources, Division of Forestry, West Virginia University, Morgantown, WV 26506-6125, USA, 304-293-2941, sowen1@ mix.wvu.edu

JOHN W. EDWARDS, Wildlife and Fisheries Resources, Division of Forestry, West Virginia University, Morgantown, WV 26506-6125, USA, 304-293-2941, jedwards@wvu.edu

W. MARK FORD, USDA Forest Service, Northeastern Forest Experiment Station, Fernow Experimental Forest, Box 404, Parsons, WV 26287, USA, 304-478-2000, mford@fs.fed.us

JAMES M. CRUM, West Virginia Division of Natural Resources, Elkins, WV 26241, USA, 304-637-0245, jcrum@dnr.state.wv.us

PETRA BOHALL WOOD, West Virginia Cooperative Fish and Wildlife Research Unit, US Geological Survey, Division of Forestry, West Virginia University, Morgantown, WV 26506-6125, USA, 304-293-2941, pbwood@wvu.edu

\footnotetext{
ABSTRACT

We investigated the occurrence of raccoon roundworm (Baylisascaris procyonis) in raccoons (Procyon lotor) in the Allegheny Mountains of West Virginia. We found no evidence of $B$. procyonis infection in 25 raccoons sampled by fecal floatation and necropsy methodologies. On the basis of our 25 negative cases at a $95 \%$ confidence level the estimated non-detectable maximum constant prevalence rate is $8 \%$. Baylisascaris procyonis has been implicated in population declines of the Allegheny woodrat (Neotoma magister) in the northeastern United States. The low prevalence of $B$. procyonis in an area inhabited by what is believed to be a
} 
stable population of Allegheny woodrats supports conservation measures to monitor anthropogenic activities that may increase the prevalence of $B$. procyonis or raccoon interaction with Allegheny woodrats.

\section{INTRODUCTION}

The raccoon is the definitive host for Baylisascaris procyonis. Because B. procyonis is asymptomatic in raccoons and a low pathogenic risk, it is not considered a limiting factor in raccoon populations (Davidson and Nettles 1997). However, B. procyonis can infect and cause serious central nervous system disease in 19 mammalian and 13 avian species, including the Allegheny woodrat (Kazacos and Boyce 1989).

The Allegheny woodrat is found in the central and southern Appalachians in close association with rocky habitats, cliffs, caves, and rock-outcrops (Hall 1981, Castleberry et al. 2001). It is monitored by the Natural Heritage Program (Association for Biodiversity Information 1999) as rare in parts of its range but globally secure (G3/G4). The Allegheny woodrat also is considered endangered, threatened or a species of concern in every state in which it occurs (Castleberry 2000). Woodrats display caching behavior, including feces of other animals; they often consume the seeds and plant material contained in the feces. Accordingly, woodrats are particularly susceptible to B. procyonis infection when they collect infected raccoon feces (Birch et al. 1994, LoGuidice 2003).

Increased urbanization and habitat modification/fragmentation have resulted in higher raccoon densities and have altered patterns of habitat use at the regional scale (Hoffman and Gottschang 1977, Linscombe 1993, Riley et al. 1998). These changes in raccoon spatial distribution and increased densities may have increased interactions with Allegheny woodrat populations, thereby elevating the risk of $B$. procyonis infection. Researchers in the northeastern 
United States have attributed population declines of the Allegheny woodrat in part to fatal exposure to B. procyonis (Birch et al. 1994, LoGiudice 2003). Information on the geographic distribution and prevalence of B. procyonis is important to the parasite epizootiology and woodrat conservation.

Although considerable research has been conducted to determine the ecology and conservation status of the Allegheny woodrat in the central Appalachians (Castleberry 2000, Castleberry et al. 2001), only two studies have investigated the presence of B. procyonis within West Virginia; one of 58 raccoon scats collected from occupied woodrat habitat in Monongalia and Preston Counties contained nematode eggs compatible with B. procyonis (pers. comm., J. Wright, Carlisle, PA); and, 2 of 5 raccoons examined at necropsy from a suburban environment (Ohio County) in an area of no known woodrat occurrence were found infected with $B$.

procyonis (Schaffer et al. 1981). Consequently, our objective was to determine the prevalence of B. procyonis in an area of known Allegheny woodrat and raccoon sympatry in West Virginia. Moreover, we discuss possible factors affecting raccoon populations and their implications for Allegheny woodrat conservation.

\section{Parasite life cycle}

Baylisascaris procyonis is a large nematode from the order Ascaridoidea. Infection occurs when raccoons or an intermediate host ingest embryonated eggs. In raccoon infection, a young raccoon ingests the infective egg, the larva hatches, penetrates the intestine, and migrates to the liver, then lungs, where it is expectorated and then re-swallowed. Adult B. procyonis reside in the small intestine where eggs are transported in the feces to the environment allowing the life cycle to reinitiate in a new host. Although generally considered a low pathanogenic risk in raccoons, B. procyonis can cause intestinal obstruction and rupture when the parasite load is 
high. Stone (1983) reported two juvenile raccoon mortalities resulting from intestinal obstruction from 636 and 141 B. procyonis. Because of age-related resistance, adult raccoons must consume the encysted larvae from an intermediate host to become infected. The larval migration route in adult raccoons then follows the same migration routes as in juvenile raccoons.

Baylisascaris procyonis can complete its life cycle in both juvenile and adult raccoons, but only molts to the L3 stage in intermediate hosts (i.e., there is no further development). Female B. procyonis can produce from thousands to millions of eggs per day. At such rates, habitats can quickly become contaminated and pose a high risk to other animals sharing the environment. Baylisascaris spp. eggs also are resistant to extreme environmental conditions and can remain infective in the soil for 3 to 5 years (Kazacos 1983).

In intermediate host infection, an animal ingests an infective egg, the larva hatches, penetrates the intestines, migrates to the liver and lungs, and then to other tissues of the body. Baylisascaris procyonis has been found to migrate and encyst in tissues of the chest and cephalic regions including the central nervous system of the intermediate host (Kazacos 1983). Baylisascaris procyonis infections can cause fatal neurological diseases in intermediate hosts including humans (Davidson and Nettles 1997), with mortality increasing with degree of environmental contamination (Kazacos 1983, LoGuidice 2003). Encysted larvae found within tissues are the most common diagnosis of infection in intermediate hosts. Baylisascaris procyonis abundance is believed to be more dependent on raccoon density than on the density of intermediate hosts because of the number of different intermediate hosts. Therefore, raccoons can serve as a disease reservoir, continuously reintroducing the parasite to intermediate hosts and young raccoons (LoGiudice 2003). Other Baylisascaris spp. also are found in wildlife populations such as B. transfuga in black bears (Ursus americanus) and B. columaris in striped 
skunks (Mephitis mephitis) (Davidson and Nettles 1997). The potential for Allegheny woodrat exposure to Baylisascaris spp. also should be considered in areas of black bear or striped skunk sympatry.

\section{METHODS}

We conducted this study on the MeadWestvaco Ecosystem Research Forest (MWERF) located in the Allegheny Plateau physiographic province in Randolph County, West Virginia (Fenneman 1938). The MWERF is a 3,600 ha intensively managed forest dedicated to the study of the interaction of industrial forestry with Appalachian ecosystems. Elevations range from 700 $\mathrm{m}$ to $1,200 \mathrm{~m}$ with steep side-slope mountains, broad ridge tops, and narrow valleys. Annual precipitation averages between 170 and $190 \mathrm{~cm}$ (Smith 1995). The MWERF is a 40-80 year old, second-growth or newly regenerating Allegheny-northern hardwood forest dominated by black cherry (Prunus serotina), sugar maple (Acer saccharum), red maple (A. rubrum), yellow birch (Betula alleghaniensis), American beech (Fagus grandifolia), and northern red oak (Quercus rubra) and is characterized by a cool, moist climate. Allegheny woodrats are abundant in rocky areas and outcroppings on the MWERF and the population appears to be stable (Castleberry 2000).

Raccoon fecal samples were collected from trapped individuals $(25 \times 25 \times 81 \mathrm{~cm}$ Havahart cage traps; Woodstream Corp., Lititz, PA) during spring ( $n=16$ : April - June) and fall ( $n=9$ : September - December) 2001 and 2002, packaged in plastic bags, and refrigerated until analysis. We used a fecasol® solution (1.2 specific gravity) and fecalyzer® (EVSCO Pharmaceuticals, Buena, NJ) to identify endoparasite eggs via the fecal floatation technique described in Sloss (1970). We prepared fixed samples of identified species for confirmation and photographed all parasite species for further verification. 


\section{RESULTS AND DISCUSSION}

We found no evidence of B. procyonis eggs from 18 adult raccoons (12 male; 6 female) and four juvenile raccoons ( 3 male; 1 female) sampled by fecal flotation. We also found no evidence of adult B. procyonis in the small intestine of one juvenile-male and two adult-male road-kill raccoons via necropsy. However, Capillaria sp. eggs were detected in 28\% (7) and Strongyloides sp. eggs were detected in 64\% (16) of individuals. We estimated the raccoon population on our study area to be approximately 54 individuals $\left(1.5\right.$ raccoons $\left./ \mathrm{km}^{2} \times 36 \mathrm{~km}^{2}\right)$. On the basis of our 25 negative cases at a $95 \%$ confidence level the estimated non-detectable maximum constant prevalence rate is $8 \%$ and the maximum number of detectable cases within the population of 54 raccoons would be five (Corn and Nettles 1995). Fecal flotation to detect $B$. procyonis is a reliable indicator of infection, with as many as $25,750( \pm 3,912)$ eggs per gram of feces reported (Jacobson et al. 1976). We are therefore confident that the prevalence of $B$. procyonis on our study area is below $8 \%$ and possibly as low as zero. Baylisascaris procyonis is known to occur in Ohio County, West Virginia (Schaffer et al. 1981) and neurological disease from Baylisascaris sp. larval migrans is known to occur in woodchuck (Marmota monax) from Marion county, West Virginia (unpubl. data, J. Crum, Elkins, WV). Both areas are more urban and located considerable distance $(>50 \mathrm{~km})$ north and west of our study area in Randolph County.

The geographic distribution of B. procyonis is coincident with the distribution of raccoons in the continental United States. However, researchers have reported various prevalence rates of B. procyonis throughout the range and have found higher prevalence rates in juvenile than adult raccoons in the Northeast and mid-West (Kazacos 1983, Ermer and Fodge 1986). Kazacos (1983) found rates of $70 \%$ in adults and $88 \%$ in juveniles in Indiana while 
Ermer and Fodge (1986) reported 38\% of adults and $90 \%$ of juveniles infected with B. procyonis in New York. Other authors have reported infection rates of $80 \%, 43 \%$, and $20 \%$ in Iowa (Kazacos 1983), Kentucky (Cole and Shoop 1987), and West Virginia (Schaffer et al. 1981), respectively. Direct transmission between raccoons, prolonged viability of shed eggs, and the infection of intermediate hosts by B. procyonis contribute to its ability to persist at low raccoon population densities.

Recent Allegheny woodrat population declines in the northern and western peripheries of its range have been attributed in part to the fatal exposure to B. procyonis and to habitat loss from forest fragmentation (Birch et al. 1994, Balcolm and Yahner 1996). Current land use practices have altered raccoon spatial distribution and movements and also have increased raccoon abundance. Therefore, land management practices may have forced or expanded raccoon populations into habitats occupied by Allegheny woodrats (Balcolm and Yahner 1996). This increased association may elevate parasite contamination and thus increase the possibility of woodrat infection with B. procyonis. LoGuidice (2003) reported 100\% mortality of Allegheny woodrats experimentally released at sites infested with B. procyonis in the Kittatinny Range of northwestern New Jersey and in the Shawangunk Mountains of southeastern New York. Because the MWERF is an intensively managed forest, habitat fragmentation and the reduction in cavity trees may result in increased raccoon and woodrat interaction. Owen et al. (Chapter 2) found radio-collared raccoons denning in 6 rock outcrops that contained Allegheny woodrats or exhibited evidence of past use. Even where tree cavities are not limited, raccoons appear to select rock outcrops to den during certain seasons (Endres and Smith 1993).

The likelihood of woodrats encountering infected raccoons or raccoon feces is greater where raccoon densities are high (Castleberry 2000). Habitat quality for raccoons in the high 
Allegheny Mountain region of West Virginia is considered poor to fair (Rogers 2000) and the raccoon rabies epizootic advance west of the Allegheny Mountains in the past five years may have depressed raccoon populations. Low density and spatial dispersion of raccoons on the MWERF may reduce the likelihood of direct and indirect interactions between raccoons and woodrats, and therefore B. procyonis infection.

Raccoon resistance to $B$. procyonis infection is believed to increase with age, however, direct transmission is possible in young raccoons (Davidson and Nettles 1997). The natal dispersal of raccoons introduces a possible mechanism of infecting new raccoons and woodrat populations in distant geographic locations. Moreover, the anthropogenic translocation of raccoons (interstate or intrastate transport) from areas of high B. procyonis prevalence may pose threats to Allegheny woodrat populations. Our findings support conservation measures to monitor anthropogenic activities that may increase the prevalence of B. procyonis or raccoon interaction with Allegheny woodrats.

\section{ACKNOWLEDGMENTS}

Funding was provided by USDA Forest Service Region 9 and Northeastern Research Station, West Virginia University, Division of Forestry, WV Cooperative Fish and Wildlife Research Unit US Geological Survey, MeadWestvaco Corporation, USDA/APHIS Wildlife Services, and West Virginia Division of Natural Resources funds from Federal Aid in Wildlife Restoration, Project W-48--18. We would like to thank our field technicians, H. Brace and J. Adams for their hard work and long hours.

\section{LITERATURE CITED}

Association for Biodiversity Information. 1999. Downloadable data sets. http://www.abi.org/. 
Natural Heritage Central Databases. Association for Biodiversity Information, Arlington, Virginia, USA.

Balcom, B. J., and R. H. Yahner. 1996. Microhabitat and landscape characteristics associated with the threatened Allegheny woodrat. Conservation Biology. 10:515-525.

Birch, G. L., G.A. Feldhamer, and W. G. Dyer. 1994. Helminths of the gastrointestinal tract of raccoons in Southern Illinois with management implications of Baylisascaris procyonis occurrence. Transactions of the Illinois State Academy of Science. 83:165-170.

Castleberry, S. B. 2000. Conservation and management of the Allegheny woodrat in the central Appalachians. Ph.D. Dissertation, West Virginia University, Morgantown. $166 \mathrm{pp}$.

Castleberry, S. B., W. M. Ford, P. Bohall Wood, N. L. Castleberry, and M. T. Mengak. 2001. Movements of Allegheny woodrats in relation to timber harvesting. Journal of Wildlife Management. 65:148-156.

Cole, R. A., and W. L. Shoop. 1987. Helminths of the raccoon (Procyon lotor) in Western Kentucky. Journal of Parasitology. 73:762-768.

Corn, J. L., and V. F. Nettles. 1995. Disinfection in Wildlife. Revue scientifique et technique: Office international des epizooties. 14:455-468.

Davidson, W. R., and V. F. Nettles. 1997. Field manual of wildlife diseases in the Southeastern United States. Southeastern Cooperative Wildlife Disease Study. 417 pp.

Emer, E. M., and J. A. Fodge. 1986. Occurrence of the raccoon roundworm in raccoons in Western New York. New York Fish and Game Journal. 33:58-61.

Endres K. M., and W. P. Smith. 1993. Influence of age, sex, season and availability on den 
selection by raccoons within the Central Basin of Tennessee. American Midland Naturalist. 129:116-131.

Fenneman, N. M. 1938. Physiography of the eastern United States. First Edition. McGraw-Hill, New York, New York, USA. 714 pp.

Hall, E. R. 1981. The mammals of North America. Second Edition. John Wiley and Sons, New York, New York, USA.

Hoffman, C. O., and J. L. Gottschang. 1977. Numbers, distribution, and movements of a raccoon population in a suburban residential community. Journal of Mammalogy. 58:623-636.

Jacobson H. A., P. F. Scanlon, V. F. Nettles, and W. R. Davidson. 1976. Epizootiology of an outbreak of cerebrospinal nematodiasis in cottontail rabbits and woodchucks. Journal of Wildlife Disease. 12:357-360.

Kazacos, K. R. 1983. Raccoon roundworms (Baylisascaris procyonis)- A cause of animal and human disease. Station Bulletin 442. Perdue University Agricultural Experiment Station. $25 \mathrm{pp}$.

Kazacos, K. R., and W. M. Boyce. 1989. Zoonosis update: Baylisascaris larva migrans. Journal of the American Veterinary Medical Association. 195:894-903.

Linscombe, G. 1993. U. S. fur harvest (1970-1992) and fur value (1974-1992) statistics by state and region. Fur Resources Commission, International Association of Fish and Wildlife Agencies, Washington, D. C., USA.

LoGiudice, K. 2003. Trophically transmitted parasites and the conservation of small populations: raccoon roundworm and the imperiled Allegheny woodrat. Conservation Biology. 17:258-266. 
Riley, S. P., D. J. Hadidian, and D. A. Manski. 1998. Population density, survival, and rabies in raccoons in an urban national park. Canadian Journal of Zoology. 76:1153-1164.

Rogers, R. 2000. West Virginia raccoon field trial survey 1999-2000. West Virginia Division of Natural Resources, Romney, West Virginia. $11 \mathrm{pp}$.

Schaffer G. D., W. R. Davidson, V. F. Nettles, and E. A. Rollor III. 1981. Helminth parasites of translocated raccoons (Procyon lotor) in the Southeastern United States. Journal of Wildlife Diseases. 17:217-227.

Sloss, M. W. 1970. Clinical Veterinary Parasitology. Iowa State University Press. Ames, Iowa. $450 \mathrm{pp}$.

Smith, D. Wm. 1995. The southern Appalachian hardwood region. in Regional Silviculture of the United States. J. W. Barrett editor. John Wiley \& Sons, Inc. New York, New York. $643 \mathrm{pp}$.

Stone, W. B. 1983. Intestinal obstruction in raccoons caused by the ascarid Baylisascaris procyonis. New York Fish and Game Journal. 30:117-118. 


\section{Chapter 4}

\section{Raccoon spatial requirements and their implications for the Appalachian Ridge Oral Rabies Vaccination Program}

SHELDON F. OWEN, Wildlife and Fisheries Resources, Division of Forestry, West Virginia

University, Morgantown, WV 26506-6125, USA, 304-293-2941, sowen1 @ mix.wvu.edu

JOHN W. EDWARDS, Wildlife and Fisheries Resources, Division of Forestry, West Virginia

University, Morgantown, WV 26506-6125, USA, 304-293-2941, jedwards@wvu.edu

JAMES M. CRUM, West Virginia Division of Natural Resources, Elkins, WV

26241, USA, 304-637-0245, jcrum@dnr.state.wv.us.

W. MARK FORD, USDA Forest Service, Northeastern Fore st Experiment Station, Fernow

Experimental Forest, Box 404, Parsons, WV 26287, USA, 304-478-2000,

mford@fs.fed.us

\section{INTRODUCTION}

Raccoons (Procyon lotor) are vectors for rabies and are considered a major public health concern because of frequent interactions with humans, domestic pets, and livestock. A raccoon rabies epizootic began in the mid-Atlantic States in 1977 and positive rabies cases peaked in 1983 (Hubbard 1985, Torrence et al. 1992). Although the number of reported cases declined thereafter, the geographic distribution of positive rabies cases has increased (Torrence et al. 1992). The first rabies case in West Virginia from this epizootic was reported in 1977 in the eastern panhandle along the Virginia border (Hubbard 1985). Since that time the epizootic has spread westward across West Virginia; however, the spread rate has slowed somewhat crossing the Allegheny Mountains. The spread of rabies in relation to raccoon movements is of considerable interest to wildlife managers and public health professionals, and therefore 
knowledge of raccoon population densities and spatial requirements would be useful in formulating rabies management strategies.

In the fall of 2001, the West Virginia Department of Health and Human Resources in association with USDA/APHIS Wildlife Services, West Virginia Division of Natural Resources, and the Centers for Disease Control began a raccoon oral rabies vaccination program along the Appalachian Mountains. The rabies vaccination program has dropped 800,000 baits along a 24$48 \mathrm{~km}$ wide corridor in central West Virginia, extending from the northern panhandle to the southern coalfields. Coinciding with the application of vaccination baits, USDA/APHIS Wildlife Services is conducting regional population estimates based on trapping and bait effectiveness from serologic rabies surveillance. Information on the homerange requirements and spatial patterns of raccoons could be used to effectively focus the target area to increase the likelihood of visitation and possibly reduce the number of baits and cost requirements for a successful vaccination program. Spatial requirement data also could provide information to help predict current and future exposure and contact rates among raccoons. Accordingly, our objectives were to monitor raccoon spatial movements within the higher elevations of the Allegheny Mountains and to relate our findings to the ongoing oral rabies vaccination project in the central Appalachians.

\section{Background}

Rabies is an acute infectious viral disease classified as a Rhabdovirus. Rabies infects the central nervous system of mammals and generally persists in nature as a salivary gland infection of carnivorous animals (Sikes 1981). All mammals are susceptible, but rabies is much more common in omnivores and carnivores (Davidson and Nettles 1997). Animals become infected via the bite of an infected animal or by the exposure of fresh wounds to the saliva of an infected 
animal (Sikes 1981, Davidson and Nettles 1997). The rabies virus spreads through the nerves to the spinal cord and brain. There are no specific gross lesions associated with rabies, however clinical signs include altered behavior, incoordination, lethargy, and paralysis (Davidson and Nettles 1997). Rabies epidemics can result in substantial mortality in areas of high population densities. Rabies is probably the most commonly known wildlife disease because of its $100 \%$ fatality rate in humans and ongoing pet vaccination campaigns (Davidson and Nettles 1997).

The most common rabies epizootic associates are domestic dogs (Canis familiaris), red fox (Vulpes vulpes), gray fox (Urocyon cinereoargenteus), striped skunk (Mephitis mephitis), coyotes (Canis latrans), raccoons, and bats (Chiroptera) (Sikes 1981, Davidson and Nettles 1997). In the United States, historical associations for specific wildlife reservoir hosts in certain geographic areas exist: red foxes in New England and the Northeast; raccoons in the Southeast; skunks in the Midwest and South-central states; and bats reported from 46 of the 48 contiguous states (Carey 1985, Davidson and Nettles 1997). However these associations are changing, evidenced by the eruption of raccoon rabies throughout the mid-Atlantic States since the early 1970’s (Carey 1985, Davidson and Nettles 1997).

Free-ranging raccoons have been successfully vaccinated against rabies. Rabies vaccination programs in parts of Europe and Canada have prevented potential epizootic outbreaks of rabies in raccoons and other species (Davidson and Nettles 1997, Rosatte et al. 2001). Plastic packets of oral rabies vaccines (RM Raboral V-RG®, Artemis Technologies Inc., Canada) are encapsulated within fishmeal/polymer baits are spread along the leading edge of rabies spread within a region. Unvaccinated animals are inoculated by eating this vaccine packet. 


\section{STUDY AREA}

Our study was centered on the 3630 ha MeadWestvaco Corporation's Wildlife and Ecosystem Research Forest (MWERF) located in the Allegheny Mountain and Plateau physiographic sub-province in Randolph County, West Virginia. The MWERF is an intensively managed forest dedicated to the study of the interaction of industrial forestry with Appalachian ecosystems. Elevations range from $700 \mathrm{~m}$ to $1200 \mathrm{~m}$ with steep side-slope mountains, broad ridge tops, and narrow valleys. The underlying geologic material is primarily Pottsville series shale and sandstone, along with limestone (Fenneman 1938). Emergent rock outcrops formed along mountain ridgelines as shale eroded and the more resistant sandstone remained. The climate is cool and moist, with a growing season of 150 days (Smith 1995). The MWERF is a second- and third-growth Allegheny-northern hardwood forest dominated by black cherry (Prunus serotina), sugar maple (Acer saccharum), red maple (A. rubrum), yellow birch (Betula alleghaniensis), American beech (Fagus grandifolia), and northern red oak (Quercus rubra) except in higher elevations that are characterized by red spruce (Picea rubens) and Eastern hemlock (Tsuga canadensis) communities. Riparian areas are characterized by the aforementioned tree species and rosebay rhododendron (Rhododendron maximum).

\section{METHODS}

We used $38 \times 38 \times 105 \mathrm{~cm}$ and $25 \times 25 \times 80 \mathrm{~cm}$ cage traps $\left(\right.$ Havahart ${ }^{\circledR}$, Woodstream Corporation, Lititz, PA) baited with sardines, marshmallows, and forms of rancid meats to livetrap raccoons. We chemically immobilized trapped raccoons with $30 \mathrm{mg} / \mathrm{kg}$ Ketamine plus 4 $\mathrm{mg} / \mathrm{kg}$ Xylazine (Kreeger 1999). Yohimbine $(0.15 \mathrm{mg} / \mathrm{kg}$ ) was used as an antagonist to Xylazine. Once immobilized, raccoons were aged (juvenile or adult) and sexed based on

external characteristics (Johnson 1970, Kramer et al. 1999). Each individual was ear-tagged with 
a uniquely numbered Jiffy size 3 aluminum tag (National Band and Tag Co., Newport, KY) and weighed. We also recorded total length, ear length, and hind-foot length measurements. Adult males and females were equipped with mortality sensitive radio collars (Advanced Telemetry Systems, Asanti, MN; AVM Instrument Company, Ltd., Colfax, CA). Radio collars weighed approximately 70 grams and had a battery life of 18 months. We only tagged adults to avoid dispersing sub-adults leaving the study area. To estimate population density of raccoons, we selected a $3 \mathrm{~km}^{2}$ portion characteristic of the study area to conduct trapping surveys that included 50 live traps over a 10-night period during spring and fall 2002 (USDA/APHIS Wildlife Services trapping protocol, unpublished). We compared homerange size to determine season- and genderspecific differences using a three-way ANOVA.

\section{Radio Telemetry}

We monitored radio-tagged individuals nightly with Wildlife Materials TRX-2000S receivers (Wildlife Materials Inc., Carbondale, IL) and 3-element Yagi antennas to determine spatial locations. We conducted nocturnal triangulation (simultaneous and individual observer) from approximately 1 hour after sunset until 1 hour after sunrise with a 3-hour time interval between consecutive locations to reduce autocorrelation. To reduce telemetry error, we recorded telemetry bearings from as near the animal as possible, and minimized the temporal interval $(<5$ $\min$ ) of $=2$ bearings. We radio-tracked raccoons over spring/summer (April- August) and fall/winter (September-January) time-periods. We used only individual raccoons with $>30$ locations to determine homerange and habitat selection. To determine UTM coordinates of the estimated locations, we entered the UTM coordinates of known telemetry stations and locational bearings into the program LOCATE. The LOCATE output location UTM coordinates then were entered into the Animal Movement Analysis Extension (Hooge and Eichenlaub 1997) in 
ArcView® (Environmental Systems Research Institute, Redlands, California) where we determined the 95\% AKM homerange estimate. Using Arcview/GIS we buffered streams at 100 $m$ intervals to evaluate active locations in relation to streams. We compared active locations along an elevational gradient to assess activity areas where bait drops could be most effectively targeted. We also determined spatial guidelines based on raccoon movements and geographical parameters.

\section{RESULTS}

We radio-tagged and monitored 42 adult raccoons from fall 2000 through spring 2002. Sufficient locations (>30 locations) were obtained from 13 females (5 fall; 8 summer) and 17 males ( 6 fall; 11 summer) to determine homerange area and compare spatial requirements. Mean homerange size differed among years $(F=5.66, d f=1, P=0.025)$ however, there were no significant interactions between year and any other variable so year was used as a blocking factor. Mean homerange size differed between gender $(F=8.76, \mathrm{df}=1, P=0.007)$ but not seasons $(F=0.05, d f=1, P=0.826)$ and there was no interaction between gender and season $(F$ $=0.07, d f=1, P=0.797)$. Mean female homerange size was 244 ha (range, $105-582, \mathrm{SE}=$ 38.0), whereas, mean male homerange size was 394 ha (range, $140-702$, SE = 40.7). We estimated raccoon density on the MWERF as 1.5 raccoons $/ \mathrm{km}^{2}$. We found $13 \%$ of all active locations to be below $800 \mathrm{~m}$ in elevation and $55 \%$ and $92 \%$ of the active locations below $900 \mathrm{~m}$ and $1000 \mathrm{~m}$ respectively (Fig. 1). According to the stream buffer analysis, we found $63 \%$ of all active locations to be within $200 \mathrm{~m}$ of a steam and $82 \%, 92 \%$, and $98 \%$ of all active locations to be within $300 \mathrm{~m}, 400 \mathrm{~m}$, and $500 \mathrm{~m}$ respectively (Fig. 2). 


\section{DISCUSSION}

The westward spread of raccoon rabies in West Virginia has been much slower than the spread to the northeast, probably in response to lower raccoon population density in the Allegheny Mountains. Lower densities are due in part to unsuitable habitat within the higher elevations of the Allegheny Mountains (Rogers 2000). On our study site, elevations ranged from 600 to $1100 \mathrm{~m}$ with contrasting habitats of Allegheny hardwoods in the lower elevations and Eastern hemlock and red spruce forests in the highest elevations. Because of the near absence of mast producing species at the higher elevations, these habitats are least selected by raccoons. For example, we found $92 \%$ of all active locations below 1000 m elevation.

Raccoons are commonly associated with water and their movements are considered to be restricted by proximity to free water (Johnson 1970, Lotze and Anderson 1979, Kaufman 1982). We found $92 \%$ of all foraging locations to be within $400 \mathrm{~m}$ of a stream. Moreover, some portion of the homerange of all radio-transmittered raccoons fell within $400 \mathrm{~m}$ of a stream. Focusing bait drop within specific stream buffers would substantially reduce the target area while maintaining contact with all individuals.

Although only sufficiently tested in foxes, effectively immunizing $70 \%$ of the targeted population has been generally reported to achieve sufficient anti-rabies population immunity (Bacon 1995). Restructuring the bait-drop area on our study site to include an elevational ceiling of $1000 \mathrm{~m}$ and focusing the drop zone to within $400 \mathrm{~m}$ on either stream bank to target $92 \%$ of the nocturnal activity, would effectively reduce the bait-drop area by $36 \%$ (Fig. 3), while maintaining $>70 \%$ contact with all animals. Targeting $82 \%$ of the nocturnal activity within 300 $\mathrm{m}$ of a stream, while maintaining the elevational ceiling of $1000 \mathrm{~m}$ would further reduce the baitdrop area by $62 \%$ (Fig. 3) and contact $>70 \%$ of the raccoon population. 
Applying these same parameters of $1000 \mathrm{~m}$ elevation and within $400 \mathrm{~m}$ of a stream would reduce the bait drop area at the county (Randolph) level by 22\% (Fig. 4). For Randolph County, a single elevation parameter of below $1000 \mathrm{~m}$ elevation would reduce the bait area by 33\%. At the landscape level, the MWERF is characteristic of the Allegheny Mountain region throughout central West Virginia. Applying an elevation parameter $(1000 \mathrm{~m})$ along this region would significantly reduce the bait area and would focus distribution in areas of increased activity (Fig. 5). However, a blanket approach may not be effective based on changes in habitat associations and raccoons densities across the Allegheny Mountain landscape. Nonetheless, approximately $100 \%$ of the raccoons were encountered within this elevation parameter and based on unsuitable habitat above $1000 \mathrm{~m}$ elevation it is possible to vaccinate $>70 \%$ of the population below $1000 \mathrm{~m}$. Considering the logistics of aerial bait disbursement, flight lines along streams may not be efficient or pragmatic. However, this applied design may be more appropriate within localized areas where aerial drops are restricted and baits are hand-distributed by field personnel.

On a local scale, raccoons selected intact forests and diameter-limit harvested stands during the fall season (Chapter 1) coinciding with mast fall. Wildlife disease personnel could also focus efforts in these vegetation types thereby increasing the likelihood that raccoons will encounter and consume the vaccine. Natural resource managers must also consider the habitat changes from a rural environment (MWERF) to an urban setting. Not only will habitat associations change, but raccoon densities also may increase with access to sources of supplemental food from gardens and human refuse that increase carrying capacity.

Bait densities should be tailored to regional target and non-target population densities (Hable et al. 1992). Reported bait-densities have varied in relation to geographic location and population density estimates. Approximate bait-densities of 1.2 baits $/ \mathrm{ha}\left(120 / \mathrm{km}^{2}\right)$ achieved 
76\% acceptance rates in Pennsylvania and Virginia (Rupprecht et al. 1987, Perry et al. 1989). Hanlon et al. (1989) suggested a conservative bait-density estimate for areas of high raccoon population density of 3 baits $/ \mathrm{ha}\left(300 / \mathrm{km}^{2}\right)$. However, lower bait densities of 0.7 baits/ha $(70 /$ $\mathrm{km}^{2}$ ) have been successful in Canada (Rosatte et al. 2001). Rosatte and Lawson (2001) suggest that $75 \mathrm{baits} / \mathrm{km}^{2}$ in a rural environment is sufficient to vaccinate a significant portion of a raccoon population. The current ORV project in the Appalachians distributes 0.75 baits/ha $\left(75 / \mathrm{km}^{2}\right)$. Reported raccoon density estimates for the Northeast are $10-20 \mathrm{raccoons} / \mathrm{km}^{2}$ in rural environments. Assuming a similar raccoon density on the MWERF, a bait density of $75 / \mathrm{km}^{2}$ would result in 7.5-3.8 baits per raccoon within the baited area. An estimated 2 raccoons $/ \mathrm{km}^{2}$ (our estimate was 1.5 raccoons $/ \mathrm{km}^{2}$ ) would result in approximately 37.5 baits per raccoon. The average homerange size for males was 394 ha. Assuming an average travel area, an individual raccoon could potentially contact 148 baits $\left(3.94 \mathrm{~km}^{2} \times 37.5\right.$ baits $)$ at the MWERF. Reducing bait densities to $50 / \mathrm{km}^{2}$ would still provide 25 baits per raccoon allowing surplus for non-target species while reducing the cost by $30 \%$. Although not tested, we also speculate that further reducing bait densities within the proposed parameters above would maintain a 70\% effective immunization rate while further reducing program costs.

\section{Acknowledgments}

Funding was provided by USDA Forest Service Northeastern Research Station, Division of Forestry, West Virginia University, Cooperative Fish and Wildlife Research Unit US Geological Survey, MeadWestvaco Corporation, USDA/APHIS Wildlife Services, and West Virginia Division of Natural Resources. We would like to thank our field technicians, H. Brace and J. Adams for their hard work and long hours. We also thank J. Johnson, J. Rodrigue, and J. Crum for field and laboratory assistance. 


\section{LITERATURE CITED}

Bacon, P. J. 1985. Population dynamics of rabies in wildlife. Academic Press, New York, New York. $358 \mathrm{pp}$.

Carey, A. B. 1985. Multispecies rabies in the Eastern United States. Pages 23-39 in P. J. Bacon, editor. Population dynamics of rabies in wildlife. Academic Press, New York, New York. 258 pp.

Davidson, W. R., and V. F. Nettles. 1997. Field manual of wildlife diseases in the Southeastern United States. Southeastern Cooperative Wildlife Disease Study. 417 pp.

Hable, C. P., A. N. Hamir, D. E. Snyder, R. Jouner, J. French, V. Nettles, C. Hanlon, and C. E. Rupprecht. 1992. Prerequisites for oral immunization of free-ranging raccoons (Procyon lotor) with a recombinant rabies virus vaccine: study site ecology and bait system development. Journal of Wildlife Diseases. 28:64-79.

Hanlon, C. L., D. E. Hayes, A. N. Hamir, D. E. Snyder, S. Jenkins, C. P. Hable, and C. E. Rupprecht. 1989. Proposed field evaluation of a rabies recombinant vaccine for raccoons (Procyon lotor): site selection, target species characteristics, and placebo baiting trials. Journal of Wildlife Disease. 25:555-567.

Hubbard, D. R. 1985. A descriptive epidemiological study of raccoon rabies in a rural environment. Journal of Wildlife Diseases. 21:105-110.

Johnson, S. A. 1970. Biology of the raccoon (Procyon lotor) in Alabama. Agricultural Experiment Station Auburn University Bulletin 402. 148 pp.

Kaufmann, J. H. 1982. Raccoon and Allies. Pages 567-585 in J. A. Chapman and G. A. Feldhamer, editors. Wild mammals of North America. John Hopkins University Press, Baltimore, Maryland. $1147 \mathrm{pp}$. 
Kramer, M. T., R. J. Warren, M. J. Ratnaswamy, and B. T. Bond. 1999. Determining sexual maturity of raccoons by external versus internal aging criteria. Wildlife Society Bulletin. $27: 231-234$.

Kreeger, T. J. 1996. Handbook of wildlife chemical immobilization. Wildlife Pharmaceuticals, Inc., Fort Collins, Colorado. 342 pp.

Lotze, J. H., and S. Anderson. 1979. Procyon lotor. Mammalian Species. 119:1-8.

Perry, B. D., N. Garner, S. R. Jenkins, K. McCloskey, and D. H. Johnston. 1989. A study of techniques for the distribution of oral rabies vaccine to wild raccoon populations. Journal of Wildlife Diseases. 25:206-217.

Rogers, R. 2000. West Virginia raccoon field trial survey 1999-2000. West Virginia Division of Natural Resources, Romney, West Virginia. $11 \mathrm{pp}$.

Rosatte, R. D. Donovan, M. Allan, L. Howes, A. Silver, K. Bennett, C. MacInnes, C. Davies, A. Wandeler, and B. Radford. 2001. Emergency response to raccoon rabies introduction into Ontario. Journal of Wildlife Diseases. 37:265-276.

Rosatte, R. C., and K. F. Lawson. 2001. Acceptance of baits for delivery of oral rabies vaccine to raccoons. Journal of Wildlife Diseases. 37:730-739.

Sikes, R. K. 1980. Rabies. Pages 3-17 in J. W. Davis, L. H. Karstad, and D. O. Trainer, editors. Infectious diseases of wild mammals, $2^{\text {nd }}$ edition. Iowa State University Press, Ames, Iowa. $446 \mathrm{pp}$.

Torrence, M. E., S. R. Jenkins, and L. T. Glickman. Epidemiology of raccoon rabies in Virginia, 1984 to 1989 . Journal of Wildlife Diseases. 28:369-376. 


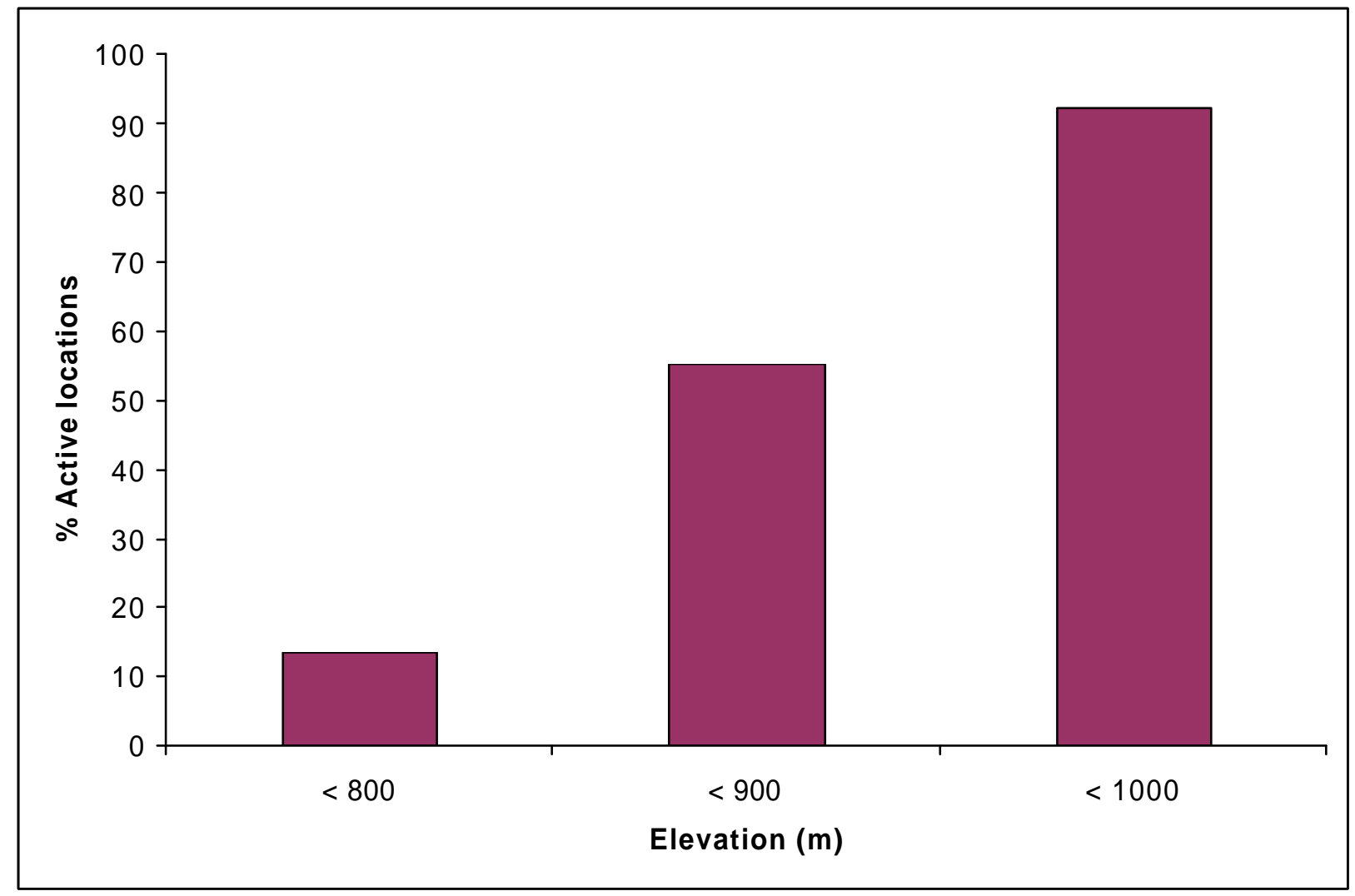

Figure 1. Percentage of nocturnal activity below elevational buffers of 800,900 , and $1000 \mathrm{~m}$ on the MeadWestvaco Wildlife and Ecosystem Research Forest, Randolph County, West Virginia, during 2001 to 2002. 


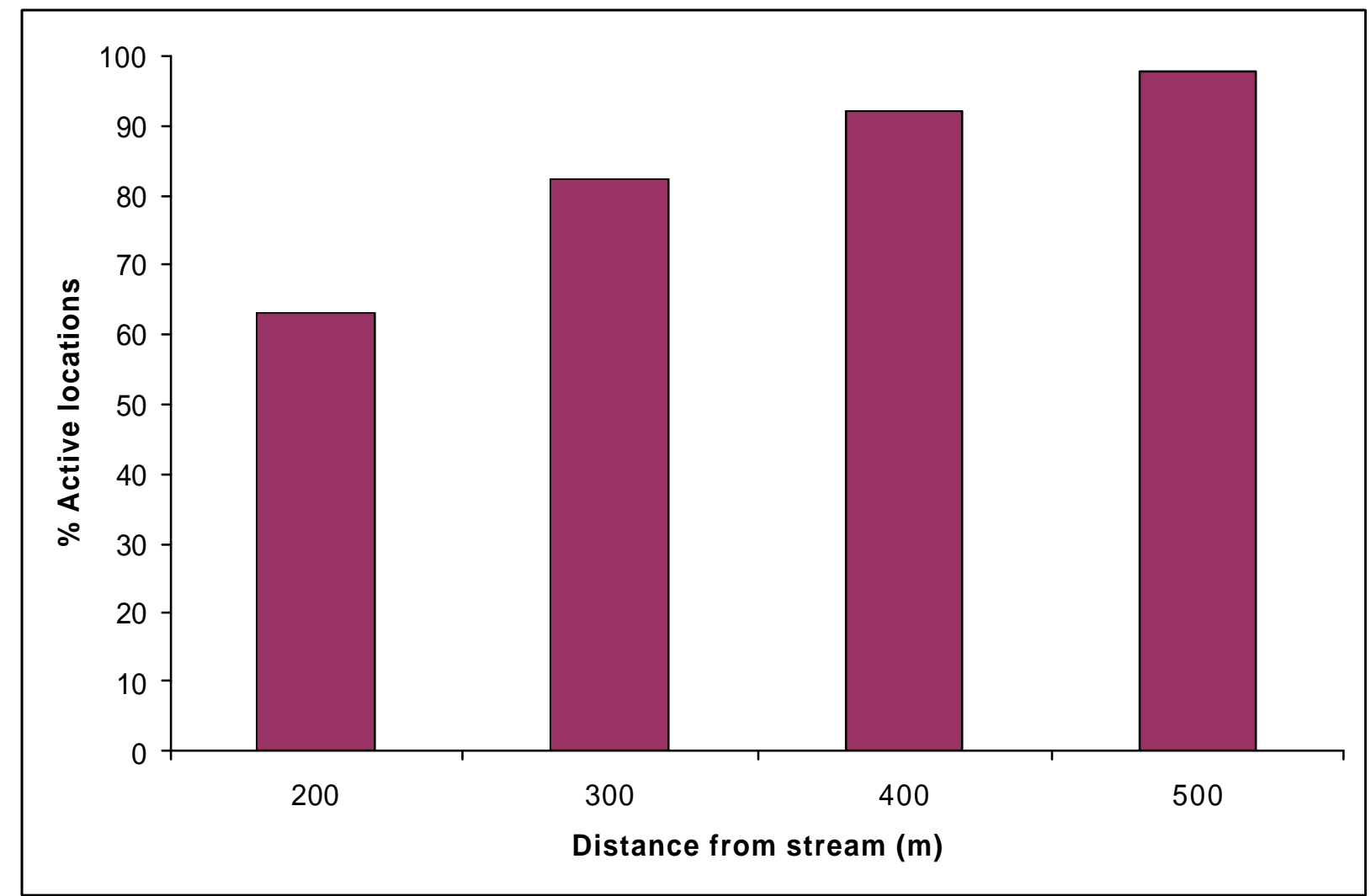

Figure 2. Percentage of nocturnal activity within stream buffers of 200, 300, 400, and $500 \mathrm{~m}$ on the MeadWestvaco Wildlife and Ecosystem Research Forest, Randolph County, West Virginia, during 2001 to 2002. 


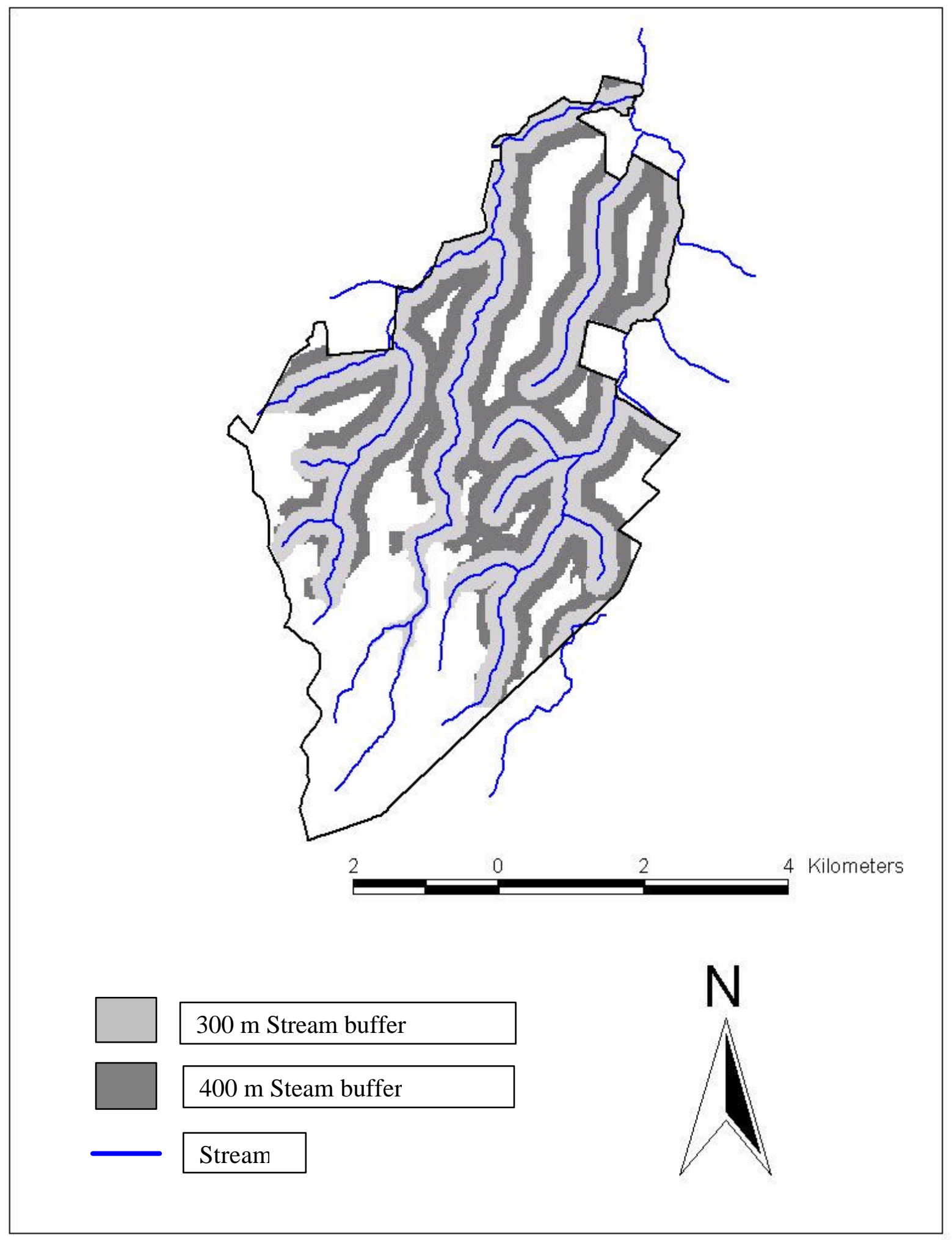

Figure 3. Targeted bait drop area within $300 \mathrm{~m}$ and $400 \mathrm{~m}$ of a stream and below $1000 \mathrm{~m}$ elevation on the MeadWestvaco Wildlife and Ecosystem Research Forest, Randolph County, West Virginia. 


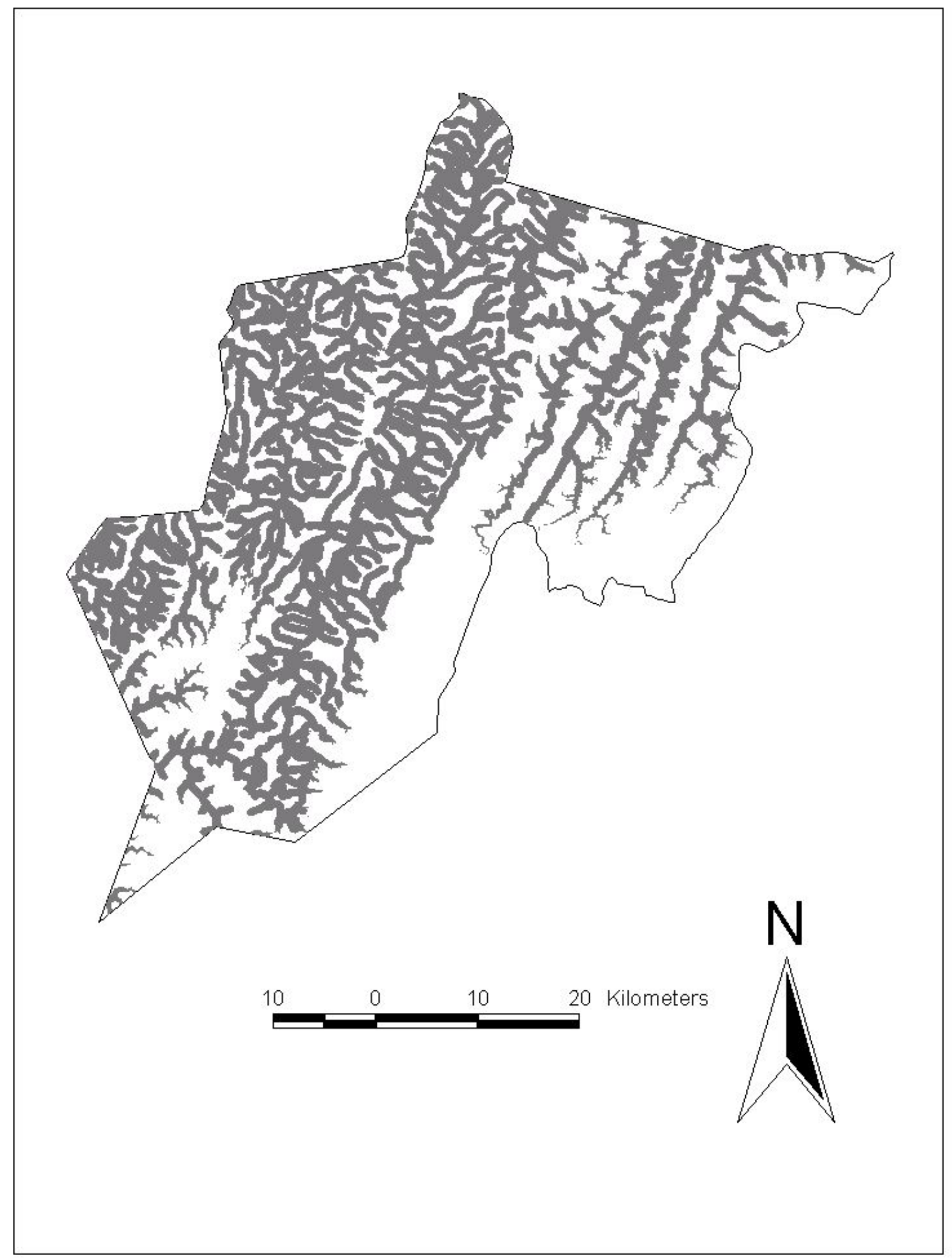

Figure 4. Targeted bait drop area within $400 \mathrm{~m}$ of a stream and below $1000 \mathrm{~m}$ elevation in Randolph County, West Virginia. 


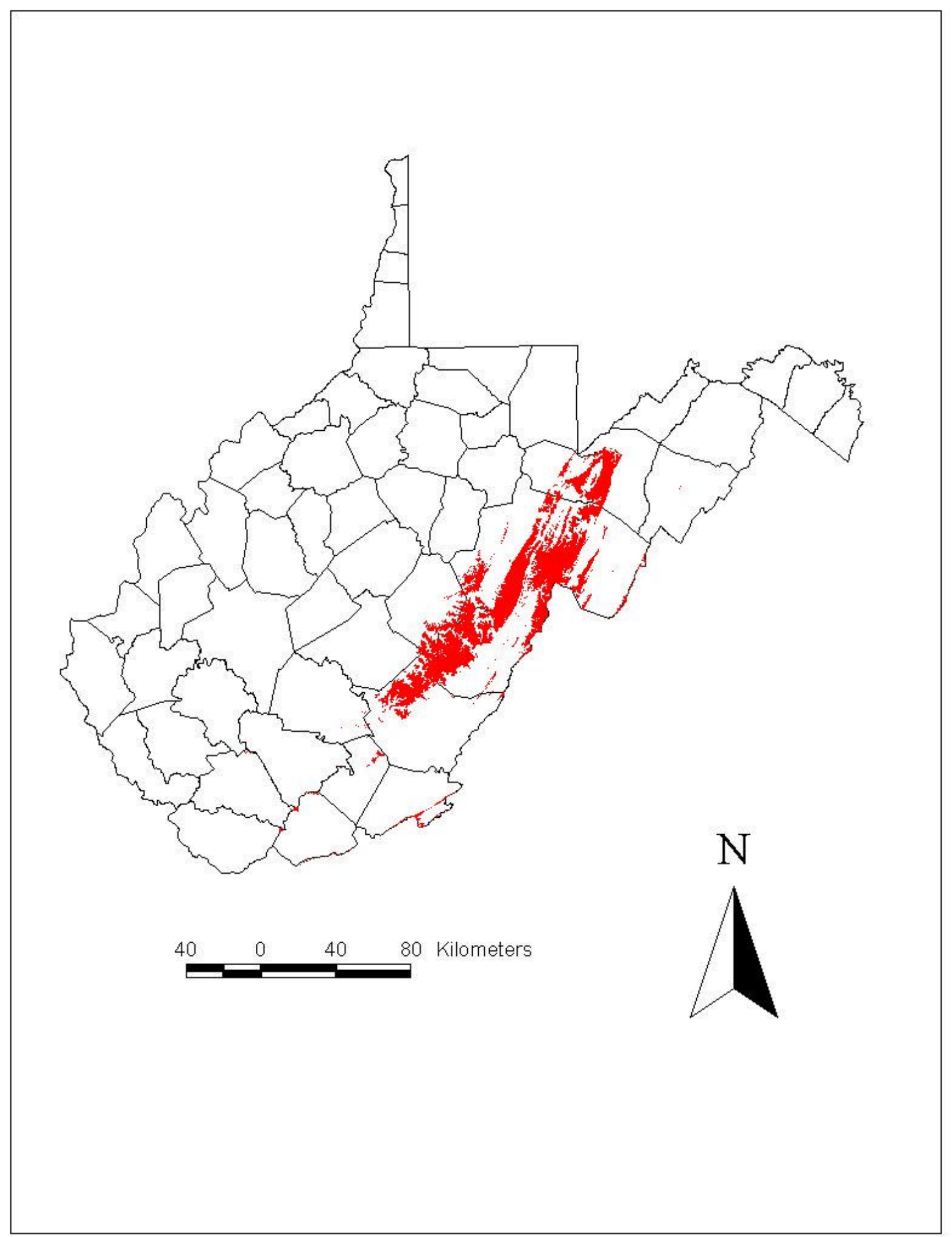

Figure 5. Area within the Allegheny Mountains of West Virginia greater than $1000 \mathrm{~m}$ elevation. 


\section{Chapter 5}

\section{CONCLUSIONS AND MANAGEMENT IMPLICATIONS}

Forest management can create habitat modifications that alter vertebrate species assemblages and disrupt species-habitat associations. Increased fragmentation and edge, along with other structural changes brought about by forestry practices, may enhance the abundance and predatory efficiency of raccoons and other medium-sized mammalian predators (Heske et al. 2001). This study focused on raccoon spatial ecology and the impacts of intensive forest management on raccoons in a northern Allegheny hardwood forest.

This region along the higher elevations of the Allegheny Mountains is considered poor raccoon habitat (Rogers 2000) mainly because of the near absence of agricultural crops, wetland or marsh areas, and human refuse. Because the Allegheny Mountain region is mostly forested habitat and a mast driven system, years of poor mast crops or mast failures can further decrease habitat quality and negatively impact raccoon populations. The apparent decline of oak species in regenerating stands (Lorimer 1992) may affect future raccoon populations and limit their abundance and distribution. Natural resource managers must promote hard-mast producing tree species (i.e., oak) in the overstory to maintain foraging resources for raccoons and other wildlife species.

As generalists, raccoons exhibit a diverse diet and show an ability to quickly respond to temporal and spatial changes in food resources and habitat disturbances. Because of these capabilities, raccoons can use a variety of habitat conditions and types. Raccoons on the MWERF selected intact riparian forests and regeneration harvests during summer and intact upland forests and diameter-limit harvests during fall. Regeneration harvests (>3 years old) provided patches of soft mast producing Rubus spp, particularly during summer. Black cherry 
mast is abundant within intact riparian-forest stands and relied upon by raccoons during late summer. These riparian areas also provide access to free water required by raccoons. Raccoons are commonly associated with water and their movements are restricted by proximity to free water (Johnson 1970, Lotze and Anderson 1979, Kaufman 1982). Both upland and riparianintact forest stands along with diameter-limit stands consist of hard mast producing species including red oaks and American beech, both of which are valuable fall mast producers.

Large diameter mast-producing tree species are not only required for forage resources but also for the production of tree cavities often selected as den sites, particularly by females during the maternal period. The selection of tree cavities by females during parturition indicates the importance of cavities in the hierarchy of required resources. In addition, tree cavity use, particularly by female raccoons, may explain the selection of intact riparian-forest vegetation types during summer. Furthermore, land managers should consider the retention of cavity trees within their management plans. Leaving intact forests in upland areas and along streams (riparian management zones) helps secure the presence of cavity trees while protecting watercourses for foraging areas and other wildlife species.

Intensive forest management within the central Appalachians creates a dilemma for raccoon ecology. The MWERF is managed on 20-80 year rotations where mature forests eventually will comprise only a small portion of the area. Increased reductions in large diameter trees may affect raccoon recruitment due to loss of suitable maternal cavities (Chapter 2) especially in stands on 20-40-year rotations. However, early successional stands in association with mature second- or third-growth forests provide a mosaic of habitats resulting in a spatial and temporal dynamic of foraging resources. Coincidently, regeneration harvests can produce seasonal foods on a temporary basis (3-10 years) while ensuring the regeneration of mast 
producing, shade intolerant tree species that have the potential to develop large-diameter tree cavities. Likewise, intact upland forest stands with larger diameter trees while potentially providing tree cavities and hard mast during fall months, may be of limited benefit to raccoons in summer. Forest management that combines the retention of large diameter overstory trees with intermediate thinnings to release the understory may meet foraging requirements during the summer while providing suitable cavity trees.

Among the types of harvest strategies used in West Virginia forests, approximately $80 \%$ are diameter limit harvests (Fajvan et al. 1998). Although the diameter-limit harvest is a common harvesting technique used on the MWERF and throughout the central Appalachians on private lands, the quality of the residual stand and provisions for its adequate regeneration are rarely considered. Repeated diameter-limit harvests, without regard to species composition, will shift forest composition to shade-tolerant species as well as degrade stand quality (Nyland 1996). Reduction in hard mast producing species (Quercus spp.) via diameter-limit harvests will eliminate an important food source during autumn and winter, further limiting food resources and raccoon abundance. Maintaining mature intact stands along with intermediate aged stands and newly harvested regeneration cuts would ensure a continuum of future large-diameter trees while allowing forest operations to continue. Forest managers can also provide potential cavity trees by managing for cavity prone species such as yellow-poplar, American beech, maples, and oak. Further research should be conducted on unmanaged forestlands within the mostly forested central Appalachians to determine importance of tree cavities and impacts on recruitment and raccoon abundance within an unmanaged forest system.

Recent Allegheny woodrat population declines in the northern and western peripheries of its range have been attributed in part to the fatal exposure to B. procyonis and to habitat loss 
from forest fragmentation (Birch et al. 1994, Balcolm and Yahner 1996). Current land use practices have altered raccoon spatial distribution. Therefore, land management practices may have forced or expanded raccoon populations into habitats occupied by Allegheny woodrats (Balcolm and Yahner 1996). Because the MWERF is an intensively managed forest, habitat fragmentation and the reduction in large-diameter tree cavities may result in increased raccoon and woodrat interaction. Our results ind icate that raccoon homeranges include areas of known Allegheny woodrat occupation and on several occasions, raccoons were found denning in rock outcrops that contained active woodrat colonies or signs of past use.

Raccoon roundworm prevalence on the MWERF is less than $8 \%$ if not zero. Therefore, the MWERF raccoon population is likely not negatively impacting woodrat populations via roundworm infection. Also, the low density and spatial dispersion of raccoons on the MWERF may reduce the likelihood of direct and indirect interactions between raccoons and woodrats, and therefore B. procyonis infection.

The westward spread of raccoon rabies in West Virginia has been much slower than the spread to the northeast, probably in response to lower raccoon populations in the Allegheny Mountains. These lower populations are due in part to unsuitable habitat within the higher elevations of the Allegheny Mountains (Rogers 2000). On our study site, elevations ranged from 600 to $1100 \mathrm{~m}$ with contrasting habitats of Allegheny hardwoods in the lower elevations and Eastern hemlock and red spruce forests in the highest elevations (> $1000 \mathrm{~m})$. Because of the absence of mast producing species at higher elevations, these habitats are least selected by raccoons. Raccoon activity was concentrated (92\%) below 1000 m elevation. Our results also indicate that most raccoon activity $(92 \%)$ was in proximity $(<400 \mathrm{~m})$ to perennial or intermittent streams. 
Our results further the understanding of raccoon spatial ecology in respect to forest management and add to the limited knowledge of raccoon movements within the higher elevations of the Allegheny Mountains. This study illustrates the need to retain large diameter tree cavities for use as dens, particularly as maternal dens. Our findings also indicate the need for a matrix of successional forest stages to meet raccoon foraging requirements on a seasonal basis. Finally, the results of this study should help refine the target area within the higher elevation Allegheny Mountains to successfully inoculate an effective portion of the raccoon population to produce population immunity.

Although much has been learned, there is still much to learn about raccoon ecology and management on a broader scale. Specifically:

(1) Studies investigating raccoon and Allegheny woodrat interactions on an unmanaged forested landscape;

(2) Increased surveillance of Baylisascaris procyonis across the state in areas of known raccoon and Allegheny woodrat sympatry; and

(3) Studies investigating effective baiting densities based on raccoon and non-target population densities.

\section{LITERATURE CITED}

Balcom, B. J., and R. H. Yahner. 1996. Microhabitat and landscape characteristics associated with the threatened Allegheny woodrat. Conservation Biology. 10:515-525.

Birch, G. L., G.A. Feldhamer, and W. G. Dyer. 1994. Helminths of the gastrointestinal tract of raccoons in Southern Illinois with management implications of Baylisascaris procyonis occurrence. Transactions of the Illinois State Academy of Science. 83:165-170.

Endres K. M., and W. P. Smith. 1993. Influence of age, sex, season and availability on den 
selection by raccoons within the Central Basin of Tennessee. American Midland Naturalist. 129:116-131.

Fajvan, M. A., S. T. Grushecky, and C. C. Hassler. 1998. The effects of harvesting practices on West Virginia's wood supply. Journal of Forestry. 96:33-39.

Heske, E. J., S. K. Robinson, and J. D. Brawn. 2001. Nest predation and neotropical migrant songbirds: piecing together the fragments. Wildlife Society Bulletin. 29:52-61.

Johnson, S. A. 1970. Biology of the raccoon (Procyon lotor) in Alabama. Agricultural Experiment Station Auburn University Bulletin 402. 148 pp.

Kaufmann, J. H. 1982. Raccoon and Allies. Pages 567-585 in J. A. Chapman and G. A. Feldhamer, editors. Wild mammals of North America. John Hopkins University Press, Baltimore, Maryland. 1147 pp.

Lorimer, C. G. 1992. Caused of the oak regeneration problem. Pages 14-33 in D. L. Loftis and C. E. McGee, editors. Oak regeneration: serious problems practical solutions. General Technical Report SE-84.

Lotze, J. H., and S. Anderson. 1979. Procyon lotor. Mammalian Species. 119:1-8

Nyland, R. D. 1996. Silviculture: Concepts and Applications. McGraw-Hill Series, Boston, Massachusetts. 633 pp.

Rogers, R. 2000. West Virginia raccoon field trial survey 1999-2000. West Virginia Division of Natural Resources, Romney, West Virginia. 11 pp. 